\title{
FNREL
}

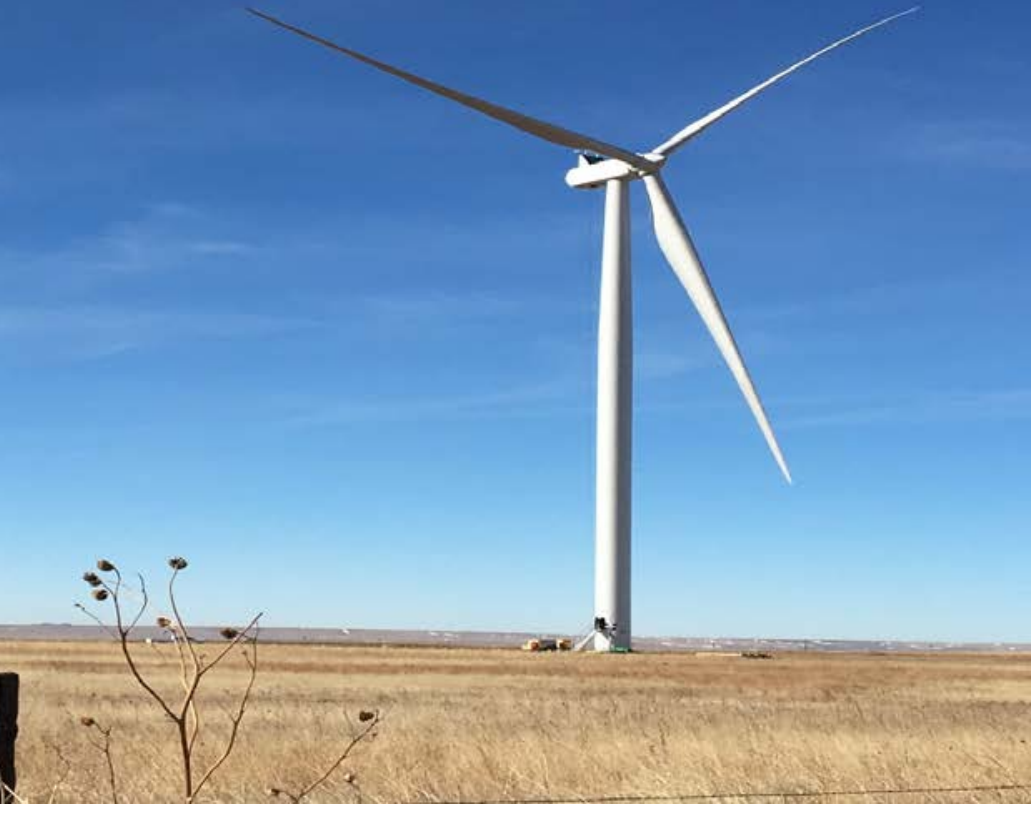

\section{Economic Impacts from Wind Energy in Colorado Case Study: Rush Creek Wind Farm}

Jeremy Stefek, ${ }^{1}$ Anna Kaelin, ${ }^{1}$ Suzanne Tegen, ${ }^{2}$ Owen Roberts, ${ }^{1}$ and David Keyser ${ }^{1}$

1 National Renewable Energy Laboratory

2 Colorado State University

NREL is a national laboratory of the U.S. Department of Energy Office of Energy Efficiency \& Renewable Energy

Operated by the Alliance for Sustainable Energy, LLC

This report is available at no cost from the National Renewable Energy Laboratory (NREL) at www.nrel.gov/publications.
Technical Report

NREL/TP-5000-73659

September 2019 


\title{
GNREL
}

\section{Economic Impacts from Wind Energy in Colorado Case Study: Rush Creek Wind Farm}

\author{
Jeremy Stefek, ${ }^{1}$ Anna Kaelin, ${ }^{1}$ Suzanne Tegen, ${ }^{2}$ \\ Owen Roberts, ${ }^{1}$ and David Keyser ${ }^{1}$ \\ 1 National Renewable Energy Laboratory \\ 2 Colorado State University
}

\section{Suggested Citation}

Stefek, Jeremy, Anna Kaelin, Suzanne Tegen, Owen Roberts, and David Keyser. 2019. Economic Impacts from Wind Energy in Colorado Case Study: Rush Creek Wind Farm. Golden, CO: National Renewable Energy Laboratory. NREL/TP-5000-73659.

https://www.nrel.gov/docs/fy19osti/73659.pdf.

NREL is a national laboratory of the U.S. Department of Energy Office of Energy Efficiency \& Renewable Energy Operated by the Alliance for Sustainable Energy, LLC

This report is available at no cost from the National Renewable Energy Laboratory (NREL) at www.nrel.gov/publications.

Contract No. DE-AC36-08GO28308
Technical Report NREL/TP-5000-73659

September 2019

National Renewable Energy Laboratory 15013 Denver West Parkway Golden, CO 80401 303-275-3000 • www.nrel.gov 


\section{NOTICE}

This work was authored by the National Renewable Energy Laboratory, operated by Alliance for Sustainable Energy, LLC, for the U.S. Department of Energy (DOE) under Contract No. DE-AC36-08GO28308. Funding provided by U.S. Department of Energy Office of Energy Efficiency and Renewable Energy Wind Energy Technologies Office. The views expressed herein do not necessarily represent the views of the DOE or the U.S. Government.

This report is available at no cost from the National Renewable Energy Laboratory (NREL) at www.nrel.gov/publications.

U.S. Department of Energy (DOE) reports produced after 1991 and a growing number of pre-1991 documents are available free via www.OSTI.gov.

Cover Photo by Suzanne Tegen, NREL 49999.

NREL prints on paper that contains recycled content. 


\section{Acknowledgments}

The authors are grateful to the U.S. Department of Energy (DOE) Wind Energy Technologies Office for funding and supporting this research and report. In particular, the authors thank Maggie Yancey, Patrick Gilman, Jocelyn Brown-Saracino, Rich Tusing, and Valerie Reed.

The authors would like to thank Tony Jimenez of the National Renewable Energy Laboratory (NREL) for help with modeling and analysis. We thank Adam Reed for his advisory role within the Masters of the Environment program at the University of Colorado at Boulder. We also appreciate Lydia Lawhon from the University of Colorado at Boulder for assistance with the interviewing process.

For their peer review, the authors thank Fiona Sigalla and Jason Peuquet of Colorado's Department of Regulatory Agencies. In addition, for their review, we thank Ian Baring-Gould, Eric Lantz, Brian Smith, and Daniel Laird of NREL. The authors are grateful for Ruth Baranowski and Sheri Anstedt's review and technical editing.

The authors are especially appreciative of the communities near the Rush Creek Wind Farmespecially Limon, Hugo, Simla, Matheson, Genoa, and Kiowa, Colorado. This report would not have been possible without the contributions from many community members, especially Melody Bolton, Haden Lamb, Jan Kochis, Troy McCue, Mark Orttel, James Russell, and Grant Thayer. The authors would also like to thank the individuals that contributed who wish to remain anonymous.

Finally, NREL appreciates the following organizations for their time and contributions:

- Vestas Wind Systems

- Aluwind Inc.

- Hexcel Corporation

- Lincoln County Economic Development Corporation

- Genoa RV Park

- Lincoln County, Colorado

- Elbert County, Colorado

- Cheyenne County, Colorado

- Kit Carson County, Colorado.

This work was authored by the National Renewable Energy Laboratory, operated by Alliance for Sustainable Energy, LLC, for the U.S. Department of Energy (DOE) under Contract No. DEAC36-08GO28308. Funding provided by the U.S. Department of Energy Office of Energy Efficiency and Renewable Energy Wind Energy Technologies Office. The views expressed in this document do not necessarily represent the views of the DOE or the U.S. Government. The U.S. Government retains and the publisher, by accepting the document for publication, acknowledges that the U.S. Government retains a nonexclusive, paid-up, irrevocable, worldwide license to publish or reproduce the published form of this work, or allow others to do so, for U.S. Government purposes. 


\section{List of Abbreviations and Acronyms}

AWEA

BOP

BVEM

DOE

FTE

GDP

GW

GWh

I-O

IMPLAN

JEDI

$\mathrm{kW}$

LCEDC

LCOE

MW

MWh

NREL

OEM

O\&M

PUC

WISDEM
American Wind Energy Association

balance of plant

Best Value Employment Metrics

U.S. Department of Energy

full-time equivalent

gross domestic product

gigawatt

gigawatt-hour

input-output

IMpact Analysis for PLANing

Jobs and Economic Development Impact

kilowatt

Lincoln County Economic Development Corporation

levelized cost of energy

megawatt

megawatt-hour

National Renewable Energy Laboratory

original equipment manufacturer

operation \& maintenance

Public Utility Commission

Wind-Plant Integrated System Design and Engineering Model 


\section{Executive Summary}

The 600-megawatt (MW) Rush Creek Wind Farm, owned and operated by Xcel Energy, is Colorado's largest wind energy project as of year-end 2018. This wind development spans four rural counties in eastern Colorado: Cheyenne, Elbert, Kit Carson, and Lincoln. The project is comprised of three hundred 2-MW Vestas turbines, primarily supplied from Vestas Colorado manufacturing facilities. Figure ES-1 shows the location of the Rush Creek Wind Farm relative to Vestas' Colorado manufacturing plants as well as the affected counties.

The statewide and four-county region jobs and economic impacts were modeled using the National Renewable Energy Laboratory's (NREL's) Jobs and Economic Development Impact (JEDI) tool. ${ }^{1}$ The results in Sections 3.1 and 3.3 provide national, state, and local stakeholders with data on the jobs, earnings, gross domestic product (GDP), and gross economic output supported by the Rush Creek Wind Farm (Rush Creek).

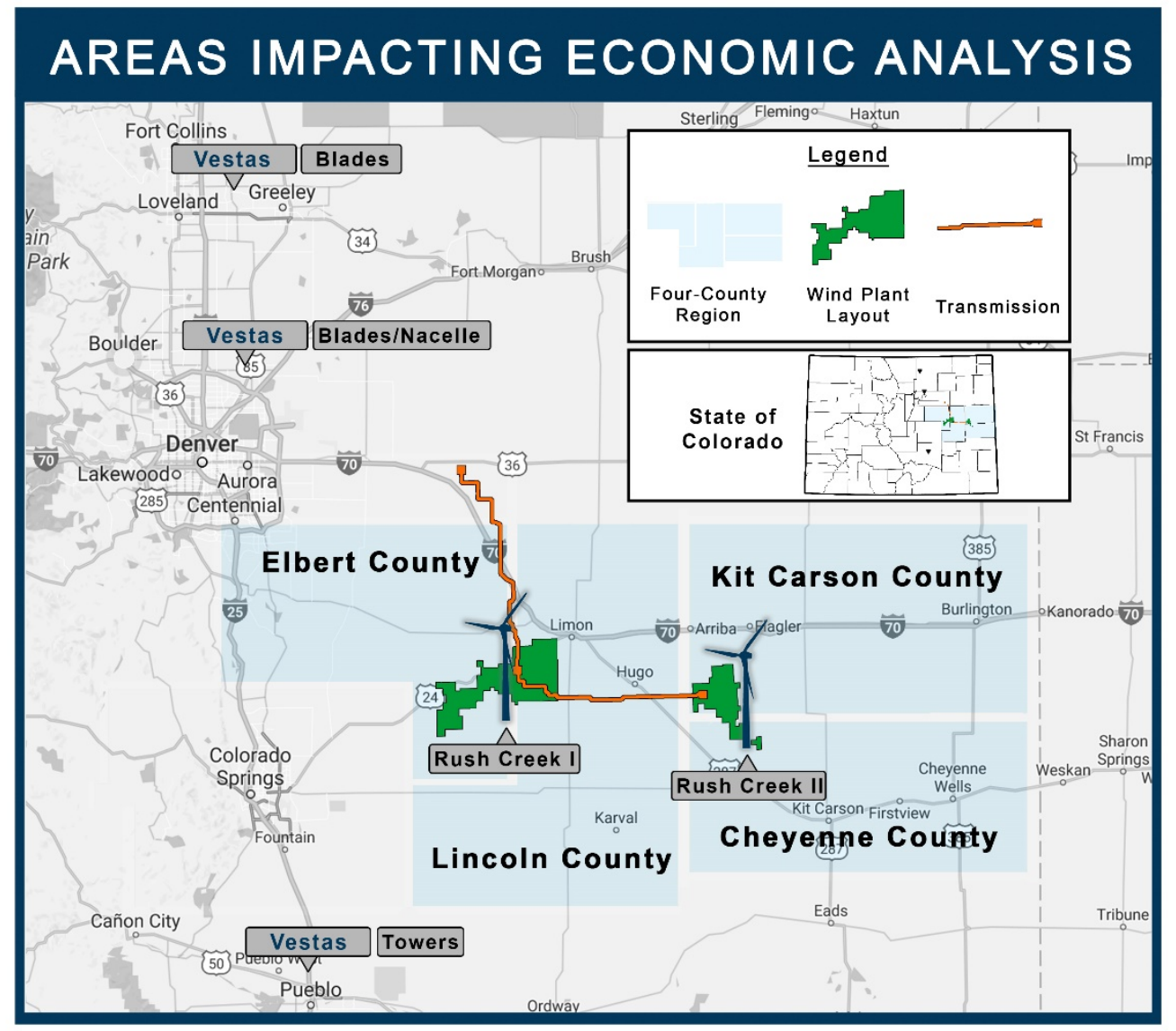

Figure ES-1. Map of the Rush Creek Wind Farm, Vestas manufacturing plants, and four-county region

\footnotetext{
${ }^{1}$ The JEDI model is a tool used to estimate some of the economic impacts of energy projects. JEDI calculates results in the form of jobs, earnings, and economic output in three categories: project development and on-site labor, local revenue and supply chain, and induced impacts. All publicly available JEDI models can be downloaded from https://www.nrel.gov/analysis/jedi/.
} 
A unique aspect of the Rush Creek project is that the wind turbine blades, towers, and nacelles were manufactured within Colorado facilities by Vestas Energy (Xcel Energy 2018a). This provides an opportunity to study the jobs and economic activity supported by wind energy's manufacturing and supply chain in Colorado, as detailed in Section 3.2. Despite the Rush Creek project being a unique wind manufacturing case specific to Colorado, other states can utilize these findings to better understand the economic impacts of in-state wind manufacturing.

Figure ES-2 outlines the economic impacts categories associated with wind development, including project development and on-site labor; local revenue, turbine, and supply chain; and induced impacts. The circle categories shown in ES-2 correspond to the economic impact results in ES-3 and ES-4, which demonstrate the multiplier effect spurred by wind development and investment. Quantitative results in this report are estimates for the gross jobs and economic impacts supported by the Rush Creek Wind Farm. Model inputs were collected qualitatively through interviews and quantitatively using state databases, national wind energy research, and the JEDI model, as detailed in Section 4.

\section{JEDI LAND-BASED WIND MODEL CATEGORIES}

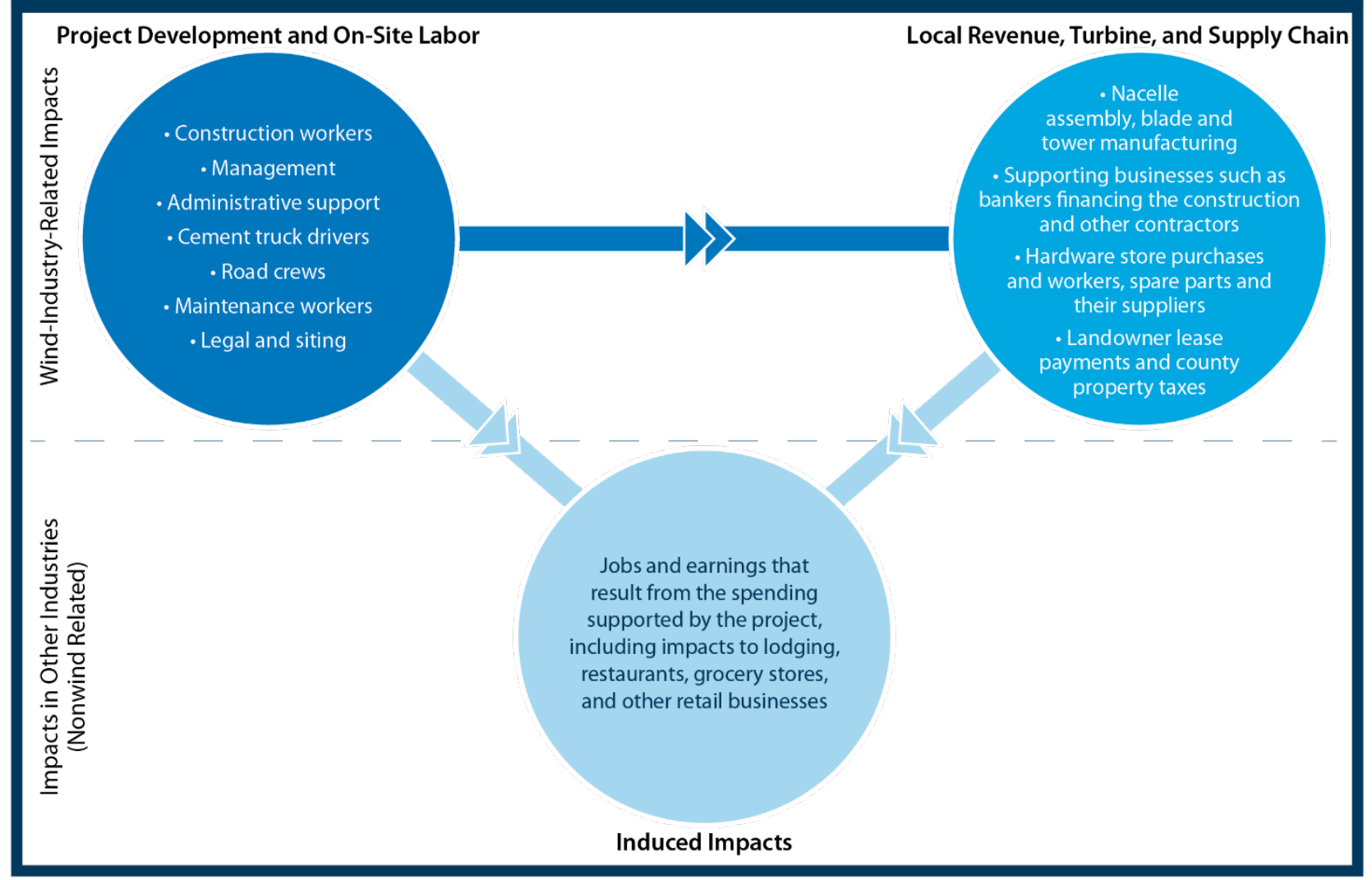

Figure ES-2. Land-based JEDI model economic impact categories 
Using empirical data, modeled data, and market research, NREL researchers developed a set of assumptions that represent the expenditures of the Rush Creek Wind Farm. Section 3.1 discusses these results in more detail. Based on the analysis, the Colorado statewide economic impacts from the 600-MW wind development are shown in Figure ES-3.

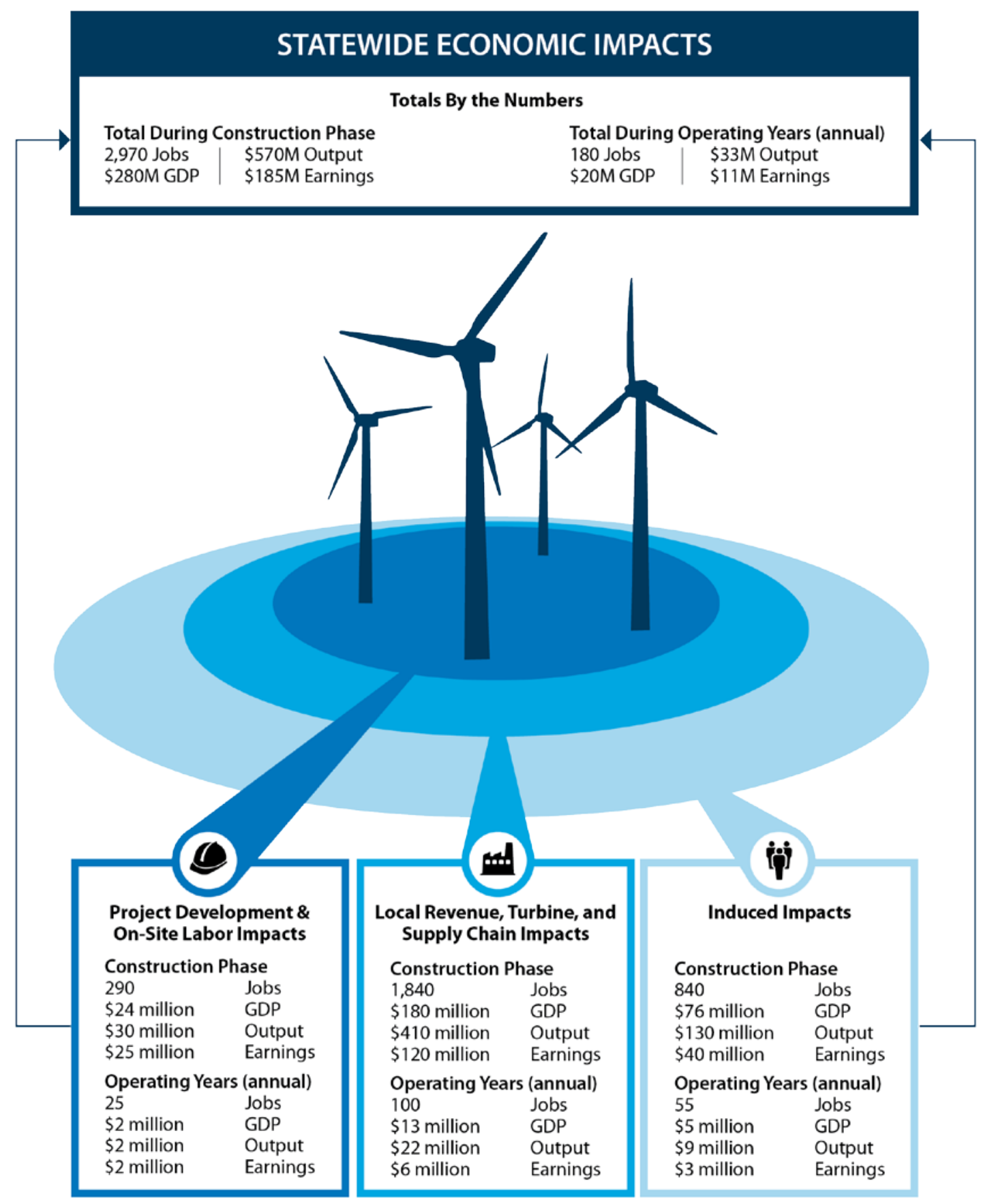

Figure ES-3. Summary of statewide economic impacts from the 600-MW Rush Creek Wind Farm supported during the construction phase and operating years

Additionally, the local economic impacts were estimated for the four-county region where the project was installed (see Figure ES-4). Section 3.3 discusses these results in more detail. 


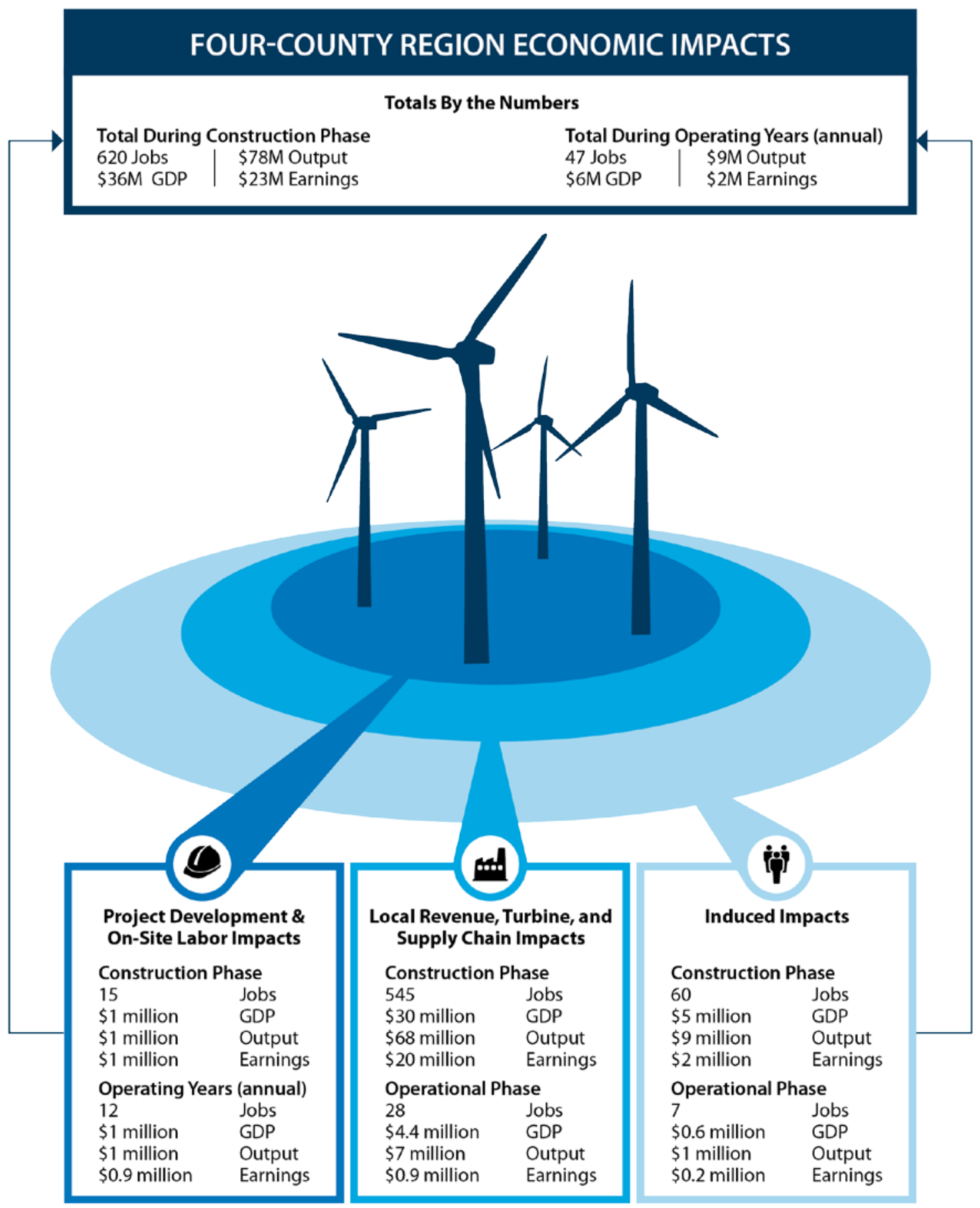

Figure ES-4. Summary of four-county region economic impacts from the 600-MW Rush Creek Wind Farm supported during the construction phase and operating years

Researchers also engaged with communities near the Rush Creek Wind Farm to collect empirical economic data as well as first-hand knowledge of community-level impacts during wind farm construction. Interviews were conducted with several community leaders and businesses. The themes from this qualitative research are summarized in Section 3.4 and in case studies 
throughout this report. By using both modeled and empirical data, the NREL team developed an informed picture of the economic impacts of wind energy development in rural Colorado. This qualitative research can educate other communities across America as they consider future wind development.

Researchers interviewed 39 local community members including business owners, managers, employees, county commissioners, and economic development office representatives. Interviews provided insight into on the ground effects on the local people and the economy. The interview methodology is detailed in Section 2.2 and Section 4.3. Most interviewees stated that the Rush Creek Wind Farm is one of the reasons business had increased over the past year. In summary:

- Approximately $67 \%$ of responding businesses experienced increases in revenue from the previous year, with $11 \%$ seeing significant additional revenue. Of these businesses, $58 \%$ selected Rush Creek as one of the factors contributing to revenue growth.

- Around $28 \%$ of respondents hired new people in the past year. Of these businesses, $80 \%$ attributed Rush Creek construction as one of the factors contributing to the need for new hiring.

- Approximately 56\% of employees worked more hours than last year. Of these businesses, $60 \%$ attributed increased hours worked to Rush Creek construction.

- Although we were not able to secure a random scientific sample, structured interview respondents expressed support for wind development in their community. Of respondents, $50 \%$ strongly support wind development, around 22\% moderately support wind development, and $28 \%$ were neutral. No respondents interviewed were opposed or strongly opposed to wind development in their communities.

Although interviewees were supportive of wind development, many reported several challenges from wind farm construction stemming from the influx of temporary workers to their communities. These challenges include a shortage of local housing and increased housing prices, a lack of lodging infrastructure to house temporary workers, an inability for some local businesses to keep up with increased demand, and a small pool of qualified local candidates from which to hire.

Even in the face of these challenges, based on the interviews conducted in the community, local businesses and business development organizations support wind construction. Lincoln and Elbert Counties, which host the majority of the Rush Creek turbines, are using fees and tax revenue from the Rush Creek Wind Farm for community revitalization and to put in a contingency fund to help buffer potential economic downturn effects. Grant Thayer, an Elbert County commissioner, hopes that funds from wind development will prevent future local government layoffs that have occurred previously in times of economic downturn. Restaurants and lodging are especially impacted by the influx of workers, assisting with Rush Creek's approximately 18-month construction phase. A restaurant owner reported he needed to double his weekend workforce. An RV park owner reported his spots were filled with Rush Creek workers. 
Wind development also supports landowners in the form of land lease payments to those who host a wind turbine on their property. Land lease payments can support dual income opportunities for farmers and ranchers. As Elbert County resident Jan Kochis explains, "Landowners with turbines on their property can still farm and ranch. The additional income from wind turbines helps keep people on their farms, even in the face of low yield or commodity prices."

By considering the reported results, rural communities can be more informed and prepared to maximize local economic benefits of future wind development and address the challenges.

In summary, this report is a quantitative and qualitative analysis of a single wind development: the 600-MW Rush Creek Wind Farm. ${ }^{2}$ The results highlight the jobs and economic activity supported during wind construction, manufacturing, and operation and maintenance activities. The case studies and qualitative research in this report provide context for the quantitative JEDI model results_-describing the economic impacts to rural communities.

\footnotetext{
2 This report was written so each section would convey all of the necessary information. As a result, readers may
} notice redundancies throughout this report. 


\section{Table of Contents}

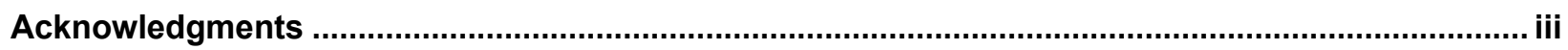

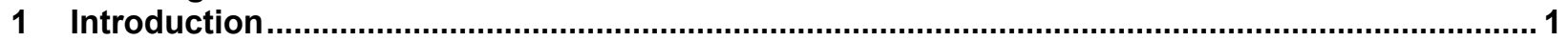

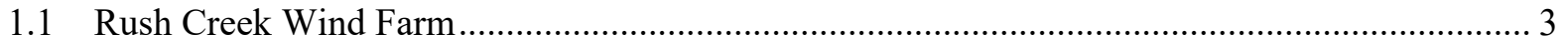

1.2 Domestic Manufacturing, Domestic Jobs, and Rural Gains..................................................... 5

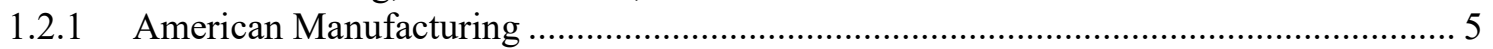

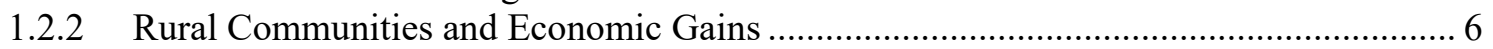

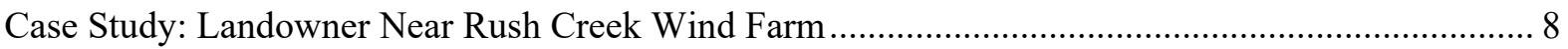

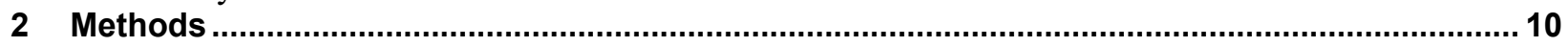

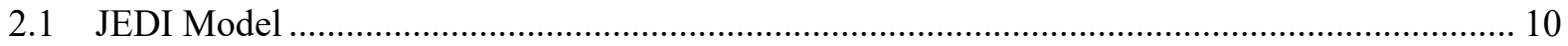

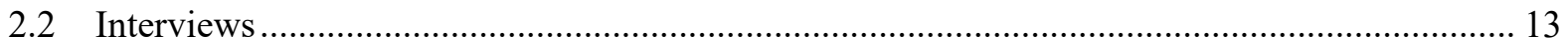

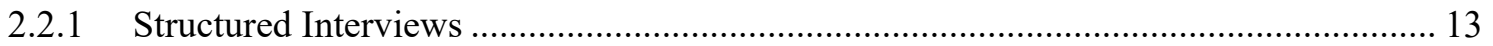

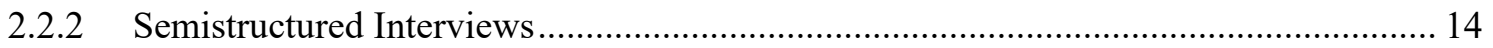

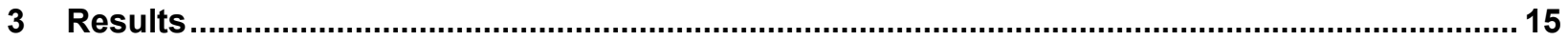

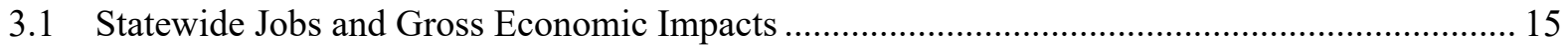

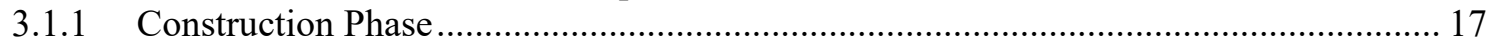

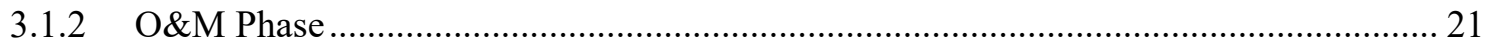

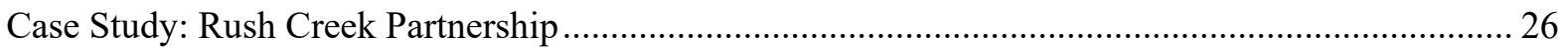

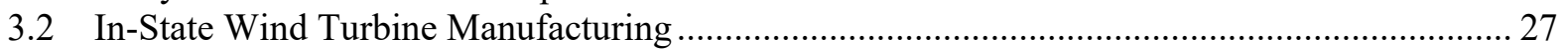

3.2.1 Colorado's Manufacturing and Supply Chain............................................................ 29

3.2.2 State-Level Manufacturing Jobs Supported from Rush Creek Turbines......................... 32

3.2.3 State-Level Manufacturing GDP Supported from Rush Creek Turbines....................... 33

3.2.4 Four-County Region Manufacturing Economic Impacts ............................................ 34

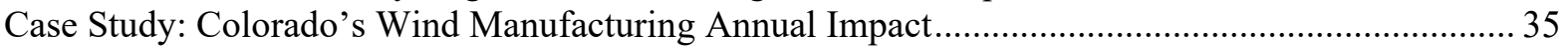

3.3 Four-County Region Jobs and Economic Impacts ........................................................... 36

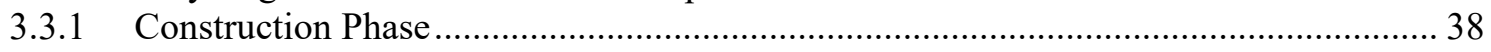

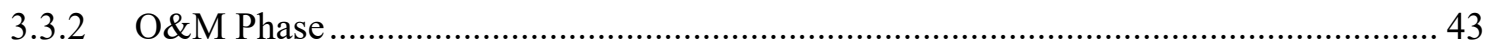

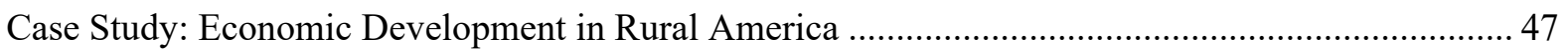

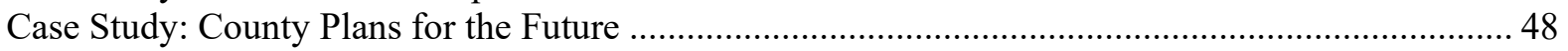

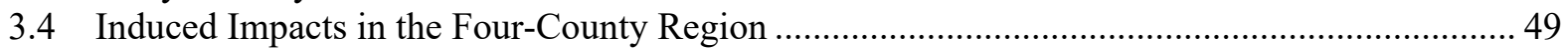

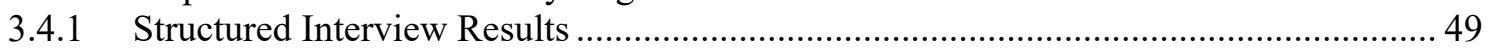

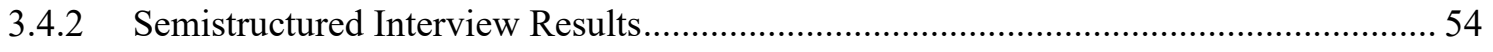

Case Study: Genoa RV Park, Supporting the Wind Industry and Rural America ..............................57

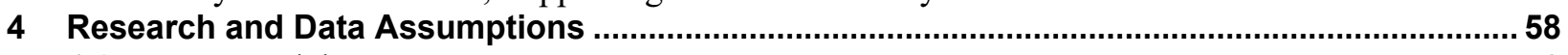

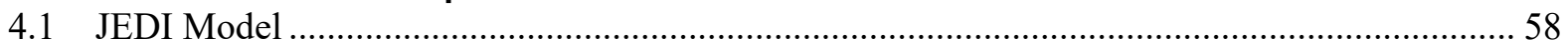

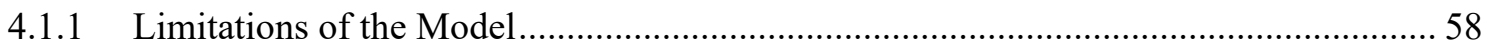

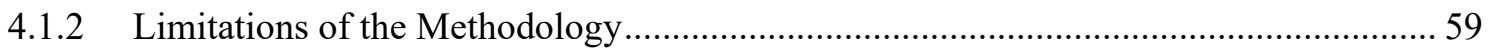

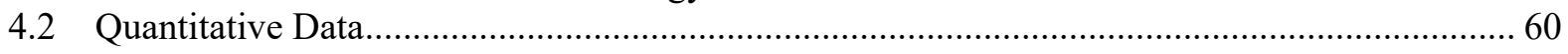

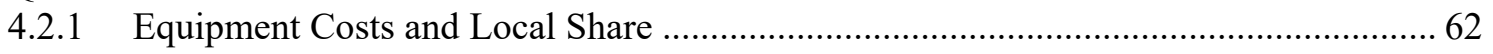

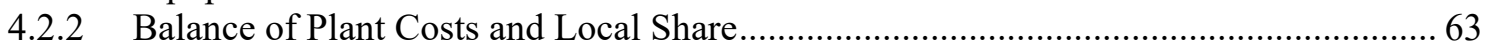

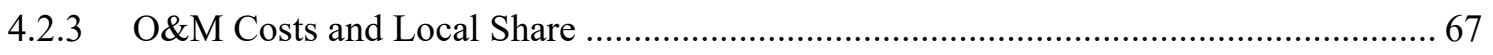

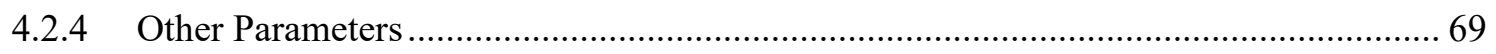

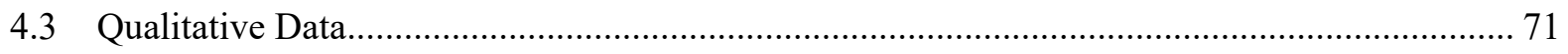

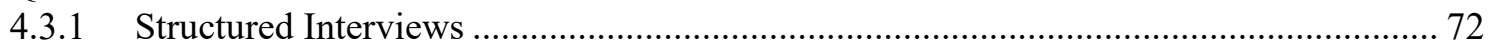

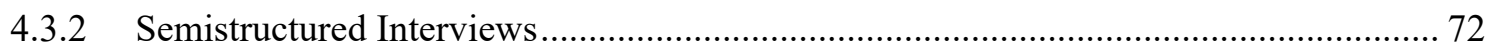

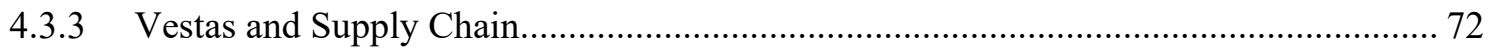

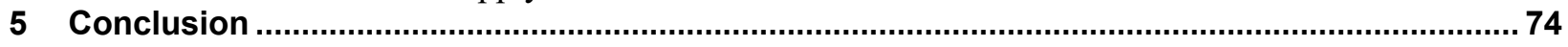

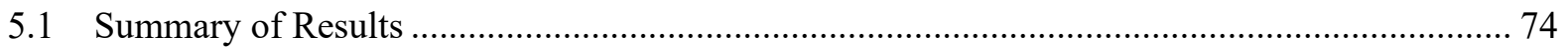

5.2 Maximizing Economic Development from Wind Energy .................................................... 75

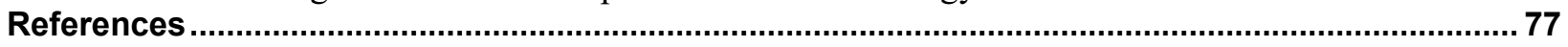




\section{List of Figures}

Figure ES-1. Map of the Rush Creek Wind Farm, Vestas manufacturing plants, and four-county region... v

Figure ES-2. Land-based JEDI model economic impact categories ........................................................ vi

Figure ES-3. Summary of statewide economic impacts from the 600-MW Rush Creek Wind Farm

supported during the construction phase and operating years............................................ vii

Figure ES-4. Summary of four-county region economic impacts from the 600-MW Rush Creek Wind

Farm supported during the construction phase and operating years ..................................viii

Figure 1. Annual and cumulative growth in U.S. wind power capacity (in gigawatts [GW]) ................... 1

Figure 2. Map of the Rush Creek Wind Farm, Vestas manufacturing plants, and four-county region ........ 3

Figure 3. Vestas wind turbine at the Rush Creek Wind Farm in January 2018..................................... 4

Figure 4. Wind turbine manufacturing site at the Vestas plant in Pueblo, Colorado.................................. 5

Figure 5. A Rush Creek wind turbine during construction at dusk............................................... 6

Figure 6. Virgil and Jan Kochis host Rush Creek turbines on their land.................................................. 8

Figure 7. Examples of the three categories in the JEDI model ........................................................... 12

Figure 8. State-level economic multiplier effect from the 600-MW Rush Creek Wind Farm.................... 16

Figure 9. At the state level, the 600-MW Rush Creek Wind Farm construction phase supported

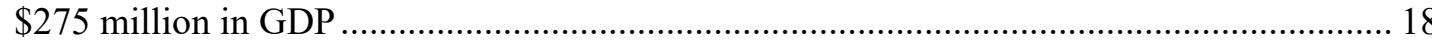

Figure 10. At the state level, the 600-MW Rush Creek Wind Farm construction phase supported $\$ 570$

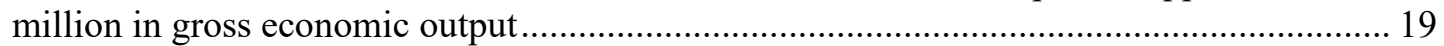

Figure 11. Statewide estimated job impacts supported from the wind plant construction phase................20

Figure 12. At the state level, Rush Creek is estimated to support \$20 million in GDP annually during

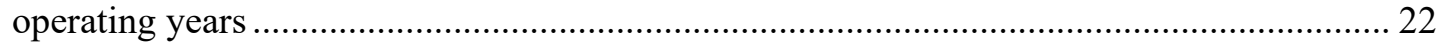

Figure 13. At the state level, Rush Creek is estimated to support $\$ 33$ million in gross economic output

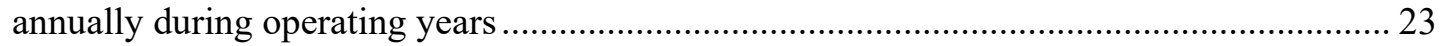

Figure 14. Statewide estimated jobs supported from Rush Creek during operating years ........................ 24

Figure 15. Map of Colorado's Rush Creek Wind Farm (locations I and II) and wind turbine

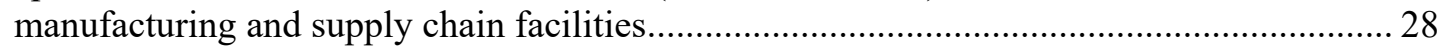

Figure 16. Colorado statewide wind turbine manufacturing and supply chain economic impacts supported

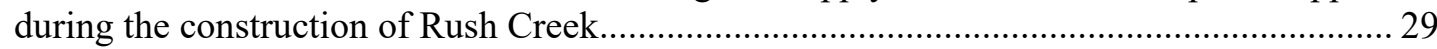

Figure 17. Number of jobs supported from wind turbine manufacturing and supply chain based in Colorado from Vestas wind turbines installed at Rush Creek, assuming $\$ 800 / \mathrm{kW}$ wind turbine cost

Figure 18. GDP supported from wind turbine manufacturing and supply chain based in Colorado from Vestas wind turbines installed at Rush Creek, assuming $\$ 800 / \mathrm{kW}$ wind turbine cost........... 33

Figure 19. Colorado statewide wind turbine manufacturing and wind-related supply chain impacts from

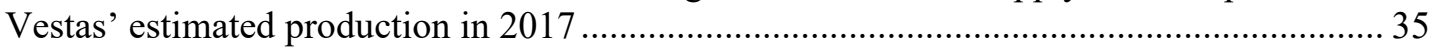

Figure 20. Four-county region economic impacts from the 600-MW Rush Creek Wind Farm ................. 37

Figure 21. In the four-county region, the 600-MW Rush Creek Wind Farm construction phase supported $\$ 36$ million in GDP

Figure 22. In the four-county region, the 600-MW Rush Creek Wind Farm construction phase supported

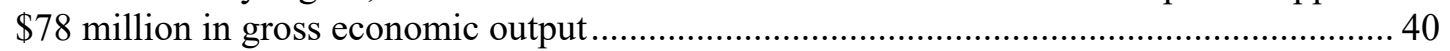

Figure 23. Four-county region Rush Creek Wind Farm construction materials expenditures................... 41

Figure 24. Four-county-region estimated jobs supported from Rush Creek construction ......................... 42

Figure 25. In the four-county region, Rush Creek is estimated to support \$6 million in GDP annually

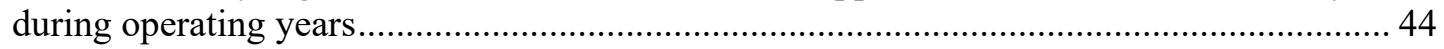

Figure 26. In the four-county region, Rush Creek is estimated to support $\$ 9$ million in gross economic

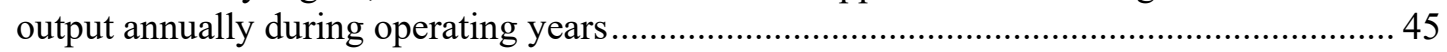

Figure 27. Four-county-region estimated annual ongoing jobs supported from Rush Creek O\&M.......... 46

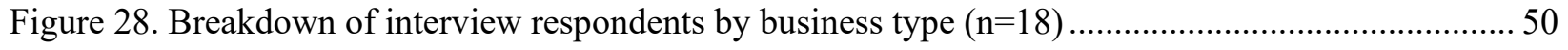


Figure 29. Lincoln County businesses hiring practices over the course of 1 year (during the Rush Creek Wind Farm construction)

Figure 30. Workloads of Lincoln County businesses over the course of 1 year (during the Rush Creek

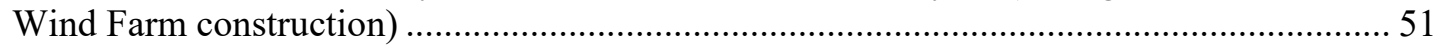

Figure 31. Lincoln County business revenue over the course of 1 year (during the Rush Creek Wind Farm

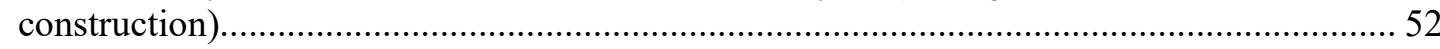

Figure 32. Lincoln County business owners/managers expected business growth in the next 12 months and the Rush Creek Wind Farm's impact on their businesses ............................................. 52

Figure 33. Lincoln County business owners'/managers' opinions of wind development in their community and how the local economy has changed in the past year (during the Rush Creek

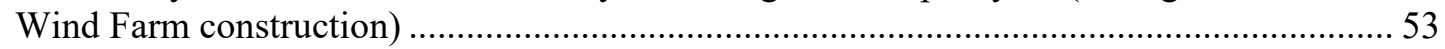

Figure 34. Additional structured interview comments from Limon business owners/managers ............... 54

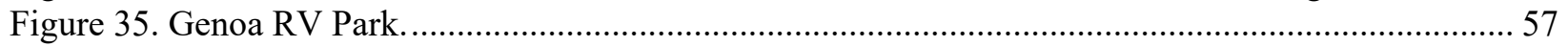

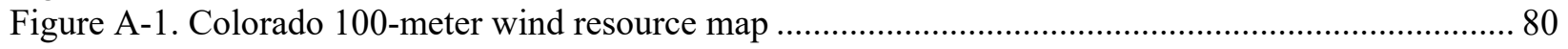

\section{List of Tables}

Table 1. Project Costs Overview for the Rush Creek Wind Farm ....................................................... 10

Table 2. Summary State-Level Economic Impact Estimate from the Rush Creek Wind Farm.................. 17

Table 3. Estimated Statewide Average Earnings for Workers During Wind Plant Construction................ 21

Table 4. Estimated Statewide Annual Earnings for Workers During Rush Creek O\&M phase .................25

Table 5. Percentage of Costs Spent In-State To Manufacture Wind Turbines in Colorado ....................... 29

Table 6. Vestas Manufacturing Plant Data for Colorado-Based Facilities .............................................. 30

Table 7. Vestas Wind-Related Manufacturing and Supply Chain Locations in Colorado.......................... 31

Table 8. Four-County-Region Rush Creek Construction Contractors .................................................... 41

Table 9. Estimated Four-County Region Average Earnings for Workers During Construction ................ 43

Table 10. Estimated Four-County Region Average Earnings for Workers During O\&M.........................46

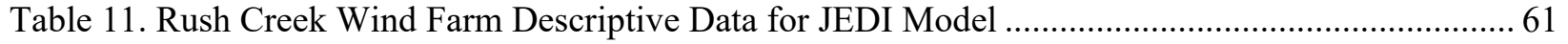

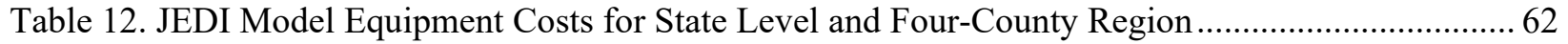

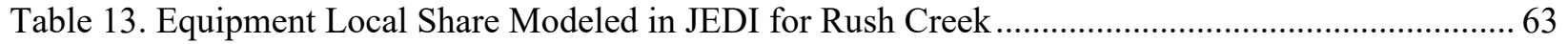

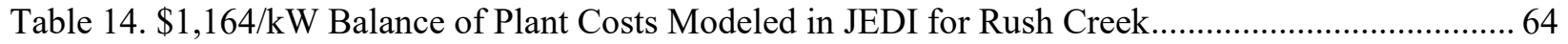

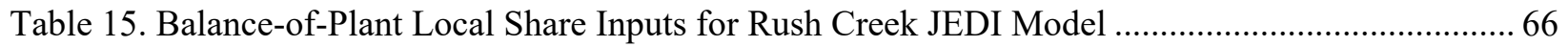

Table 16. JEDI O\&M Costs $(\$ 43.60 / \mathrm{kW})$ for Rush Creek at the State Level and Four-County Region ... 67

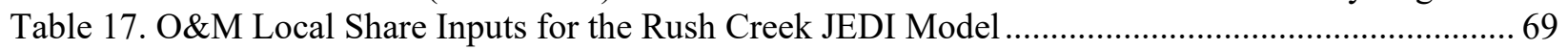

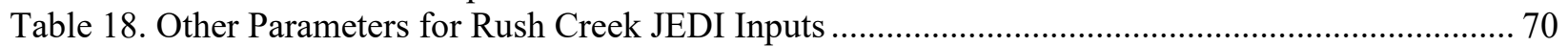

Table 19. Rush Creek Payroll Parameters for Construction and O\&M Labor ......................................... 71

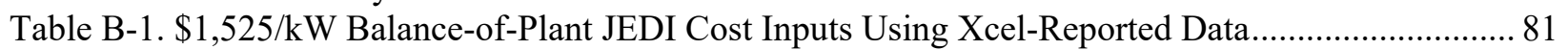

Table B-2. \$43.60/kW O\&M JEDI Cost Inputs Using Xcel-Reported Data ........................................... 82

Table C-1. State-Level Rush Creek JEDI Model Results: Xcel Energy-Reported Costs ........................... 83

Table D-1. Four-County Level Rush Creek JEDI Model Results: Xcel Energy-Reported Costs................ 84

Table E-1. Percentage of Material Expenditures Spent in Colorado ......................................................... 85

Table E-2. Percentage of Total Blade Expenditures Spent in Colorado ................................................ 86

Table E-3. Percentage of Tower Material Expenditures Spent in Colorado............................................. 86

Table E-4. Percentage of Total Tower Expenditures Spent in Colorado ................................................ 86

Table E-5. Percentage of Total Nacelle Expenditures Spent in Colorado ................................................ 87 


\section{Introduction}

State and local economies throughout America experience the effects of wind development through landowner payments, property and county tax revenue, and wind-related jobs. ${ }^{3}$ As more wind power is deployed in the United States, fully understanding these economic impacts is essential for communities, local businesses, and decision makers.

U.S. electricity served by renewables, particularly wind and solar, has more than doubled since 2008. Hydropower, wind, and solar generation accounted for approximately $17 \%$ of U.S. electricity generation in 2017 (Energy Information Administration [EIA] 2018a). Domestic wind energy generation is projected to continue growing. Colorado has been mirroring this trend as statewide renewable energy installed capacity and generation steadily increase. In Colorado, electricity generation from renewables has more than doubled since 2010 (EIA 2018b). In 2017, approximately $25 \%$ of the state's electricity generation was served by renewables, including hydropower. Approximately 18\% came from wind (EIA 2018b). Figure 1 demonstrates the increasing U.S. wind capacity trend. Colorado wind capacity is included in the interior region.

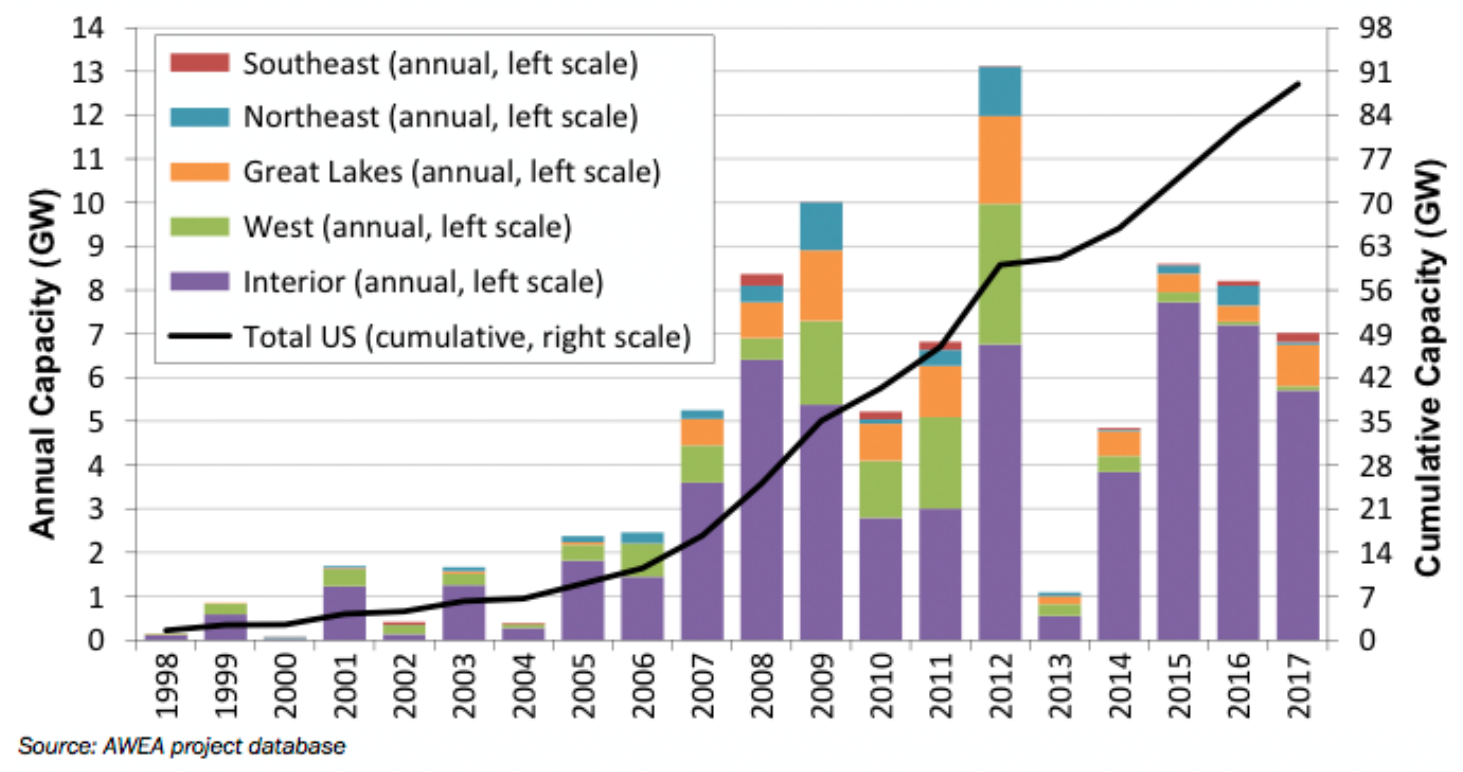

Figure 1. Annual and cumulative growth in U.S. wind power capacity (in gigawatts [GW]) Source: Wiser and Bolinger (2018)

Numerous conditions drive wind energy development in Colorado. The strong wind resource on the eastern plains provide a compelling homegrown energy source for the state. A map of Colorado's wind energy potential at a 100-meter (m) hub height is shown in Appendix A. Plotting the locations of Colorado's existing wind plants to Colorado's wind resource map

\footnotetext{
${ }^{3}$ This report does not cover economic benefits to Colorado residents from reduced externalities costs resulting from wind power, such as reduced healthcare costs. An analysis estimating the effects from this clean energy resource on Colorado's land, water, and animals is outside the scope of this research.
} 
indicates that from an available resource perspective there are opportunities for additional wind development.

Colorado has a renewables portfolio standard that requires investor-owned utilities to generate $30 \%$ of their electricity from renewable energy by $2020 .{ }^{4}$ By the second quarter of 2017 , Colorado's installed wind capacity reached 3,106 megawatts (MW), the ninth highest in the United States (Wiser and Bolinger 2018). Xcel Energy, the state's largest investor-owned utility, is on track to exceed Colorado's renewable energy requirement, due in part to wind projects such as the Rush Creek Wind Farm (Public Service Company of Colorado [PSCo] 2017c). In December 2018, Xcel Energy announced a clean energy vision to deliver 100\% carbon-free electricity to customers by 2050 (Xcel Energy 2018b).

Favorable economics play a large role in renewable energy development, and the cost to build and operate renewable energy projects is decreasing in Xcel Energy's service territory and throughout the country. The average installed project cost of wind energy in the interior region is $\$ 1,550 /$ kilowatt $(\mathrm{kW})$, a decrease of more than $\$ 830 / \mathrm{kW}$ since 2010 (Wiser and Bolinger 2018). At the end of 2017, Xcel Energy released a summary of 430 historically low bids received during the 2016 Colorado Electric Resource Plan solicitation. ${ }^{5}$ Wind-only bids had a median cost of \$18/megawatt-hour (MWh) (PSCo 2017b). When comparing wind energy to other generation technologies, wind has a competitive unsubsidized levelized cost of energy ranging from \$29/MWh to $\$ 56 / \mathrm{MWh}$, without considering geography dispatch characteristics or societal and environmental considerations (Lazard 2018).

Colorado has a high concentration of energy employment, with approximately 25,000 people working in electric power generation ${ }^{6}$ (Energy Futures Initiative [EFI] and National Association of State Energy Officials [NASEO] 2018). ${ }^{7}$ Solar has the highest employment related to electric power generation, supporting approximately $8,000 \mathrm{jobs}^{8}{ }^{8}$ This is followed by wind with more than 7,000 jobs (EFI and NASEO 2018). Employment in clean energy continues to grow in Colorado, increasing for the twelfth year in a row in 2017, nearly doubling the employment base size since 2007 (Metro Denver Economic Development Corporation 2017).

\footnotetext{
${ }^{4}$ Colorado's renewables portfolio standard can be seen here. Large cooperatives (greater than 100,000 customers) are required to provide $20 \%$ of their generation mix from renewables, and small cooperatives (fewer than 100,000 customers) and municipalities must provide 10\% renewable electricity (Database of State Incentives for Renewables and Efficiency 2015).

${ }^{5}$ Xcel Energy's Colorado Electric Resource Plan is a competitive solicitation process for new renewable energy projects. The median price for wind-plus-battery storage was $\$ 21 / \mathrm{MWh}$.

${ }^{6}$ According to the U.S. Energy and Employment Report (EFI and NASEO 2018), electric power generation employment includes "all utility and non-utility employment across electric generating technologies including fossil fuels, nuclear, and renewable energy technologies..." https://www.usenergyjobs.org/.

${ }^{7}$ Employment is tracked using current labor market data from the Bureau of Labor Statistics Quarterly Census of Employment and Wages.

${ }^{8}$ Refers only to direct, rather than indirect or induced, jobs. EFI and NASEO define a direct job as "created by the firm specific to the industry, while indirect jobs support these firms via supply or contracting services. Induced jobs are a result of the economic impact of direct and indirect employees spending their earnings."
} 
This report estimates the jobs and economic impacts of the 600-MW Rush Creek Wind Farm (hereafter referred to as "Rush Creek"). ${ }^{9}$ Economic impacts are estimated at both the state and four-county region level.

\subsection{Rush Creek Wind Farm}

Figure 2 shows the location of the Rush Creek Wind Farm in eastern Colorado, including the four counties that are part of the regional economic analysis. The wind plant is comprised of three hundred 2-MW Vestas turbines, manufactured or assembled in Colorado facilities (Xcel Energy 2017b). The three Vestas manufacturing locations are also shown in Figure 2.

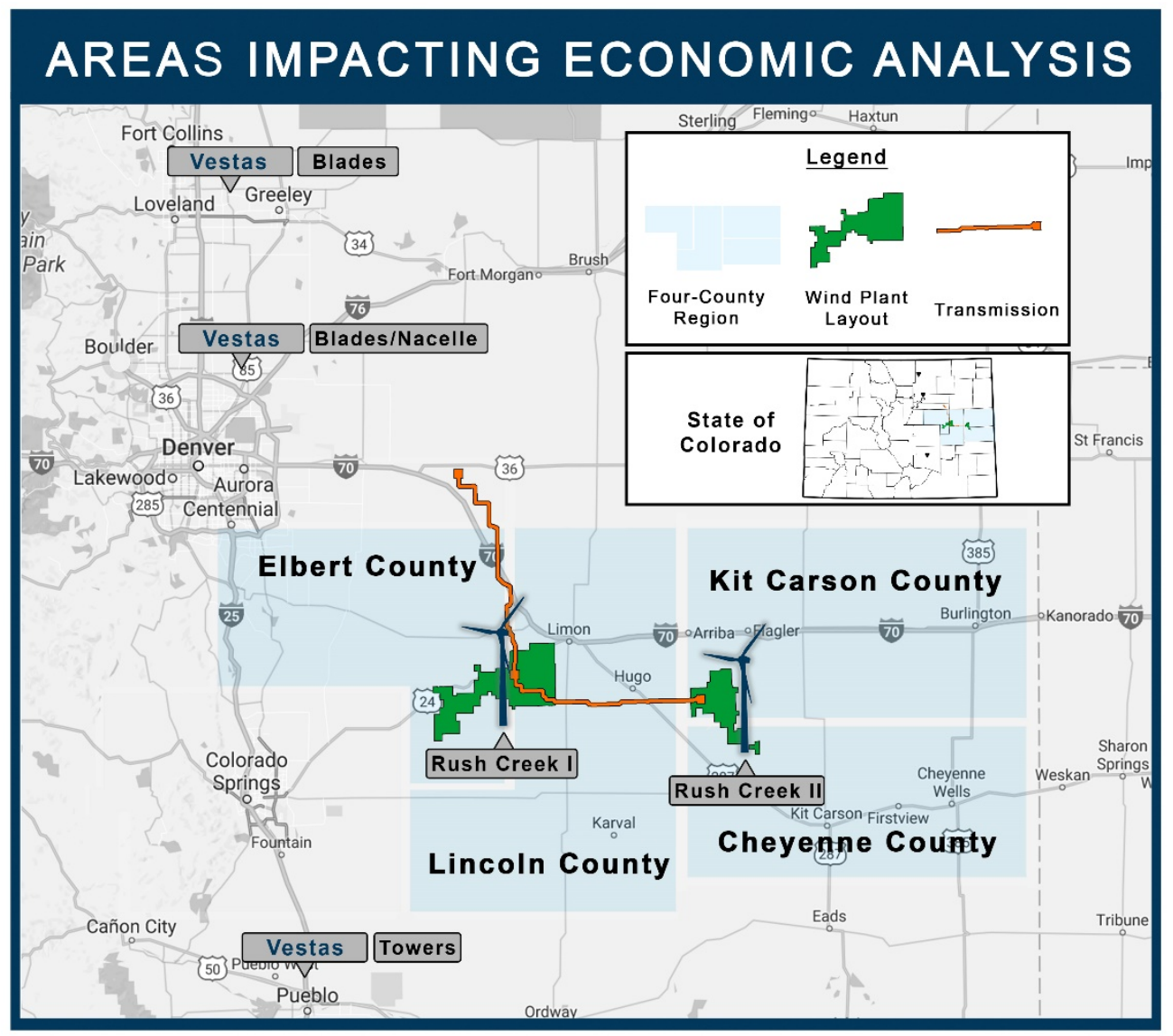

Figure 2. Map of the Rush Creek Wind Farm, Vestas manufacturing plants, and four-county region

Rush Creek is owned and operated by Colorado's largest utility, Public Service Company of Colorado (PSCo), a wholly owned subsidiary of Xcel Energy Inc. ${ }^{10}$ For simplicity, this report refers to PSCo as its parent company, Xcel Energy. The project was developed by Invenergy LLC., with the engineering, procurement, and construction fulfilled by Mortenson Construction.

\footnotetext{
${ }^{9}$ This report was written for each section to convey all the necessary information so readers may notice redundancies throughout.

${ }^{10}$ Xcel Energy is a Minnesota-based utility, which includes the operations of four wholly owned subsidiaries: Northern States Power Company-Minnesota, Northern States Power Company-Wisconsin, Public Service Company of Colorado, and Southwestern Public Service Company. Xcel Energy operates in eight states: Colorado, South Dakota, North Dakota, Minnesota, Wisconsin, Michigan, Texas, and New Mexico.
} 
The project was simultaneously built in two phases, spanning an area of more than 95,000 acres in Cheyenne, Elbert, Kit Carson, and Lincoln Counties of Colorado.

The construction project includes 83 miles of transmission that connect Rush Creek to Xcel Energy's Missile substation in Arapahoe County. This economic impact research focuses on wind energy development; the economic effects of the transmission line are outside the scope of the report. According to Xcel Energy, Rush Creek is projected to produce enough electricity to power 325,000 homes (Xcel Energy 2017a).

The farthest Vestas plant is approximately 150 miles away from Rush Creek in Windsor, Colorado. Wind turbine components for Rush Creek were delivered by truck instead of heavy rail. Typically rail is used for out-of-state installations. Using an in-state manufacturer decreased transportation time and costs for Rush Creek. Manufacturing and installing these Vestas wind turbines in the same state increased the economic impacts to Colorado. However, as explained in the following sections, although the wind turbine components are manufactured in Colorado, some parts and materials are sourced from out of state. For example, the nacelles are assembled in Colorado, but the subcomponents within the nacelles (e.g., generators, electronics) are not manufactured in Colorado.

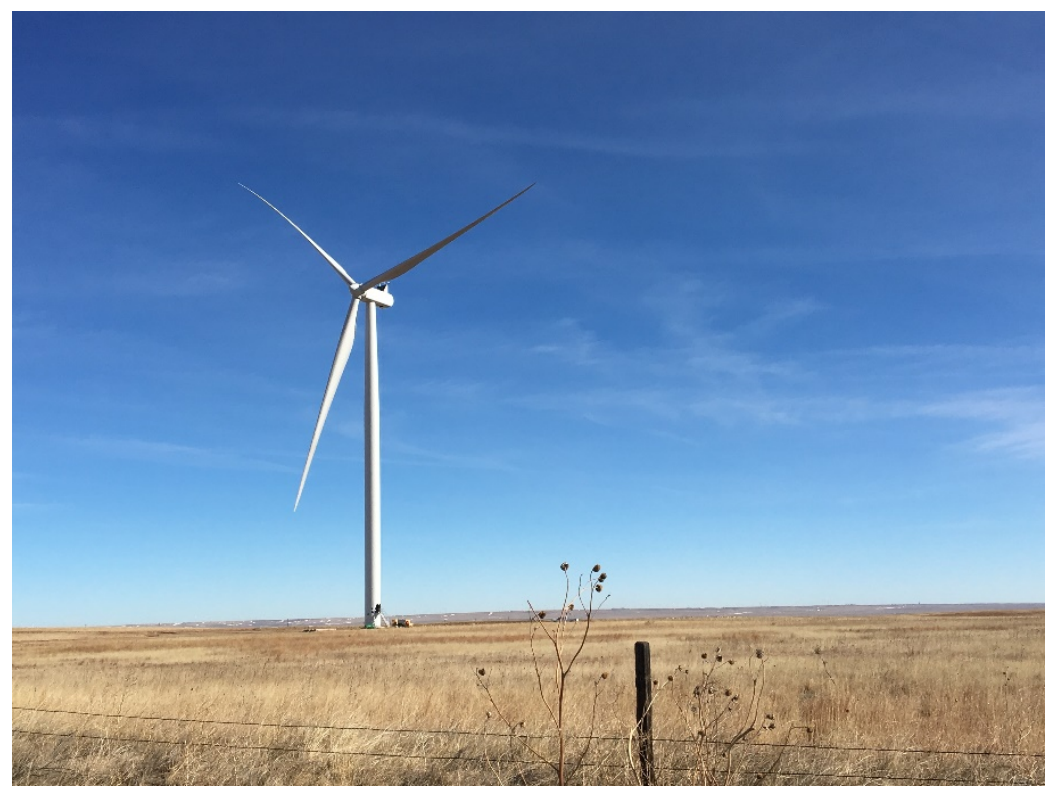

Figure 3. Vestas wind turbine at the Rush Creek Wind Farm in January 2018.

Photo by Suzanne Tegen, NREL 49999 


\subsection{Domestic Manufacturing, Domestic Jobs, and Rural Gains}

\subsubsection{American Manufacturing}

Wind turbine manufacturing supports economic development, such as jobs for highly skilled workers. As of 2017, wind energy supported more than 23,000 domestic factory jobs (American Wind Energy Association [AWEA] 2017b). ${ }^{11}$

Vestas Wind Energy in Colorado (see Figure 4) manufactures wind turbine towers in Pueblo and blades in Windsor and Brighton, and assembles nacelles in Brighton. Vestas employs approximately 3,500 people in these Colorado plants, ${ }^{12}$ including steady craft (e.g., welders, electricians, engineers) and assembly jobs, which represent most workers, followed by administrative and supervisor jobs.

The presence of an original equipment manufacturer (OEM) in Colorado attracted suppliers to the state. Internal component suppliers, such as Aluwind, Hexcel, and Creative Foam, opened operations in Colorado to co-locate near Vestas, supporting more jobs and industry in the state.

In typical American wind energy projects, turbine manufacturing occurs outside the state where the project is located, and the economic development from in-state manufacturing is not realized.

Research suggests that the greatest variable affecting wind energy's state and local economic impact is the supply of equipment (wind turbines), which generally constitutes $65 \%$ to $85 \%$ of a project's total costs. This makes local manufacturing the single largest driver of jobs and economic output in wind development (Lantz and Tegen 2008). The economic multiplier effect in Colorado is larger than is typical during wind development because the in-state production and installation of wind turbines supports jobs and economic activity in the manufacturing and supply chain as well as induced impacts, with plant workers living and spending earnings in their nearby communities.

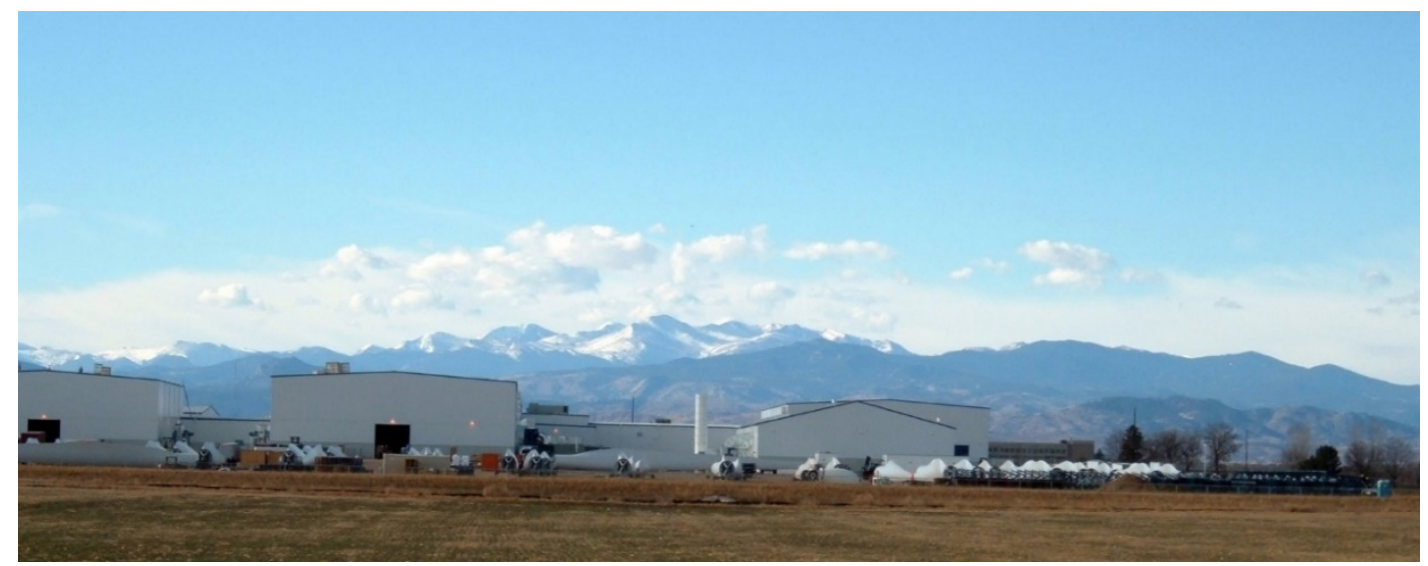

Figure 4. Wind turbine manufacturing site at the Vestas plant in Pueblo, Colorado. Photo by Frank A. Oteri, NREL 16017

\footnotetext{
${ }^{11}$ AWEA tracks and reports U.S. wind industry employment in terms of full-time-equivalents (FTEs).

12 Employment data based on interviews with Vestas.
} 


\subsubsection{Rural Communities and Economic Gains}

Wind energy projects provide employment and other economic impacts to an increasing number of rural communities across the country. Impacts include tax revenue for local governments, lease payment revenue for local farmers and ranchers, short-term construction jobs, and longterm operation and maintenance (O\&M) jobs often paying more than $\$ 64,000 /$ year. ${ }^{13}$

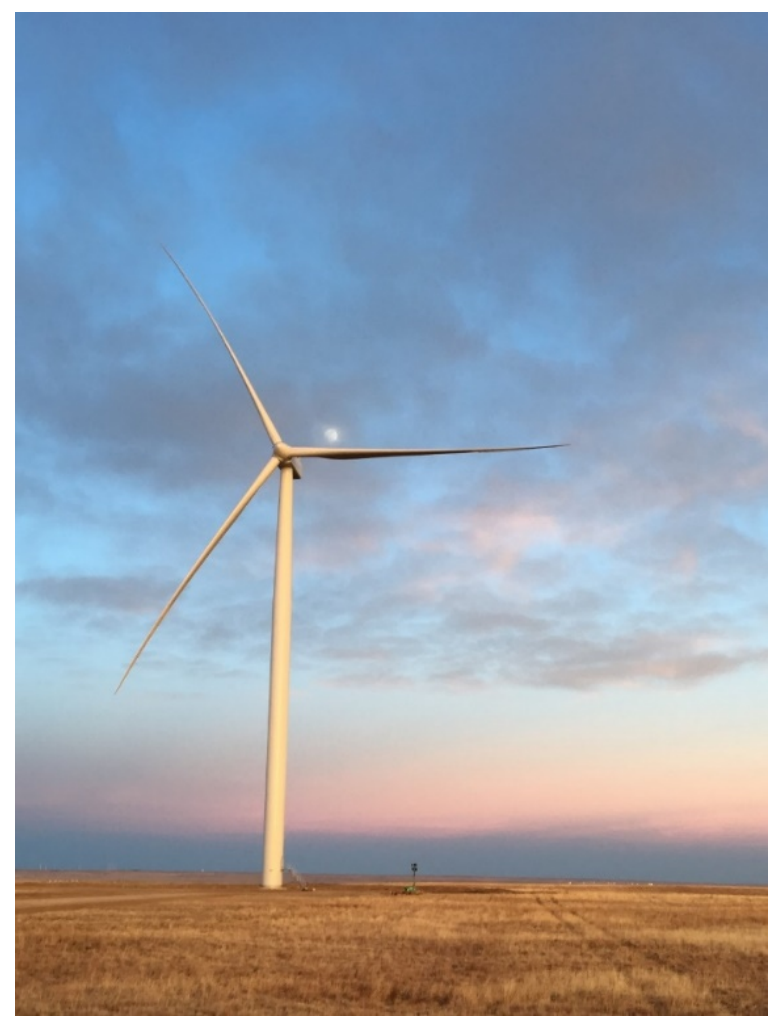

Figure 5. A Rush Creek wind turbine during construction at dusk.

Photo by Suzanne Tegen, NREL 50001

In 2016, landowners from all wind power plants in Colorado received between $\$ 10$ million and $\$ 15$ million in annual land lease payments from wind projects (AWEA 2019). Based on the data collected, the Rush Creek project will provide an estimated $\$ 45$ million $^{14}$ in landowner lease payments over a 25 -year lifetime. Lease payments provide extra income to landowners and can help farmers and ranchers maintain financial stability when commodity prices are low or bad weather hits the region. Although landowner agreements may differ, anecdotal data indicate that they are often based on a percentage of gross sales; in the case of Rush Creek, the percentage earned by the landowner increases during the lifetime of the project.

The Rush Creek project will also provide approximately $\$ 62.5$ million in property taxes during its 25 -year life. ${ }^{15}$ Property tax revenues from wind projects in eastern Colorado have provided

\footnotetext{
${ }^{13}$ Rush Creek O\&M wages are approximately $9.5 \%$ higher than the average annual wage in the four-county region and $12.4 \%$ higher than the average annual wage in Colorado. Wages are based on JEDI model results.

${ }^{14}$ Land lease payments based on an interview with a landowner with Rush Creek turbines on their property.

${ }^{15}$ Property tax revenue based on Xcel Energy's Best Value Employment Metrics report.
} 
funding for schools, libraries, and fire departments (E2 2018). Elbert County, which hosts 190 of the 300 turbines installed for Rush Creek, is estimated to receive the highest property tax revenues each year.

According to regional interviews, the affected counties are also receiving millions of dollars in one-time building permit fees and/or sales and use taxes from wind development. Counties are using tax revenues from Rush Creek to fund community revitalization and infrastructure projects. Counties are also appropriating wind farm revenue for times of economic downturn and emergencies, strengthening the long-term sustainability of their communities, according to local sources.

Wind development supports long-term local O\&M jobs throughout the life of the project. As detailed in this report, economic impacts from wind O\&M jobs have a multiplier effect as workers spend earnings at local businesses near wind farms. Case studies and interview results indicate that wind energy development can help agricultural communities increase their employment base and maintain economic stability during times of economic downturn. 


\section{Case Study: Landowner Near Rush Creek Wind Farm}

Rush Creek is estimated to provide at least $\$ 1.8$ million annually to landowners in Lincoln, Elbert, Cheyenne, and Kit Carson counties, which is $\$ 45$ million over the life of the project for the four-county region. According to one landowner, their standard land lease agreement for Rush Creek is a percentage of gross production from the wind plant, with the percentage increasing over the turbine's lifetime. Land lease payments vary across the country but are typically on the order of $\$ 3,000$ to $\$ 6,000$ per MW (Slattery 2011). In addition to the land lease payment, landowners received land easement payments to secure the rights to install wind turbines on their land during the development phase of the Rush Creek project. These payments started in 2010 and increased incrementally until the project was operational.

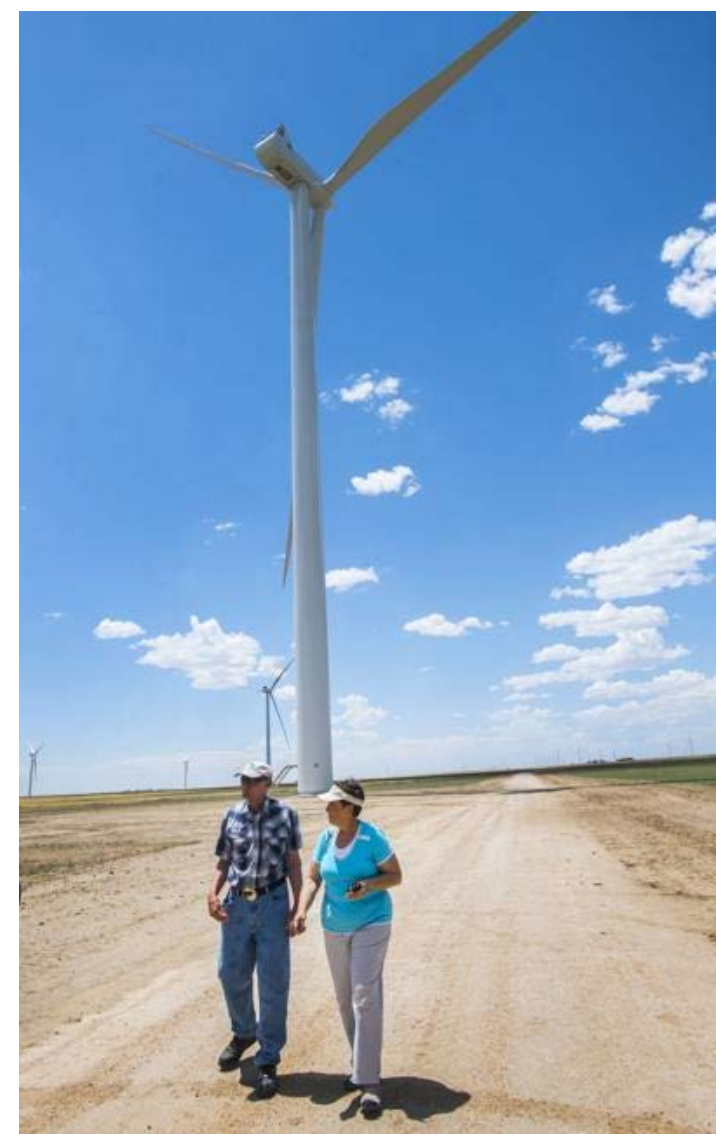

Figure 6. Virgil and Jan Kochis host Rush Creek turbines on their land.

Photo courtesy of Jan Kochis

Researchers interviewed a landowner to add a personal perspective to the land lease payment. Jan Kochis and the Kochis family own more than 10,000 acres of land on the eastern side of Elbert County. For more than 100 years, the land has been used for beef cattle operations as well as dryland farming of wheat, corn, and millet. Now, this working farm and ranch will also generate electricity from 30 wind turbines across the property. 
Jan described how land lease payments from Rush Creek support the Kochis family farm and ranch, as well as her community:

- Additional revenue supplements their income, providing stability for the farm and ranch every year, which is especially important when rain is scarce or crops do not produce.

- The developer addressed concerns regarding truck traffic, noise, visual impacts, and decommissioning through a concerted effort to engage with the community.

- Xcel Energy paid for the loss of crops during construction disruptions to farming.

- A few locals were hired to drive trucks for the construction phase. Also, Jan noticed workers purchasing materials in the local hardware store. These are examples of the Rush Creek project supporting nearby communities in addition to farmers and ranchers.

- Jan noted that the wind turbines on her property are made in Colorado. Vestas turbines are manufactured and assembled in state. 


\section{Methods}

\subsection{JEDI Model}

Researchers used the Land-Based Wind JEDI model ${ }^{16}$ to estimate employment and other economic effects from the Rush Creek Wind Farm. JEDI is an input-output (I-O) model developed by the National Renewable Energy Laboratory (NREL) and MRG \& Associates. The model estimates the number of jobs, earnings, gross domestic product (GDP), and economic output supported by the construction and operation of a wind project.

The Rush Creek Wind Farm modeled costs are based on a typical wind project in the interior region of the United States (see Table 1). NREL's 2016 Cost of Wind Energy Review provided data for the balance-of-plant (BOP) costs (Stehly et al. 2017). BOP costs accounted for $\$ 364 / \mathrm{kW}$ of the $\$ 1,164 / \mathrm{kW}$ installed project cost. A turbine cost of $\$ 800 / \mathrm{kW}$ was assumed, based on the average prices of turbines installed in the interior of the United States as well as declining turbine prices (Wiser and Bolinger 2018). Financing costs are not included in the installed project cost because the JEDI model incorporates these costs as other parameters. NREL's Wind-Plant Integrated System Design \& Engineering Model (WISDEM $®$ ) cost model was used to determine several JEDI cost categories based on this installed project cost. ${ }^{17}$

Table 1. Project Costs Overview for the Rush Creek Wind Farm

\begin{tabular}{|c|c|c|c|}
\hline Input & Cost & Source & Note \\
\hline Balance of Plant & $\$ 364 / \mathrm{kW}$ & $\begin{array}{l}2016 \text { Cost of Wind } \\
\text { Energy Review }\end{array}$ & $\begin{array}{l}\text { Typical for a } 600-\mathrm{MW} \text { wind farm } \\
\text { in the interior region of the } \\
\text { United States }\end{array}$ \\
\hline Turbine Equipment & $\$ 800 / \mathrm{kW}$ & $\begin{array}{l}2017 \text { Wind Technologies } \\
\text { Market Report }\end{array}$ & $\begin{array}{l}\text { Turbine costs ranged between } \\
\$ 750-\$ 950 / \mathrm{kW}\end{array}$ \\
\hline Installed Project & $\$ 1,164 / \mathrm{kW}$ & & $\begin{array}{l}\text { Installed project costs do not } \\
\text { include financing costs }\end{array}$ \\
\hline Annual O\&M & $\$ 43.60 / \mathrm{kW}$ & $\begin{array}{l}2016 \text { Cost of Wind } \\
\text { Energy Review }\end{array}$ & $\begin{array}{l}\text { Excludes land lease cost to } \\
\text { account for JEDI breakdown }\end{array}$ \\
\hline
\end{tabular}

Researchers also ran the JEDI model using the projected Rush Creek costs that Xcel Energy reported to the Colorado Public Utility Commission (PUC). State-level results from this cost scenario can be found in Appendix C, and four-county-level results are in Appendix D. At the time of writing, Xcel Energy estimated the Rush Creek Wind Farm would have an installed construction cost of $\$ 1,525 / \mathrm{kW}$ (not including the cost of the 645-kilovolt transmission line) and an annual O\&M cost of $\$ 46.30 / \mathrm{kW}$.

\footnotetext{
${ }^{16}$ https://www.nrel.gov/analysis/jedi/

${ }_{17}$ Documentation about WISDEM and a download of the models are available at https://nwtc.nrel.gov/content/wisdem-software-documentation.
} 
Xcel Energy's reported costs are higher than average for a typical 600-MW wind farm built during the same time period in the same region. Contingencies and other financial costs are most likely built into Xcel Energy's estimate, which is standard procedure according to a utility company stakeholder. Attempts to gain actual project costs from Xcel were unsuccessful. ${ }^{18}$ Researchers decided to use the more typical, industry average cost assumption to avoid overestimating the jobs and economic output supported by the project. Thus, primary results from this report are based on BOP costs detailed in Table 1.

The JEDI model reports economic impact estimates for two phases: construction and O\&M. Construction phase results are one-time totals that span the construction period. ${ }^{19}$ In this model scenario, the construction was estimated to be 18 months. O\&M results are annual and assumed to be ongoing for the life of the facility.

Jobs and economic impacts results are calculated across three categories, as shown in Figure 7:

- Project Development and On-site Labor Impacts refer to economic activity that is involved in a project's development and implementation that occurs on-site. These impacts generally occur in the construction, maintenance, engineering, and professional service sectors.

- Local Revenue, Turbine, and Supply Chain Impacts represent economic activity that is supported by inputs purchased for the project or business-to-business services. These include locally manufactured items, such as wind turbines, and locally procured materials used to manufacture turbines, such as steel, resin, and fiberglass. This category also includes professional services, such as attorneys who negotiate contract agreements and companies who supply construction or operation equipment.

- Induced Impacts accrue as money circulates in an economy. On-site and supply chain workers spend their earnings on goods and services. The portion of these earnings spent within the region of analysis supports induced impacts. Sectors that are affected by induced impacts include retail, lodging, restaurants, and other service and hospitality businesses.

\footnotetext{
${ }^{18}$ NREL staff and management contacted many representatives at Xcel Energy and PSCo to assist with the cost input and local share information for the Rush Creek project. Xcel referred NREL staff back to public documents and did not discuss project costs, local share, or other information. Mortenson Construction followed Xcel's lead and did not provide cost or other data. Neither company commented on the data or text that NREL provided for their review. NREL employees were allowed on-site at the Rush Creek Wind Farm in January 2018, but subsequent requests for an on-site visit were not approved.

${ }^{19}$ If, for example, JEDI reports a construction-phase impact of 300 workers to build a project that takes 2 years to complete, this is the equivalent of an average of 150 workers per year $(300 / 2=150)$. If the same project required 3 years to complete, the average would be 100 workers per year.
} 


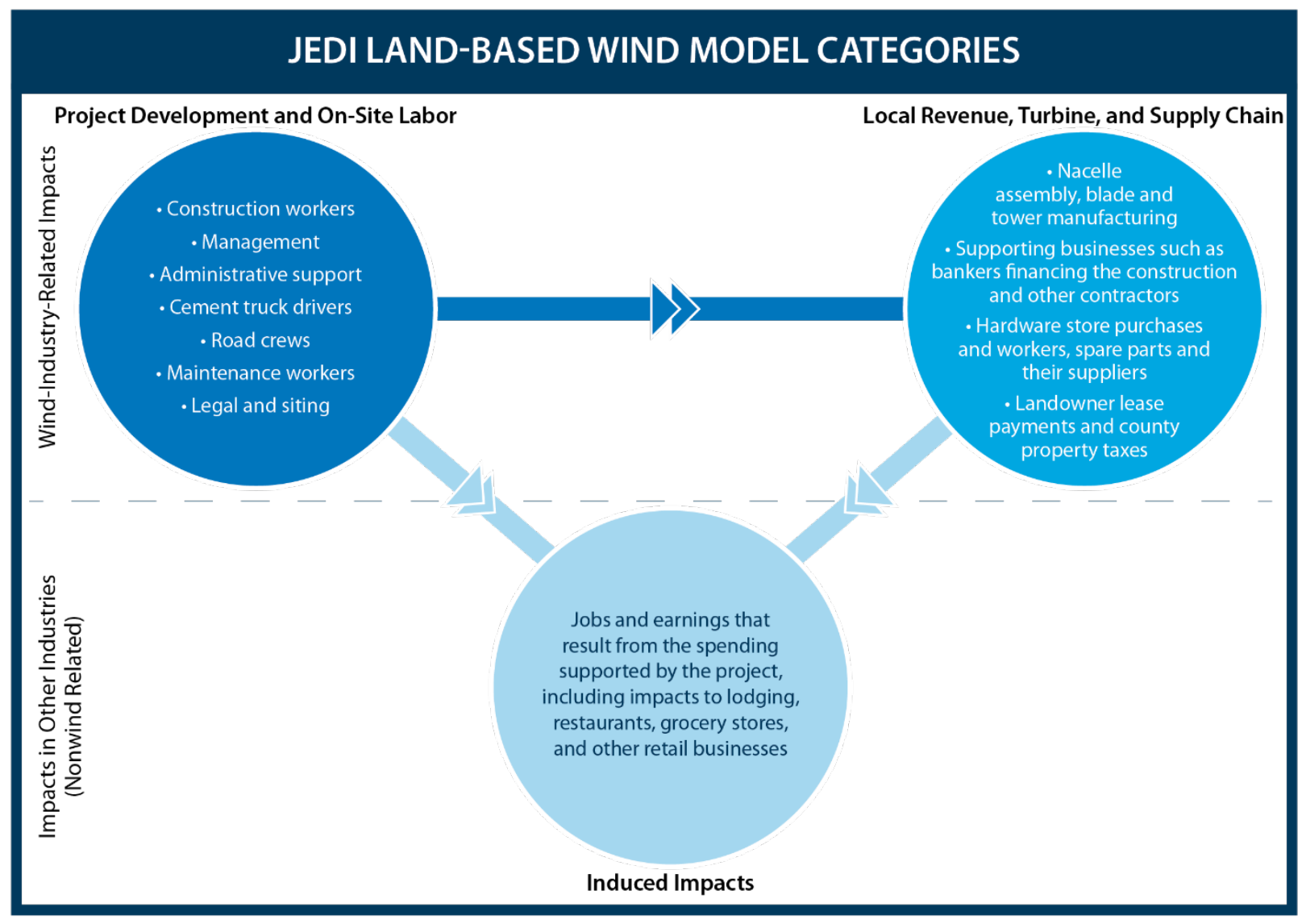

Figure 7. Examples of the three categories in the JEDI model

The JEDI model results show four metrics for each type of impact: jobs, earnings, value added (referred to as GDP), and gross economic output. JEDI metrics labels have specific definitions that inform how they should be interpreted.

- Jobs are expressed as full-time equivalent (FTE). This means one job is the equivalent of one person working 40 hours per week, year-round. Two people working full time for 6 months equals one FTE. Two people working 20 hours a week for 12 months also equals one FTE. JEDI-reported jobs are not limited to individuals who work for an employer; they could include other types of workers, such as sole proprietors (self-employed).

- Earnings include any kind of income from work. These generally include employee wages and salaries and supplemental costs paid by employers, such as health insurance and retirement. This metric can also include nonwage compensation, such as proprietor earnings.

- Gross domestic product (GDP), also referred to as value added, includes employee compensation, taxes on production and imports less government subsidies, and property-type income such as profits or returns on capital (BEA 2006). GDP reflects an industry's overall contribution to the economy. At a company level, this can be thought of as the business's revenue less expenditures on goods and services that it has to make in order for it to produce its output. 
- Gross economic output represents the total amount of economic activity that occurs within the region of analysis. The gross output of an industry is the market value of the goods and services it produces. At the business level, output can be thought of as revenue. Revenue does not consider the amount that a business pays for inputs, wages, profits, and taxes. Revenue is simply the sales of what that business produces.

\subsection{Interviews}

Researchers conducted structured and semistructured interviews. Results from these interviews are summarized in Section 3.4.1 and 3.4.2.

\subsubsection{Structured Interviews}

Researchers conducted structured interviews ${ }^{20}$ with representatives from businesses in Lincoln County to verify that rural communities near Rush Creek were experiencing the induced impacts during the construction phase, which the JEDI model estimates. Interviews were focused in Lincoln County as most businesses near Rush Creek are located in this county. Researchers provided 62 businesses with a predetermined list of 15 questions related to jobs and economic impacts that business representatives may have encountered during Rush Creek's construction phase (see Appendix F for a full list of questions). Representatives from 18 businesses responded, including owners and managers of hardware stores, grocery stores, hotels and motels, RV parks, liquor stores, restaurants, and retailers.

Questions included whether businesses had experienced economic growth, hired new employees, or required employees to work longer hours in the past year, and whether they expected growth to continue during the next 12 months. Structured interviews occurred in fall 2017. The representatives from Lincoln County businesses were presented a list of seven possible reasons for growth (if experienced) and were asked to select two. Rush Creek construction was listed as one of the reasons along with:

- Tourism

- Regional growth and development

- Internal operations

- Seasonal agricultural workers.

Researchers asked interviewees if the Rush Creek development has been beneficial to their business. Several questions related to perceptions of wind energy, including whether interviewees support wind development in their community. Results are described in Section 3.4.1.

\footnotetext{
${ }^{20}$ In structured interviews, researchers asked each individual the same set of questions. See Appendix F for a full list of interview questions.
} 


\subsubsection{Semistructured Interviews}

Researchers also met in person with 21 individuals to conduct semistructured interviews, ${ }^{21}$ focused on Rush Creek's overall economic impact to rural eastern Colorado communities. Interviewees included business owners in Lincoln and Elbert counties, turbine and equipment manufacturers, an Elbert County commissioner, a workforce center employee, an economic development corporation representative, a land-use administrator, wind farm construction and O\&M workers, a landowner with turbines on her property, industry experts, and other stakeholders. This breadth of sources provides further depth into the analysis. Interviews ranged from 30 minutes to 2 hours in length and were conducted in a conversational style.

Semistructured interviews provided information about county-level-induced impacts, perceptions of wind development in rural America, county tax revenues, land-lease payments, Rush Creekrelated employment, and local share of equipment and labor force. Interview themes are described in Section 3.4.2.

\footnotetext{
${ }^{21}$ Semistructured interviews were focused on economic impacts from the Rush Creek Wind Farm, but questions
} were not identical for each conversation. 


\section{Results}

\subsection{Statewide Jobs and Gross Economic Impacts}

JEDI model results demonstrate that the Rush Creek Wind Farm supports statewide jobs, GDP, and gross economic output (see Figure 8). ${ }^{22}$ Impacts reported are centered on JEDI model results, which include employment, property taxes, landowner revenue, and local economic activity during the construction and operation periods (see Table 2).

Although estimating all wind-related impacts was beyond the scope of this analysis, new wind power installations also provide other tangible and intangible benefits. Tangible benefits include sales and use tax revenue from purchases made in the community, water savings, ${ }^{23}$ vendor profits, and transmission line impacts. Intangible benefits include long-term electricity price stability and human health and environmental improvements (Tegen et al. 2014). Wind energy projects may also cause a loss of jobs in other sectors. For example, a concrete worker supporting building construction might leave a job to join the Rush Creek Wind Farm construction team or an investment in wind energy could create opportunities to transition jobs from other electricity generation technologies.

Figure 8 summarizes the state-level economic impacts from the Rush Creek Wind Farm. The graphic demonstrates the multiplier effect of constructing and operating a wind development (e.g., on-site impacts from construction workers support induced impacts, such as workers purchasing goods in communities).

22 JEDI results are gross, as opposed to net. For further explanation, please see model limitations in section 4.1.1.

${ }^{23}$ The same amount of electricity production from a thermal source, such as gas or coal, would use Colorado water, which is becoming a scarcer resource in much of the American West. 


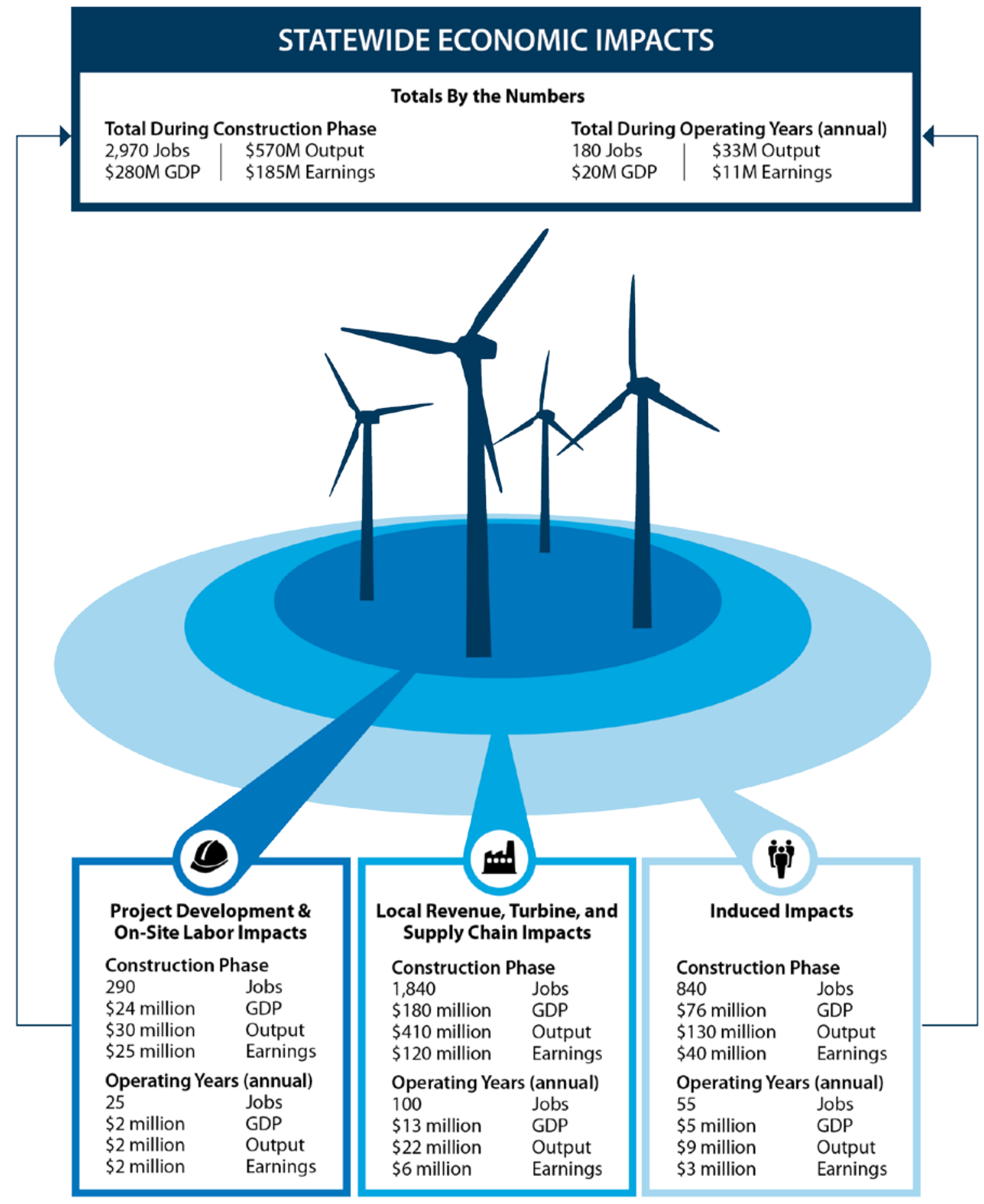

Figure 8. State-level economic multiplier effect from the 600-MW Rush Creek Wind Farm ${ }^{24}$ 
Table 2. Summary State-Level Economic Impact Estimate from the Rush Creek Wind Farm

\begin{tabular}{ll}
\hline Period & Economic Impacts \\
\hline During construction & - Supported 2,970 FTE jobs \\
& - Supported $\$ 280$ million in GDP \\
& - Supports approximately 180 jobs in Colorado annually \\
& - Supports $\$ 20$ million in GDP annually \\
During operations & Generates approximately $\$ 2.5$ million ${ }^{25}$ in annual property taxes \\
& and approximately $\$ 1.8$ million in annual income for landowners \\
& who lease their land for Rush Creek wind turbines \\
\hline
\end{tabular}

Results are provided in 2016 real dollars ${ }^{27}$

\subsubsection{Construction Phase}

Rush Creek Wind Farm construction lasted approximately 18 months, from April 2017 to October 2018. During the construction period, money spent on the project supported a wide range of economic activity, including the compensation of construction laborers, managers, engineers, and administrative staff directly working on the project. Construction costs also included purchasing wind turbine equipment and construction support materials (e.g., aggregate, hard hats, cranes). In addition, wind farm workers spend earnings in local establishments, including restaurants, grocery stores, motels, and RV parks. Estimated construction costs totaled approximately $\$ 700$ million.

Xcel Energy estimates that developers spent $75 \%$ of construction expenditures, or approximately \$524 million, within Colorado (PSCo 2017a). Most of the economic impacts incurred during the construction phase were related to the JEDI model's second multiplier effect category: Turbine and Supply Chain Impacts. This project is unique as economic impacts from in-state turbine manufacturing at Vestas plants are realized. Although the exact cost of the turbine sales agreement is confidential, Xcel Energy reported spending more than $\$ 500$ million on Vestas turbines (PSCo 2017a). In-state manufacturing greatly increased state-level content percentages of equipment (e.g., blades, nacelles, towers). However, local share for nacelles, blades, and towers did not reach 100\%, as described in Section 4.2.1, due to economic "leakage" (dollars spent outside the state), as many of the wind turbine materials and expensive internal components (e.g., gearboxes, generators) were manufactured outside of Colorado and potentially even outside of the United States.

Xcel labor assumptions were incorporated into our model estimates for statewide economic impacts. According to Xcel Energy, 67\% of Rush Creek construction workers were Colorado

\footnotetext{
${ }^{24}$ Numbers may not add due to rounding. Earnings and output values are millions of dollars in 2016 dollars. Construction and operating jobs are full-time equivalent for a period of 1 year ( $1 \mathrm{FTE}=2,080$ hours). Wind farm workers include field technicians, administration, and management. Economic impacts "During Operating Years" represent impacts that occur from wind farm operations/expenditures. The analysis does not include impacts associated with spending of wind farm "profits" and assumes no tax abatement unless noted.

${ }^{25}$ From BVEM report (PSCo 2017a). Data based on Colorado assessed property taxes for wind, which are subject to change each year with annual state valuations.

${ }^{26}$ Based on interviews with a landowner.

${ }^{27}$ Rush Creek Wind Farm construction started in 2016.
} 
residents at the time of the Best Value Employment (BVEM) filing (PSCo 2017a). When expanded to include Vestas employees and Rush Creek subcontractors, the percentage increased to $82 \%$ (PSCo 2017a). Invenergy estimates that approximately $20 \%$ of the workers involved in Rush Creek's development process were Colorado residents (PSCo 2017a). Mortenson Construction reportedly paid more than $\$ 15$ million in wages to Colorado laborers, carpenters, ironworkers, millwrights, electricians, and operators, and spent more than $\$ 32$ million with Colorado businesses during Rush Creek construction (PSCo 2017a).

\subsubsection{GDP Supported in Colorado during the Rush Creek Construction Phase}

Based on this analysis using the JEDI tool, the Rush Creek project construction expenditures supported approximately \$275 million to Colorado’s GDP (see Figure 9).

GDP includes compensation of employees, some taxes, and gross operating surplus. ${ }^{28}$ Total Project Development and On-Site Labor Impacts supported \$24 million in GDP, and \$180 million in GDP supported the Local Revenue, Turbine, and Supply Chain Impacts category. These expenditures include the turbine sales agreement with Vestas, other equipment purchases, construction materials, business-to-business services, and additional goods and services. Expenditures from construction and supply chain workers in the state supported an estimated $\$ 76$ million in GDP in the Induced Impacts category.

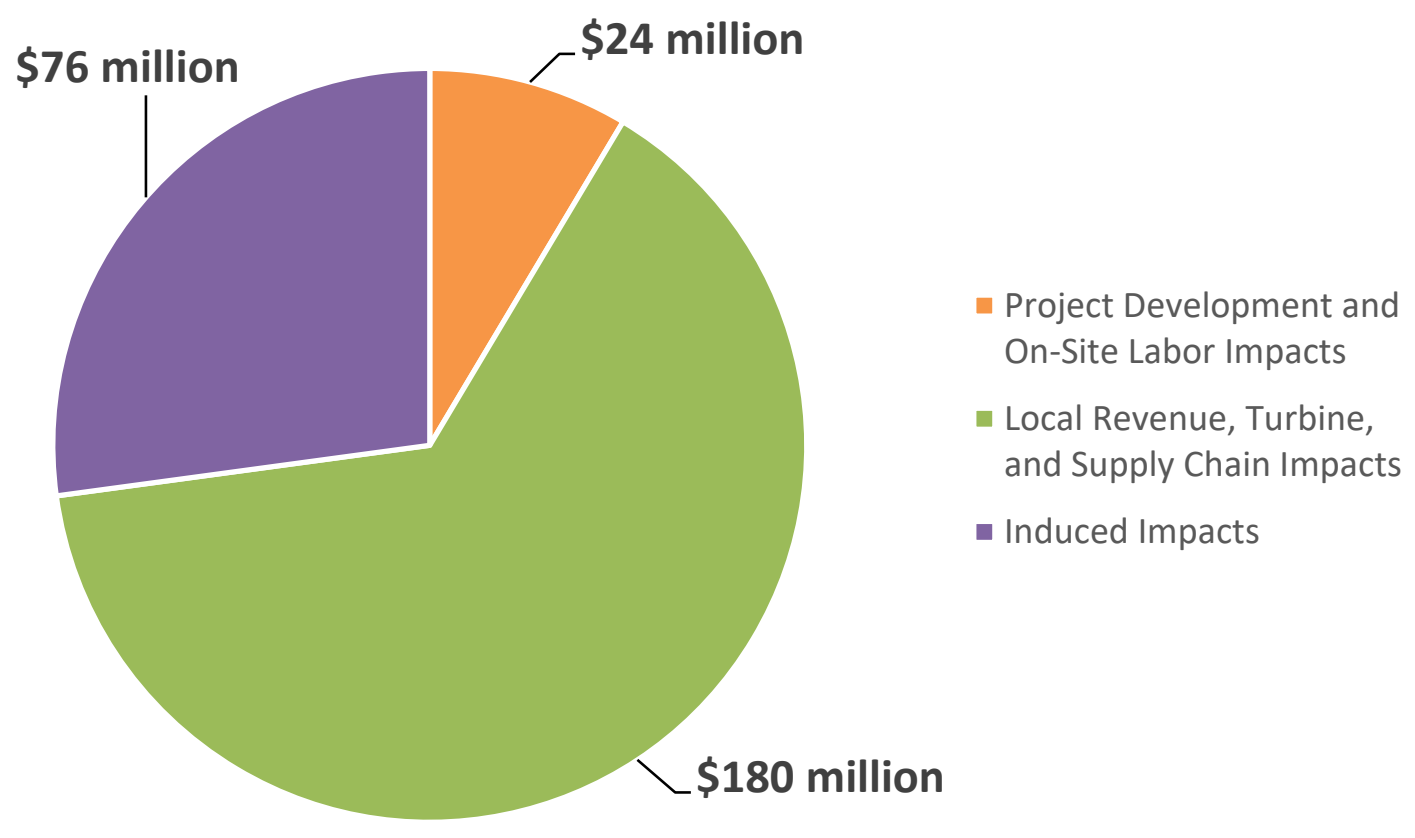

Figure 9. At the state level, the 600-MW Rush Creek Wind Farm construction phase supported \$275 million in GDP

\footnotetext{
${ }^{28} \mathrm{GDP}$ is an industry's gross output (consisting of sales or receipts and other operating income, commodity taxes, and inventory change) minus the cost of intermediate inputs (including energy, raw materials, semifinished goods, and services that are purchased from all sources).
} 


\subsubsection{Gross Economic Output in Colorado During the Rush Creek Construction Phase}

The Rush Creek Wind Farm expenditures supported approximately $\$ 570$ million of gross economic output in Colorado (see Figure 10). Most of the gross economic output, $\$ 410$ million, is supported by the JEDI category called Local Revenue, Turbine, and Supply Chain Impacts. These expenditures include the turbine sales agreement with Vestas, other equipment purchases, construction materials, business-to-business services, and additional goods and services. The JEDI category called Project Development and On-Site Labor Impacts supported \$30 million in gross economic output. Expenditures from wind and supply chain workers in the state supported $\$ 130$ million in gross output in the Induced Impacts category.

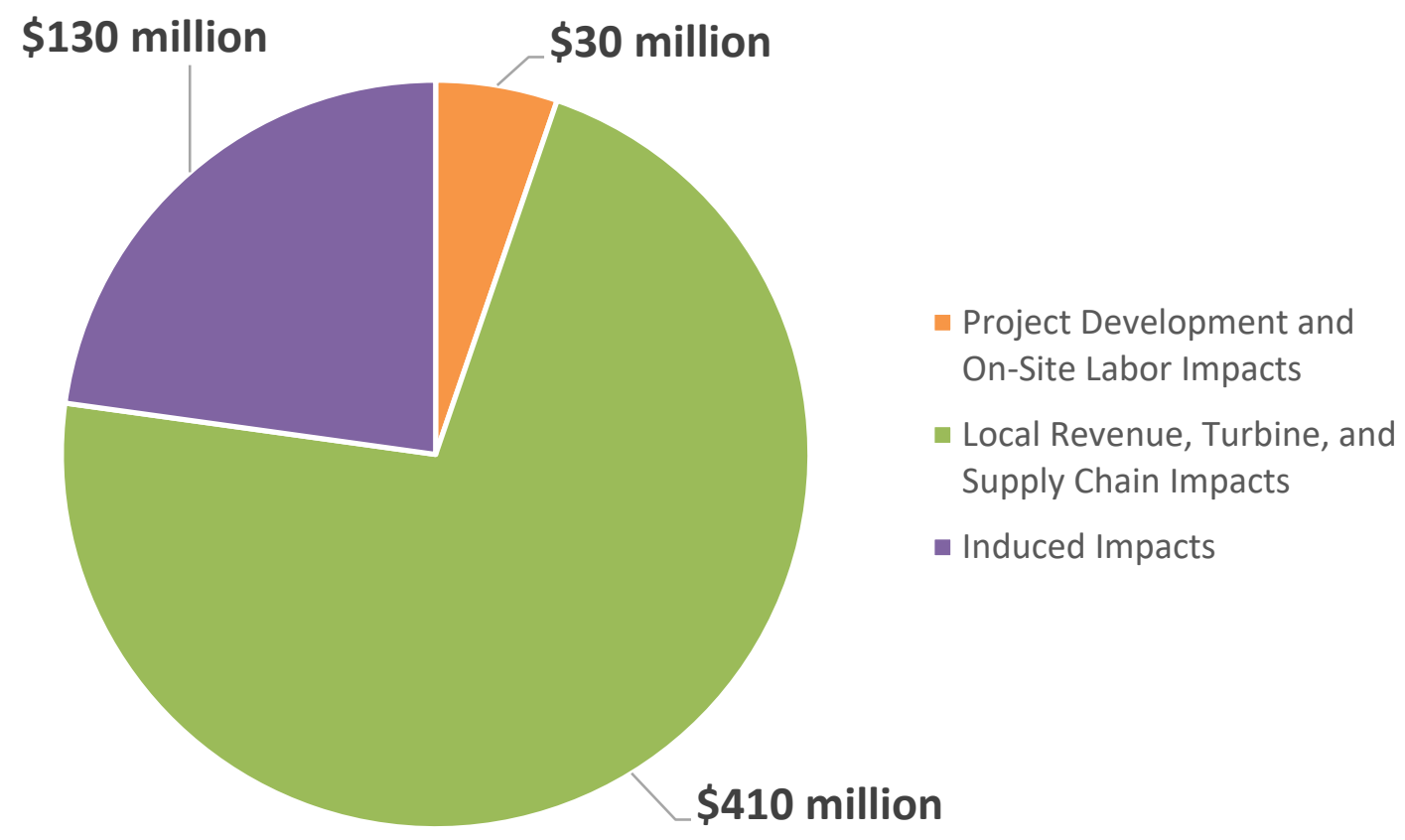

Figure 10. At the state level, the 600-MW Rush Creek Wind Farm construction phase supported $\$ 570$ million in gross economic output

\subsubsection{Jobs and Earnings in Colorado During the Rush Creek Construction Phase}

The Rush Creek Wind Farm construction supports an estimated 2,970 FTE jobs, as shown in Figure 11. Of these, 290 were on-site workers directly involved in the project's construction and development; the 290 FTEs include 245 FTEs for on-site construction and interconnection labor and 45 construction-related services, such as engineers, design, and other professional services; 1,840 FTEs were local revenue, turbine, and supply chain workers, which include Vestas employees, subcomponent manufacturing workers, construction subcontractors, and professional contractors, such as accountants and lawyers. With the expenditures they make in Colorado, onsite and supply chain workers support an additional 840 FTE-induced jobs (e.g., stay in motels and RV parks and eat at restaurants near the project, increasing the need for workers in those industries). 


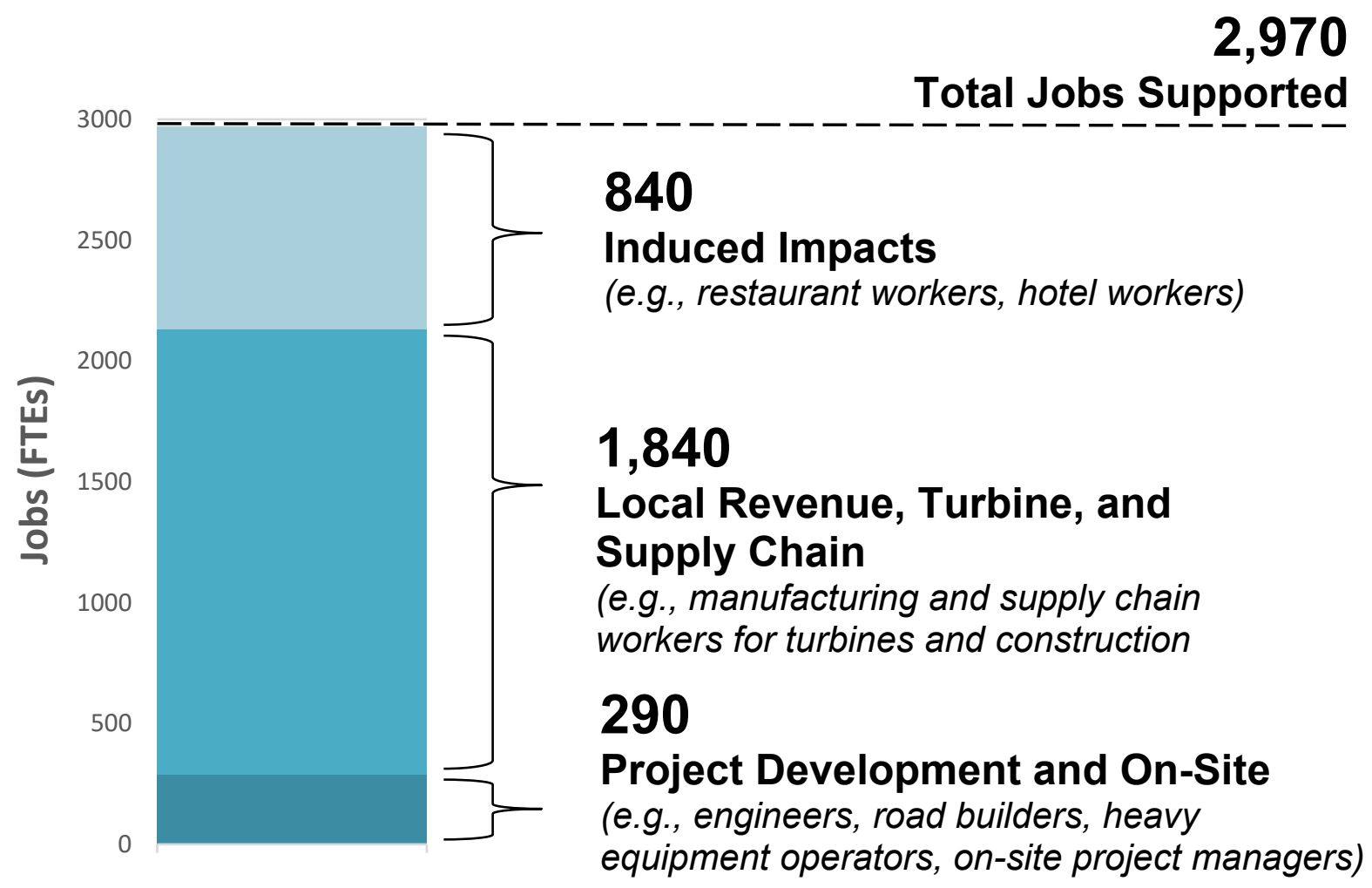

Figure 11. Statewide estimated job impacts supported from the wind plant construction phase

Our analysis estimates employees during development and on-site positions during construction (e.g., construction workers, administrative workers, engineers, managers, developer staff) earned an average of approximately $\$ 80,000$ annually. Colorado jobs that supply services of materials, turbines, and supply-chain-related materials (e.g., Vestas employees, subcomponent manufacturers, construction subcontractors, professional subcontractors) earned an average of approximately $\$ 64,000$ annually. Employees in induced jobs, supported by spending by on-site and supply chain workers (e.g., local business owners, restaurant, hotel, and RV park employees), earned an average of $\$ 51,000$ annually. ${ }^{29}$ By comparison, according to the IMPLAN model, the estimated average comparable earnings for a worker in Colorado is $\$ 55,330$ annually (Bureau of Labor Statistics [BLS] 2017). Table 3 lists the total jobs and earnings based on job category during construction.

\footnotetext{
${ }^{29}$ Annual earnings, estimated by the JEDI model, include fringe benefits (i.e., supplemental costs paid by employers, such as health insurance and retirement). Earnings can also include nonwage compensation, such as proprietor earnings.
} 
Table 3. Estimated Statewide Average Earnings for Workers During Wind Plant Construction

\begin{tabular}{ll}
\hline Impact & Average Earnings per Worker (\$/year) \\
\hline $\begin{array}{l}\text { Project Development and On-Site Labor } \\
\text { - Construction and Interconnection Labor } \\
\text { (e.g., engineers, road builders, heavy equipment operators, } \\
\text { project managers, construction workers) }\end{array}$ & $\$ 80,000$ \\
- Construction-Related Services (e.g., engineers, design, and \\
$\quad$ other professional services during development)
\end{tabular}

Note: Totals may not sum due to rounding

\subsubsection{O\&M Phase}

According to Xcel Energy, the Rush Creek Wind Farm has an expected lifetime of 25 years. O\&M of Rush Creek will require the compensation of staff, including technicians, administrative assistants, and managers. The three wind farms near Limon, Colorado, built prior to Rush Creek, have a total nameplate capacity of $850 \mathrm{MW}$ and support approximately 41 FTE on-site O\&M workers. ${ }^{30}$ During operating years, Rush Creek is expected to support jobs and economic activity across Colorado through wind farm maintenance, purchasing turbine replacement parts, vehicles, and maintenance materials, as well as induced impacts from expenditures on these activities. Because Rush Creek used wind turbines manufactured in state, replacement parts are more likely to be manufactured in Colorado at Vestas plants, increasing statewide economic impacts. In addition, an important consideration for the four-county region is ensuring O\&M jobs can be filled by local workers or workers who move into the region, enabling communities near Rush Creek to capture more of the economic impacts during the operating years.

Based on our analysis of PUC reporting from Xcel, analysis of local tax data, and interviews with community members, the Rush Creek Wind Farm's annual O\&M expenses total approximately $\$ 26$ million, or $\$ 43.60 / \mathrm{kW}$. Expenditure estimates are based on U.S. average O\&M costs for a 600-MW wind farm in similar terrain (Stehly et al. 2017). Annual expenditures in Colorado for Rush Creek O\&M are expected to total approximately $\$ 13$ million.

In addition, Xcel is expected to pay a minimum of $\$ 1.8$ million in annual land lease payments to landowners with turbines on their property and pay approximately $\$ 2.5$ million in annual property taxes to the four-county region.

\footnotetext{
${ }^{30}$ Based on the interview with the Lincoln County Economic Development Corporation.
} 


\subsubsection{Gross Domestic Product Support in Colorado During the Rush Creek O\&M Phase}

The Rush Creek Wind Farm is expected to spend $\$ 17$ million annually in the state during the O\&M phase, which includes direct operating costs, land leases, and property. This spending supports approximately \$20 million annually in GDP in Colorado, as detailed in Figure 12. Onsite labor impacts account for approximately \$2 million in GDP. Approximately $\$ 13$ million in GDP is realized through supply chain, landowner revenue, or business-to-business services. Spending by on-site and supply chain workers support approximately \$5 million in GDP associated with induced impacts to nonwind industries.

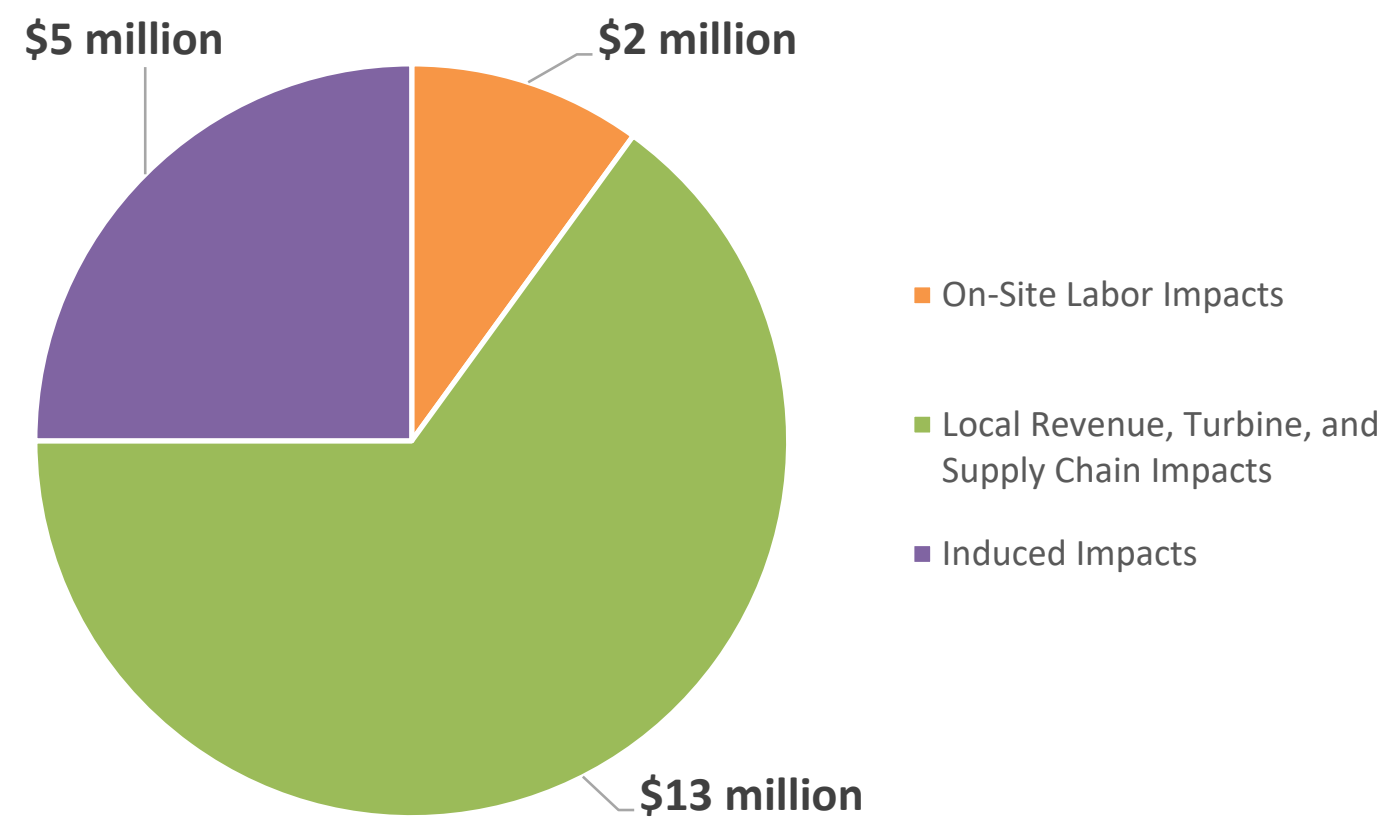

Figure 12. At the state level, Rush Creek is estimated to support $\$ 20$ million in GDP annually during operating years 


\subsubsection{Gross Output in Colorado During the Rush Creek O\&M Phase}

The Rush Creek Wind Farm supported approximately $\$ 33$ million in gross output to Colorado annually (see Figure 13). On-site labor impacts account for $\$ 2$ million in economic activity. Local revenue, turbine, and supply chain impacts support approximately $\$ 22$ million in gross output. Induced impacts support approximately $\$ 9$ million in economic activity.

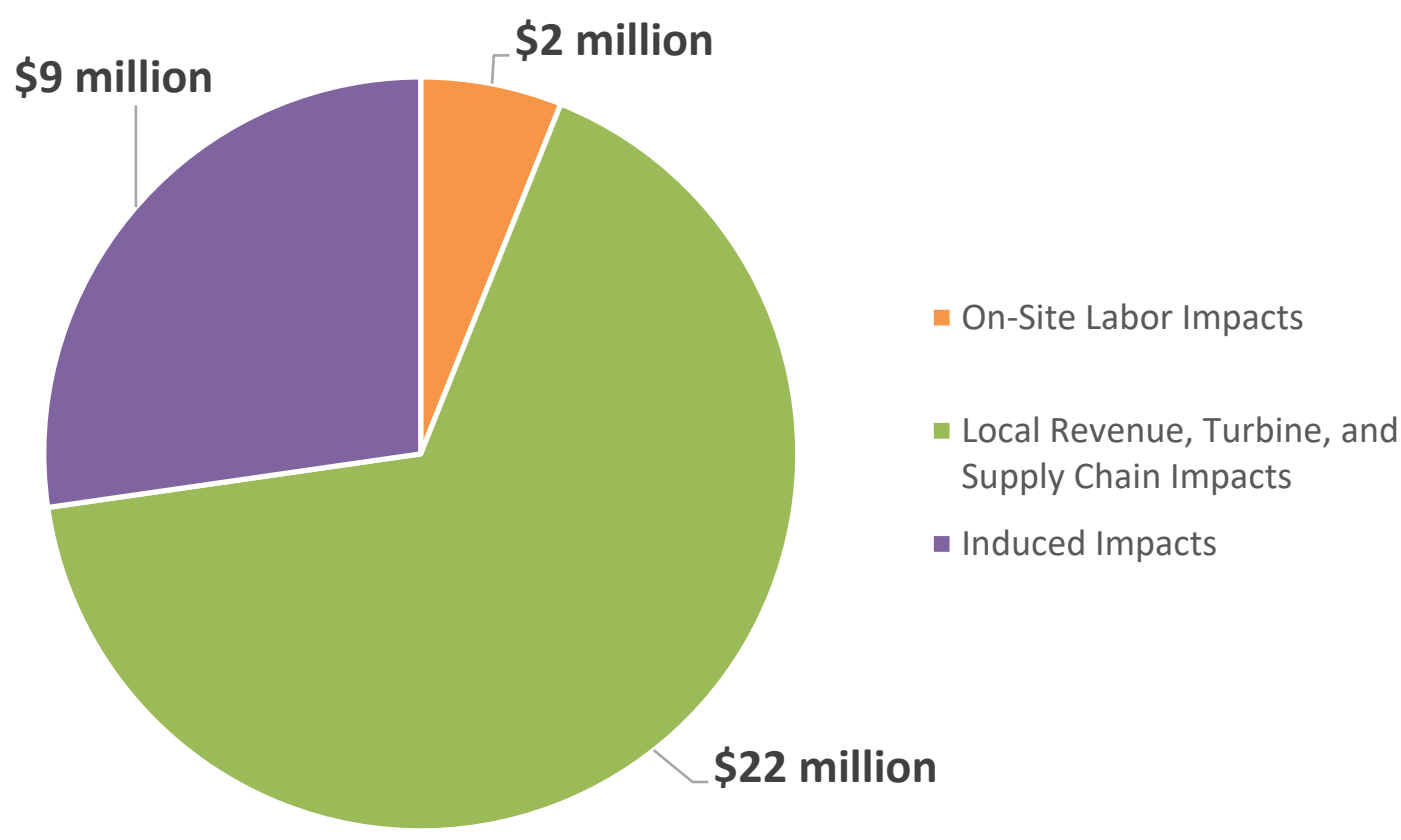

Figure 13. At the state level, Rush Creek is estimated to support $\$ 33$ million in gross economic output annually during operating years

\subsubsection{Jobs and Earnings in Colorado During the Rush Creek O\&M Phase}

Rush Creek will require long-term employees to operate and maintain the facility during the 25year life of the project. Xcel Energy has a 5-year service maintenance and warranty contract with Vestas to provide O\&M services for the wind plant. This contract can be extended. Colorado residents or people who relocate to Colorado are expected to be hired for these ongoing O\&M positions.

Based on JEDI model results, Rush Creek is estimated to support 180 long-term FTEs annually during operating years, which includes on-site O\&M workers, supporting business and supply chain jobs, and employment supported through induced impacts. Figure 14 shows the annual FTE jobs supported in each JEDI category. Of these, 25 FTE jobs are on-site positions directly involved with maintaining the wind farm. These positions include wind technicians, managers, administrative professionals, and other workers. JEDI estimates approximately 100 O\&M jobs are supported from local revenue, turbine, and supply chain. These include contractual services, manufacturing workers for replacement parts and O\&M materials, and jobs arising because of revenue or returns realized locally (e.g., landowner payments) from the plant's operation. Expenditures made by on-site and supply chain workers support an additional 55 FTE induced jobs in unrelated industries that provide local services or goods. 


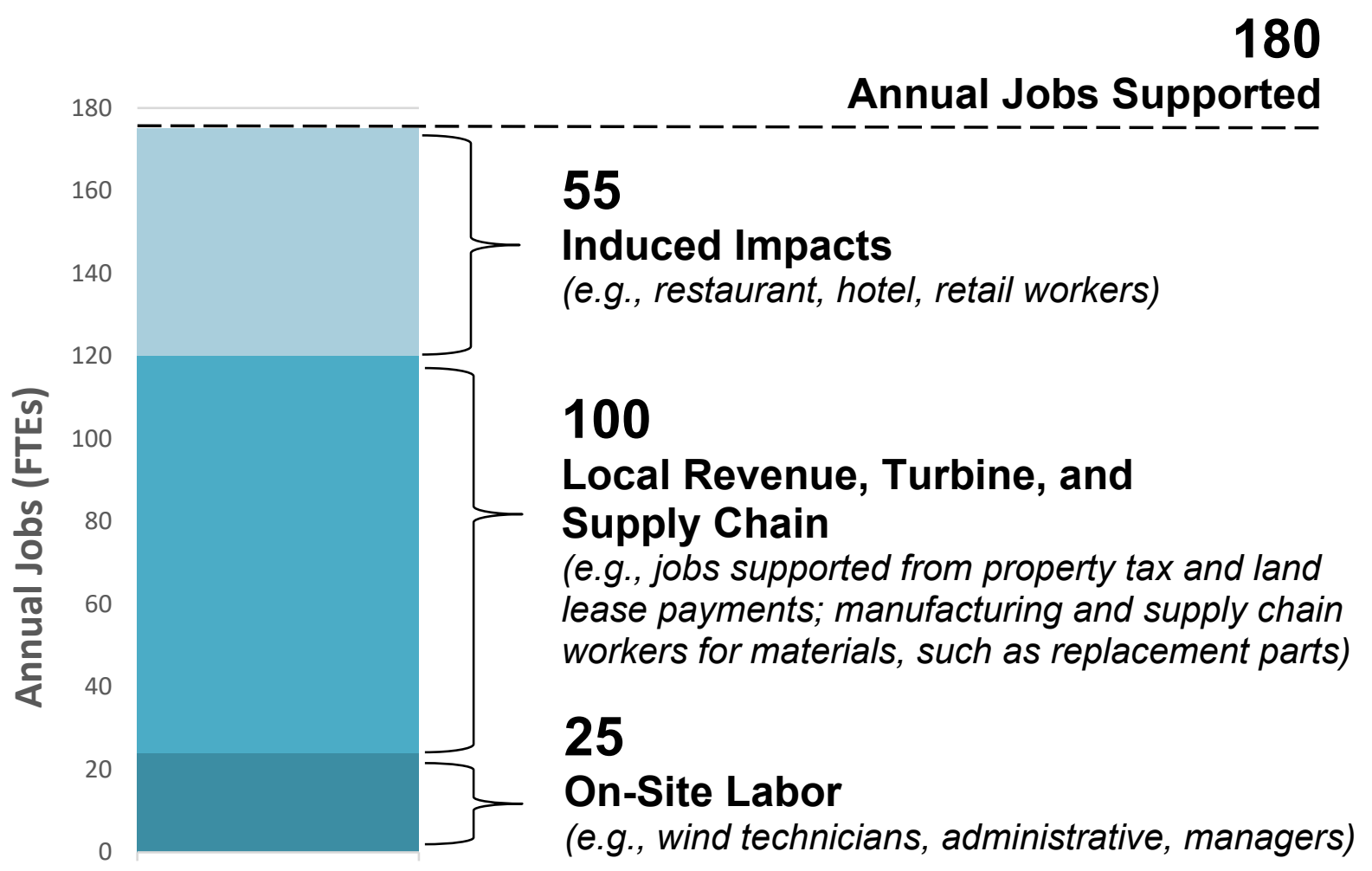

Figure 14. Statewide estimated jobs supported from Rush Creek during operating years

Earnings for workers during the O\&M phase are similar to those estimated during the construction phase, but salaries and spending patterns differ slightly. Our analysis estimates employees performing on-site labor during the operations period (e.g., wind technicians, operations managers) earn an average of approximately $\$ 80,000$ annually. Colorado jobs that supply replacement parts or off-site services earn an average of approximately $\$ 65,000$ annually. Employees working in induced jobs supported by spending by O\&M workers (e.g., hotel, restaurant, retail workers, and managers) earn an average of $\$ 54,000$ annually. ${ }^{31}$ All of these positions have higher earnings than the IMPLAN modeled average of $\$ 27,820$ within the region, and all but induced average earnings are higher than the statewide $\$ 55,330$ average (BLS 2017). Table 4 lists the total earnings based on job category during O\&M.

\footnotetext{
${ }^{31}$ Annual earnings include fringe benefits (i.e., supplemental costs paid by employers, such as health insurance and retirement). Earnings can also include nonwage compensation, such as proprietor earnings.
} 
Table 4. Estimated Statewide Annual Earnings for Workers During Rush Creek O\&M phase

\begin{tabular}{ll}
\hline Impact & Average Earnings per Worker (\$/year) \\
\hline $\begin{array}{l}\text { On-Site Labor Impacts } \\
\text { (e.g., wind technicians, administrative workers, managers) }\end{array}$ & $\$ 80,000$ \\
$\begin{array}{l}\text { Local Revenue, Turbine, and Supply-Chain-Related Labor } \\
\text { (e.g., jobs supported from property tax and land lease payments; }\end{array}$ & $\$ 65,000$ \\
$\begin{array}{l}\text { manufacturing and supply chain workers for materials, such as } \\
\text { replacement parts) }\end{array}$ & \\
$\begin{array}{l}\text { Induced Impacts (e.g., hotel, restaurant, retail workers) } \\
\text { Average Estimated Total Earnings }\end{array}$ & $\$ 54,000$ \\
\hline
\end{tabular}

Note: Totals may not sum due to rounding 


\section{Case Study: Rush Creek Partnership Melody Bolton, Limon Workforce Center}

Wind projects generally require several hundred people working construction at one time. Colorado Workforce Centers are state-funded organizations that provide free employment assistance to Colorado employers and job seekers. As the director of the Limon Workforce Center for more than two decades, Melody Bolton has assisted with staffing construction of every wind project in the area. Bolton helped Xcel Energy and Mortenson Construction find qualified local workers since the project's inception. According to Bolton, companies try to fill positions with local employees to fulfill legal obligations. Still, large construction projects, such as Rush Creek, need larger workforces than a small county like Lincoln can provide.

Bolton recognized that she would need to collaborate closely with nearby counties to fill the construction workforce needs for the Rush Creek Wind Farm. Melody created and spearheaded the Rush Creek Partnership to help local job seekers gain valuable employment. The partnership consists of 10 counties that are part of the Eastern Region Workforce Centers (Cheyenne, Elbert, Kit Carson, Lincoln, Logan, Morgan, Phillips, Sedgwick, Yuma, and Washington Counties), two counties that are part of the Southeast Region Workforce Centers (Crowley and Kiowa Counties), and one county that is part of the Pikes Peak Workforce Center (El Paso County). As the first step of the partnership, Bolton created a list for Mortenson Construction and Xcel Energy of construction subcontractors in their respective partnership areas. Several of the subcontractors listed were hired to work on Rush Creek, including Halde, a water hauler, and Stone Oil, a fuel supplier.

Before Rush Creek, Lincoln County had an unemployment rate of 2.5\%. Current unemployment in Lincoln County is $1.9 \%$, and Bolton attributes a significant portion of this drop to Rush Creek. "In a small county of 5,000 people, a $0.6 \%$ drop in unemployment makes a large difference," she says. Bolton is inspiring the future generation of wind power workers by bringing local youth groups on tours of Cedar Point Wind Farm, where they can go inside a wind turbine. Bolton wants to share with the next workforce generation that wind energy can provide future career opportunities. 


\subsection{In-State Wind Turbine Manufacturing}

Vestas is a vertically integrated ${ }^{32} \mathrm{OEM}$ that manufactures and assembles nacelles and manufactures blades and towers in Colorado and across the globe. A wind-related supply chain has also developed in Colorado to provide subcomponents, parts, and materials to Vestas. In 2007, Vestas decided to base their operations in Colorado because of the state's geographic location near customers; proximity to rail for transportation; and a quality, skilled workforce (Office of Energy Efficiency and Renewable Energy 2009).Colorado's state policy support for clean energy and assistance from the Colorado Office of Economic Development and International Trade, also worked extensively to bring companies like Vestas and their suppliers to the state. ${ }^{33}$

The wind industry is an economic driver in Colorado, especially in the communities surrounding Vestas manufacturing plants. Vestas is currently one of the largest employers in Brighton, Windsor, and Pueblo.

This is the first JEDI study that captures and models the actual economic impacts from both the manufacturing and installation of wind turbines in the same state. ${ }^{34}$ Researchers visited the Vestas nacelle, blade, and tower manufacturing facilities to better understand the economics and workforce in wind turbine production. The existing supply chain in Colorado was also analyzed, including visiting Aluwind, an aluminum component supplier for Vestas. Figure 15 provides a map showing the current OEM and wind-related supply chain for major wind turbine components in Colorado.

\footnotetext{
${ }^{32}$ Vestas has the capability to design, engineer, manufacture, and maintain major components for several wind turbine models.

${ }^{33}$ Personal conversation with Chancellor Don Elliman at University of Colorado Anschutz Campus. Chancellor Elliman led the Office of Economic Development and International Trade under the Ritter Administration in Colorado.

${ }^{34}$ NREL staff and others have previously modeled in-state manufacturing but only from theoretical inputs.
} 


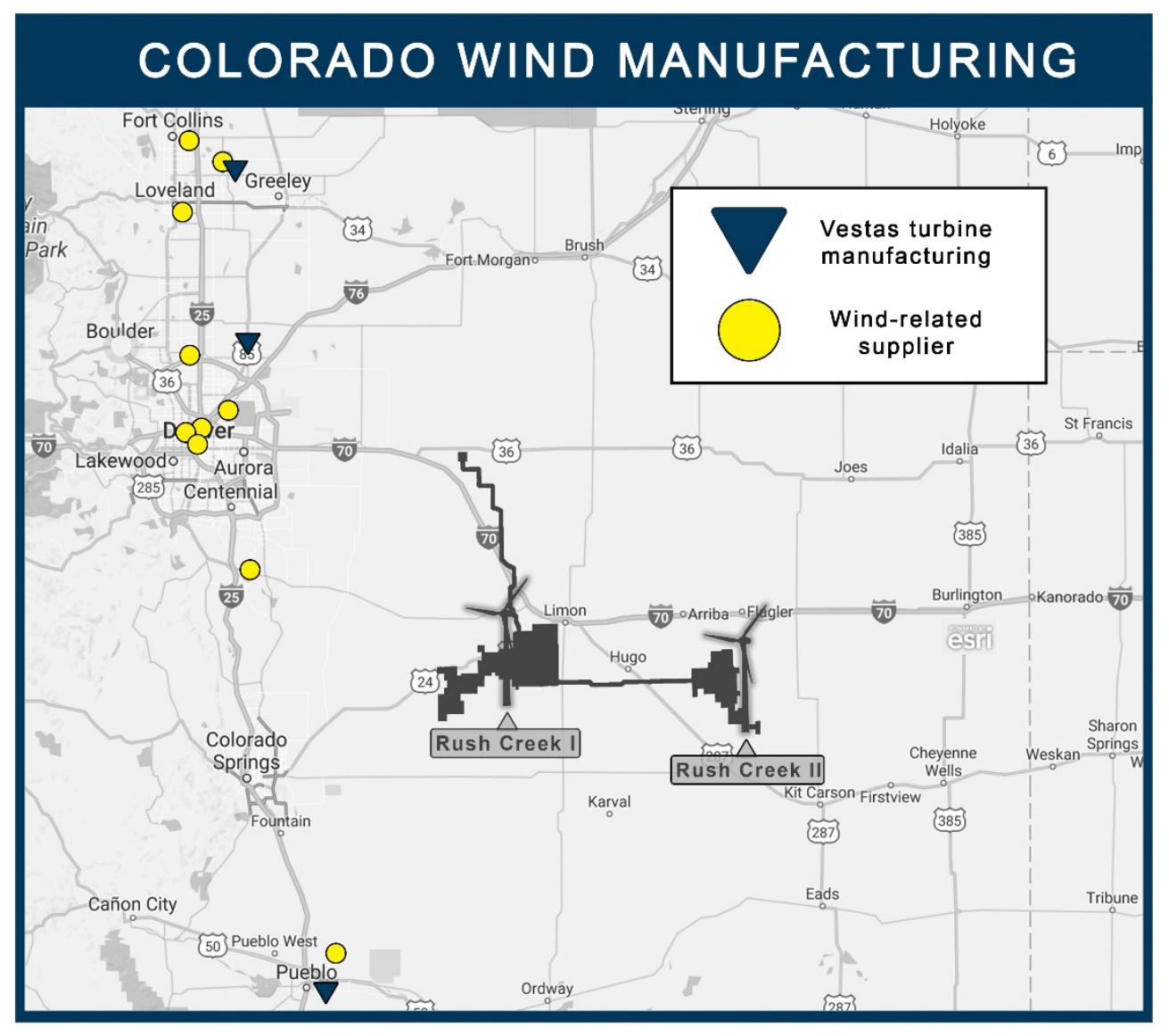

Figure 15. Map of Colorado's Rush Creek Wind Farm (locations I and II) and wind turbine manufacturing and supply chain facilities

Local manufacturing is the largest driver of jobs and economic development during construction because the turbine costs typically account for $65 \%$ to $85 \%$ of the total cost of a new wind farm (Lantz and Tegen 2008). The estimated turbine costs for Rush Creek, including transportation, accounted for $69 \%$ of the total installed project cost. In-state sourcing of major turbine components, which is often not possible, greatly increases the economic impact of a given wind farm project. Expenditures spent in state include labor, assembly, and parts and materials sourced from the Colorado wind-related supply chain.

Estimates of in-state manufacturing expenditures are shown in Table 5. To determine a reasonable Colorado local share for the turbine costs, researchers utilized the cost breakdowns outlined in the U.S. Wind Energy Manufacturing and Supply Chain: A Competitiveness Analysis (Global Wind Network [GLWN] 2014). Using empirical manufacturing and supply chain information obtained during interviews, analysts applied assignments to percentages of the cost being spent in Colorado, as shown in Appendix E. 
Table 5. Percentage of Costs Spent In-State To Manufacture Wind Turbines in Colorado

\begin{tabular}{lll}
\hline Equipment & In-State Local Share & Information Source \\
\hline Nacelle assembly & $16 \%$ & $\begin{array}{l}\text { Vestas manufacturing facilities and other } \\
\text { sources. See Appendix E for a more } \\
\text { detailed breakdown. }\end{array}$ \\
\hline Blades & $66 \%$ & \\
\hline Towers & $37 \%$ & \\
\hline
\end{tabular}

Turbine costs, not including transportation, are estimated at $\$ 800 / \mathrm{kW}$ of the $\$ 1,164 / \mathrm{kW}$ installed Rush Creek project cost. Figure 16 shows the total turbine and supply chain jobs and GDP supported during the construction of the Rush Creek Wind Farm estimated from turbine expenditures in Colorado based on previously detailed assumptions. Manufacturing of the turbines began in mid-2017, with production lasting several months.

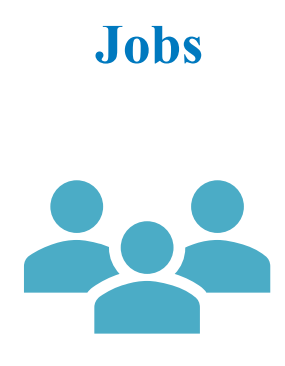

830 FTES

\section{GDP Supported}

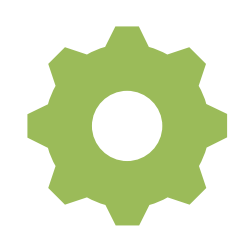

$\$ 90$ million

Figure 16. Colorado statewide wind turbine manufacturing and supply chain economic impacts supported during the construction of Rush Creek

Turbine and supply chain impacts account for the largest construction-related economic impacts in Colorado. Researchers also modeled the economic impacts using cost data reported by Xcel Energy to the Colorado PUC. At an installed project cost of $\$ 1,525 / \mathrm{kW}$, as reported by Xcel Energy, turbine costs are assumed to be $\$ 1,000 / \mathrm{kW}$. These results are reported in Appendices C and D. Modeling a higher capital cost for turbines increases the number of jobs and GDP supported during construction in modeled results.

\subsubsection{Colorado's Manufacturing and Supply Chain}

Colorado has a high domestic wind turbine manufacturing capability, being the only state in which turbine, blade, and tower facilities are co-located (AWEA 2017). Because manufacturing supports the largest economic impact from wind energy deployment, Colorado has been able to capture additional economic impacts through the in-state Vestas wind manufacturing and supply chain (Lantz and Tegen 2008). Jobs and economic activity are maximized not only from in-state wind deployment, but Colorado also benefits from out-of-state wind energy projects that source Vestas wind turbines.

\subsubsection{Original Equipment Manufacturer: Vestas}

Vestas operates four Colorado-based facilities, including a nacelle assembly facility in Brighton, blade manufacturing facilities in Brighton and Windsor, and a tower facility in Pueblo.

Researchers toured the Vestas nacelle, blade, and tower facilities to collect data on employment and turbine production as well as to gain a better understanding of wind manufacturing's role in 
Colorado's economy. Vestas employs approximately 3,500 manufacturers and administrative staff in Colorado. ${ }^{35}$ The number of employees includes full- and part-time labor, not FTEs (which are reported in this document). JEDI results would consider a part-time employee as 0.5 FTE. Table 6 shows estimated employment and actual plant production at Colorado-based Vestas plants.

Table 6. Vestas Manufacturing Plant Data for Colorado-Based Facilities

\begin{tabular}{lllll}
\hline Vestas Equipment & Location & $\begin{array}{l}\text { Year } \\
\text { Operational }\end{array}$ & $\begin{array}{l}\text { Employees } \\
\text { (Approximate) }\end{array}$ & $\begin{array}{l}\text { Vestas Equipment } \\
\text { (Annual Production) }\end{array}$ \\
\hline Turbine (nacelle assembly) & Brighton & 2010 & 400 & 1,500 \\
Blades & Windsor & 2008 & 850 (estimated) & 1,200 single blades \\
Blades & Brighton & 2011 & 875 & 1,500 single blades \\
Towers & Pueblo & 2010 & 800 & 1,000 all sections \\
\hline
\end{tabular}

Source: Vestas site visits

\subsubsection{Supply Chain for Wind Turbine Manufacturing in Colorado}

A wind-related supply chain has developed in Colorado after Vestas opened wind manufacturing plants. Table 7 lists the Colorado-based manufacturing plants and purchases made from the state's supply chain. There are other wind-related manufacturing companies not listed here that support the U.S. wind industry but not necessarily Vestas.

Using an in-state supply chain increases the local share of expenditures from wind turbine manufacturing, supporting indirect jobs and economic activity reported in the JEDI model. Researchers analyzed Colorado's wind supply chain to better understand the supply chain's role in supporting a domestic, utility-scale OEM, such as Vestas. Vestas works with several suppliers in Colorado, which provide structural internals, blade materials, and electrical wiring.

${ }^{35}$ Data from Vestas site visits 
Table 7. Vestas Wind-Related Manufacturing and Supply Chain Locations in Colorado

\begin{tabular}{lll}
\hline Company & Component/Subcomponent & City \\
\hline Aluwind & Aluminum structural internals & Castle Rock \\
\hline Creative Foam Composite Systems, LLC & Cores for blades & Berthoud \\
Hexcel & Blade materials (composites) & Windsor \\
Vestas & Blades & Windsor \\
Vestas & Blades & Brighton \\
Vestas & Towers & Pueblo \\
Vestas & Turbine (nacelle assembly) & Brighton \\
Walker Components Group & Electrical wire and cable & Denver \\
\hline
\end{tabular}

In blade manufacturing, the primary Colorado-based material supplier is Hexcel, which operates near Vestas in Windsor, Colorado. Hexcel manufactures prepregs, which is a fiber-reinforced material that has been preimpregnated with a resin system. ${ }^{36}$ Carbon fiber, fiberglass, and resins are a major material cost driver for blades (GLWN 2014). An estimated $66 \%$ of costs associated with blade manufacturing are spent in Colorado. A significant portion of this expenditure is from carbon and fiberglass blade materials produced by Hexcel.

Even smaller expenditures in the supply chain can have economic impacts on the communities near the supplier operations, as is the case with Aluwind. Aluwind manufactures structural aluminum for tower and nacelle internals at a plant in Castle Rock, Colorado. In our local expenditure calculations, doorframes and other tower internals were estimated at less than $1 \%$ of the tower cost. However, even this smaller supply chain in-state expenditure has an impact on supporting jobs and economic activity. Aluwind employs 40 to 45 workers. Manufacturing aluminum structural internals for 300 wind turbines, the number of turbines at Rush Creek, would require 2 to 3 months of work. ${ }^{37}$ Moreover, Aluwind's operations support a multiplier effect in the supply chain. Aluwind employs a trailer truck company from Colorado Springs, Colorado, to transport aluminum structural internals to Vestas facilities. Aluwind also uses a company in Pueblo, Colorado, to help cut aluminum brackets. ${ }^{38}$ Because Vestas uses several Colorado-based suppliers, the construction of the Rush Creek Wind Farm supported the state's wind supply chain.

Although there is an established wind turbine manufacturing and supply chain in Colorado, there is still a theoretical opportunity to develop the local supply chain to minimize economic "leakage." For example, $100 \%$ of the Rush Creek nacelles were assembled in Colorado; however, a large majority of the internal components - which make up most of the cost-were manufactured outside the state, such as the generators and gearboxes. As such, the nacelle equipment cost is assumed to only have $16 \%$ in-state content. Similarly, $100 \%$ of the Rush Creek towers were manufactured in Colorado, but the steel was imported from outside of the state.

\footnotetext{
${ }^{36}$ Data from Hexcel email correspondence

${ }^{37}$ Data from Vestas site visit

${ }^{38}$ Data from Aluwind site visit
} 
Because the steel is the main component in the towers, only slightly more than one-third of the estimated tower cost is spent in Colorado (see Appendix E for details). The in-state expenditures include Vestas manufacturing and supply chain labor, administrative, material, parts, and subcomponent costs. These local expenditures could be increased for future projects by attracting new wind suppliers to the state. ${ }^{39}$ Because the nacelle assembly requires numerous subcomponents and is the costliest equipment expenditure, the supply chain for nacelle assembly is the most sensitive expenditure.

\subsubsection{State-Level Manufacturing Jobs Supported from Rush Creek Turbines}

Assuming the turbines cost $\$ 800 / \mathrm{kW}$ (installed project cost $\$ 1,164 / \mathrm{kW}$ ), of the 2,970 total jobs supported during construction, 1,840 jobs are from the turbine and supply chain impacts. Of the 1,840 jobs supported, 830 jobs are related to impacts from the manufacturing and supply chain of turbines in Colorado for the Rush Creek project. ${ }^{40}$ See Figure 17 for a breakdown by turbines (nacelle assembly), blades, and towers. The remaining jobs supported are related to impacts from construction and development spending on other construction equipment and materials.

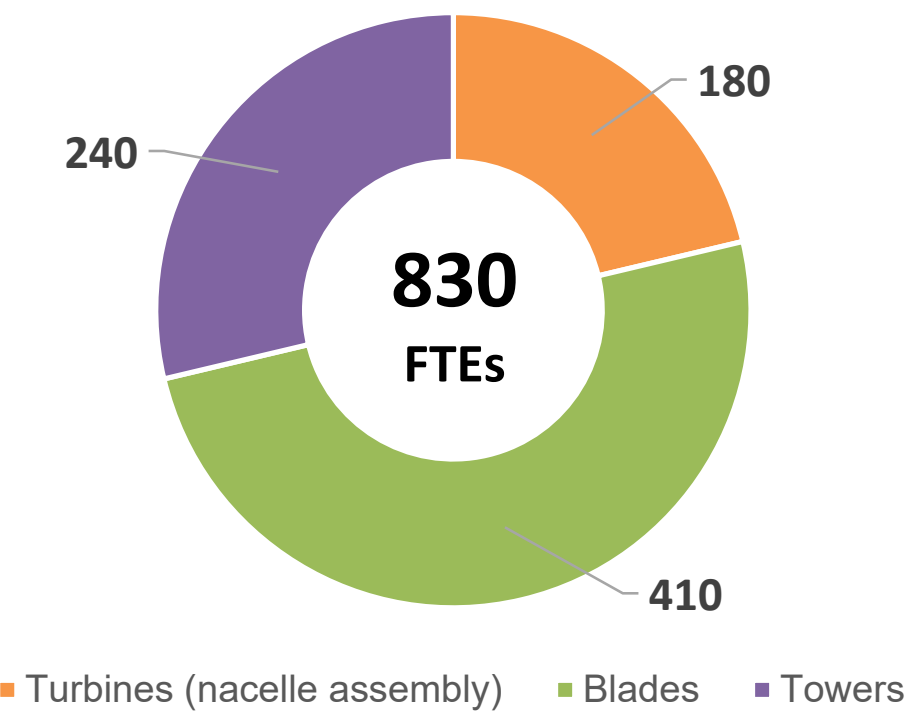

Figure 17. Number of jobs supported from wind turbine manufacturing and supply chain based in Colorado from Vestas wind turbines installed at Rush Creek, assuming $\$ \mathbf{8 0 0} / \mathbf{k W}$ wind turbine cost

Although turbines (nacelle assembly) are the largest cost per kilowatt for all inputs into a turbine system, the supply chain is limited for nacelle subcomponents, parts, and materials in Colorado. Therefore, relatively fewer turbine (nacelle assembly) jobs are supported. The supply chain for blades in Colorado is more extensive. The higher number of jobs for blade manufacturing includes jobs such as those supported at Hexcel. Further expanding the supply chain would

\footnotetext{
${ }^{39}$ Additional analysis would be needed to understand how developing a more local supply chain impacts the cost of wind turbines and manufacturing of equipment.

${ }^{40}$ To determine economic impacts from the manufacturing and supply chain of turbines in Colorado, researchers only modeled turbine costs and local share, excluding other construction costs. The 1,840 jobs from turbine and supply chain impacts also include indirect impacts from construction and development spending on materials.
} 
increase expenditures spent locally on turbines during wind farm construction, supporting more jobs in Colorado, but needs to be weighed against the overall economic efficiency of having a more comprehensive in-state supply chain.

\subsubsection{State-Level Manufacturing GDP Supported from Rush Creek Turbines}

Assuming the equipment costs $\$ 800 / \mathrm{kW}$ (installed project cost $\$ 1,164 / \mathrm{kW}$ ), of the $\$ 280$ million in GDP supported during construction, $\$ 180$ million is attributed to total turbine and supply chain impacts. Of the $\$ 180$ million GDP supported, $\$ 90$ million is related to the manufacturing and supply chain of turbines in Colorado for the Rush Creek project. ${ }^{41}$ See Figure 18 for a breakdown by turbines (nacelle assembly), blades, and towers. The remaining GDP supported is related to impacts from construction and development spending on other construction equipment and materials.

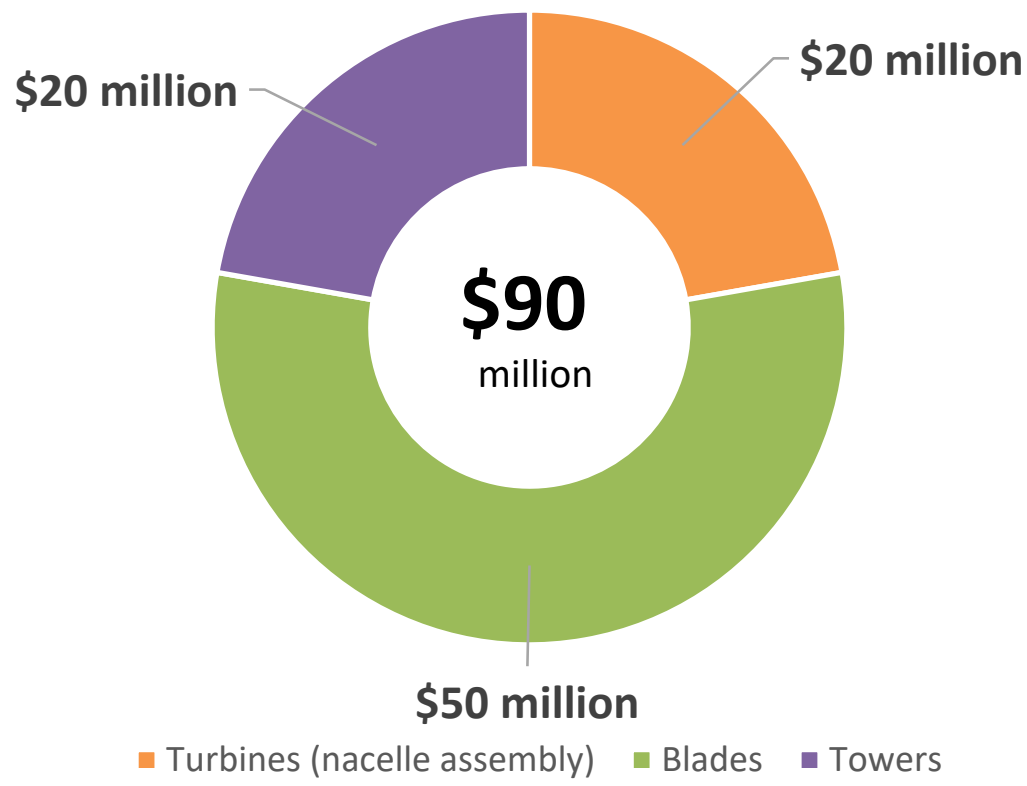

Figure 18. GDP supported from wind turbine manufacturing and supply chain based in Colorado from Vestas wind turbines installed at Rush Creek, assuming $\$ 800 / \mathbf{k W}$ wind turbine cost

Vestas uses the most local materials and parts in manufacturing wind turbine blades in Colorado, followed by towers and then nacelles. The percentage of local expenditures spent in state directly affects the corresponding GDP. Therefore, blades contributed the largest portion of GDP supported during the construction of Rush Creek, followed by towers and turbines (nacelle assembly). Expanding the supply chain would increase expenditures spent locally during wind farm construction, supporting more GDP in Colorado's economy.

\footnotetext{
${ }^{41}$ To determine economic impacts from the manufacturing and supply chain of turbines in Colorado, researchers only modeled turbine costs and local share, excluding other construction costs. The 1,840 jobs from turbine and supply chain impacts also includes indirect impacts from construction and development spending on materials.
} 


\subsubsection{Four-County Region Manufacturing Economic Impacts}

The economic impacts from the manufacturing and supply chain are minimal in the counties surrounding Rush Creek. There are no wind manufacturing or supply chain plants located in the four-county region. In JEDI model runs, local share expenditures in the four-county regions were modeled at $0 \%$, indicating no costs to manufacture wind turbines were spent in Elbert, Lincoln, Kit Carson, or Cheyenne Counties. However, construction spending on materials and turbine equipment has multiplier effects, supporting indirect and induced jobs and economic impacts in counties.

Involvement with the Rush Creek project has allowed rural communities near the project to better understand the expansion potential of their economies through wind manufacturing and the supply chain. Researchers learned during interviews with stakeholders, such as the Lincoln Country Economic Development Corporation (LCEDC), that the area near Limon, Colorado, was designated Foreign Trade Zone No. 293 by the U.S. Department of Commerce in 2015. A foreign trade zone incentivized Vestas to build manufacturing plants in Windsor, Brighton, and Pueblo. Now, community leaders are exploring economic development opportunities from attracting a wind energy supplier into this area. 


\section{Case Study: Colorado's Wind Manufacturing Annual Impact}

\section{Vestas and Wind-Related Supply Chain}

Vestas operates a nacelle assembly, blade and tower manufacturing plants, which are co-located with a wind-related supply chain, providing subcomponents, parts, and materials (see Table 7). This unique co-location supports in-state jobs and GDP.

Figure 19 shows the total jobs and GDP supported from producing Vestas wind turbines, assuming fully facility utilization in Colorado for 1 year. These estimates were calculated using the JEDI model, local share assumptions from Table 5, and annual Vestas production data from Table 6. Analysts estimated local share based on interviews with Vestas personnel regarding their supply chain in Colorado. To determine the turbine expenditures spent in state, analysts used the methodology detailed in Section 4.2.1.

These estimates include FTE jobs and GDP supported in Vestas plants, supply chain facilities, and associated induced impacts. Because 300 Vestas wind turbines were installed at Rush Creek, a portion of the jobs and GDP from Vestas' manufacturing and supply chain can be attributed to Rush Creek (see Sections 3.2.2 and 3.2.3).

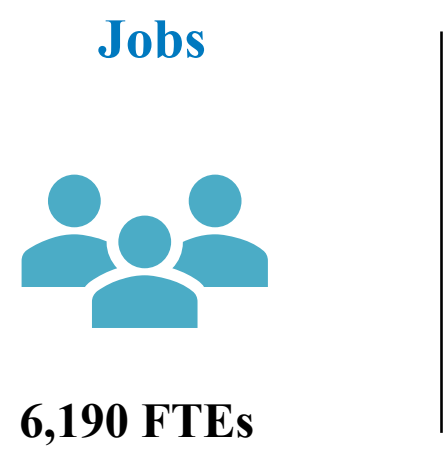

\section{GDP Supported}

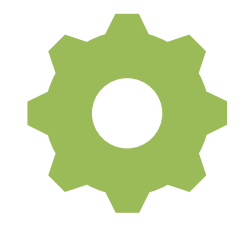

$\$ 630$ million

Figure 19. Colorado statewide wind turbine manufacturing and wind-related supply chain impacts from Vestas' estimated production in 2017 


\subsection{Four-County Region Jobs and Economic Impacts}

Researchers used the JEDI model to estimate jobs and economic impacts for the four-county region in which the Rush Creek Wind Farm is located. This region includes Cheyenne, Elbert, Kit Carson, and Lincoln Counties in the eastern Colorado plains. The region has a population of 40,191 and a workforce of 9,294 people. ${ }^{42}$ The unique 2016 IMPLAN multipliers for each county were aggregated to create the four-county regional multipliers used in the JEDI model. Regional JEDI model runs were completed using the same cost assumptions as the state level, an installed construction cost of $\$ 1,164 / \mathrm{kW}$ and an annual O\&M cost of $\$ 43.60 / \mathrm{kW}$, which are representative U.S. costs for a 600 -MW wind farm in similar terrain. Figure 20 summarizes the economic impacts for the four-county region.

${ }^{42}$ From 2017 U.S. Bureau of Labor Statistics data. Workforce references fourth quarter 2017 Bureau of Labor Statistics data. 


\section{FOUR-COUNTY REGION ECONOMIC IMPACTS}

Totals By the Numbers

Total During Construction Phase

620 Jobs $\mid$ \$78M Output

\$36M GDP \$23M Earnings

Total During Operating Years (annual)

47 Jobs

\$6M GDP $\quad$ \$2M Earnings

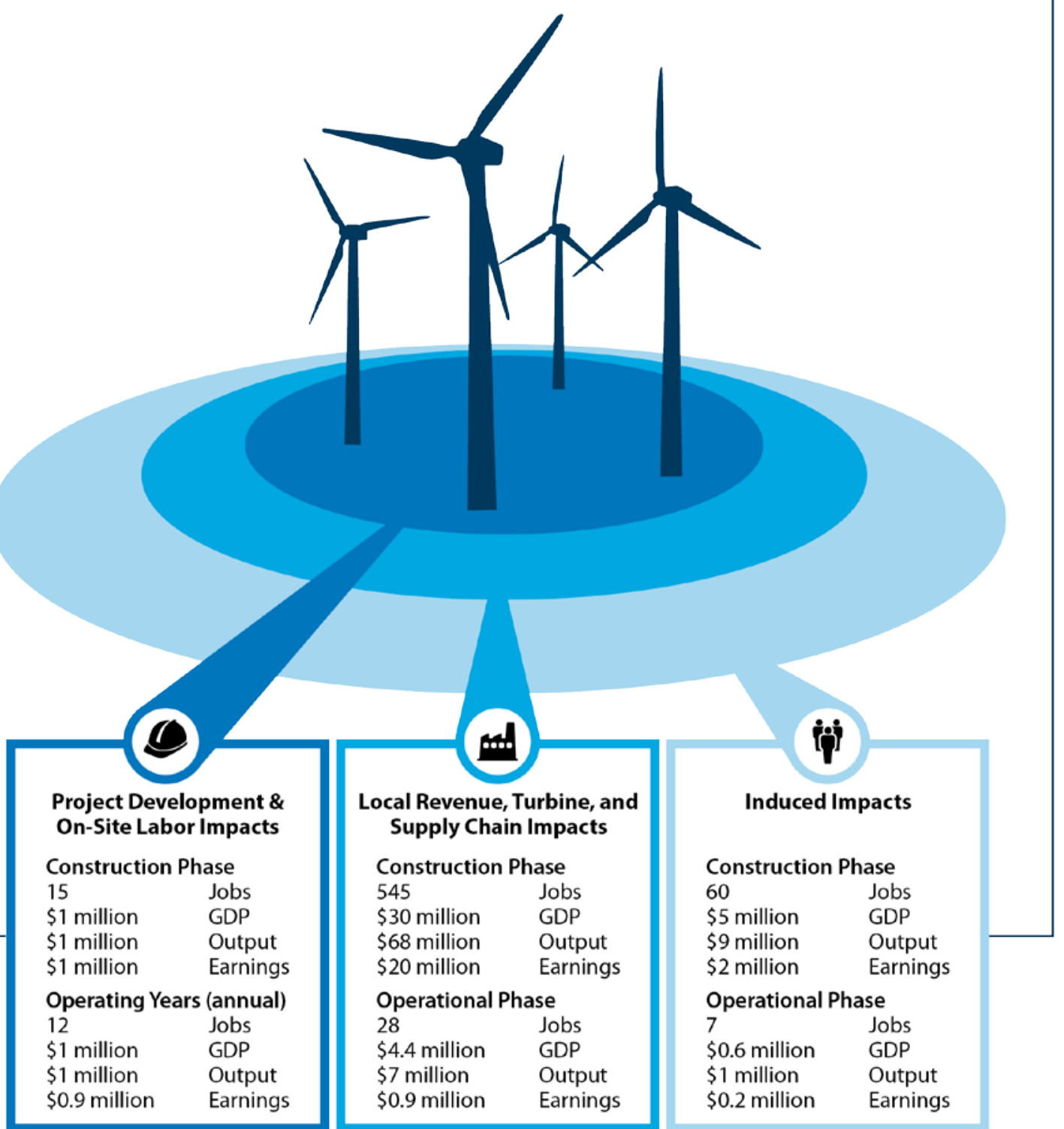

Figure 20. Four-county region economic impacts from the 600-MW Rush Creek Wind Farm ${ }^{43}$ 


\subsubsection{Construction Phase}

Approximately $\$ 68$ million of Rush Creek project expenditures were spent within the fourcounty region during the 18-month construction phase. Permits and fees to the counties are an estimated $\$ 7$ million in one-time payments prior to construction. These payments were provided to the counties in the form of sales and use taxes and building permit fees (see Case Studies: Economic Development in Rural America and Planning for the Future).

\subsubsection{GDP Supported in Four-County Region During Construction Phase}

Project expenditures in the region supported approximately $\$ 36$ million in GDP to the fourcounty region. Vestas manufacturing takes place outside of the four-county region; therefore, economic impacts resulting from turbine manufacturing are not represented in the region. Nevertheless, the Local Revenue and Supply Chain Impacts category also includes tool and equipment purchases from local hardware stores; construction materials, such as aggregate for concrete; local subcontractor wages; and local revenues, such as land easement and site permitting (see Figure 21). Approximately $\$ 30$ million in GDP is supported by the Local Revenue and Supply Chain Impacts category. Project Development and Onsite Labor Impacts supported \$1 million GDP in the four-county region. For the Induced Impacts category, on-site and supply chain workers increase local business in the region as they stay in nearby motels and RV parks, eat at restaurants, and shop at grocery stores. Expenditures from wind and supply chain workers created an induced impact, which supported an estimated \$5 million in GDP.

\footnotetext{
${ }^{43}$ Numbers may not add due to rounding. Earnings and output values are millions of dollars in 2016 dollars. Construction and operating jobs are full-time equivalent for a period of 1 year ( $1 \mathrm{FTE}=2,080$ hours). Wind farm workers include field technicians, administration, and management. Economic impacts "During Operating Years" represent impacts that occur from wind farm operations/expenditures. The analysis does not include impacts associated with spending of wind farm "profits" and assumes no tax abatement unless noted.
} 


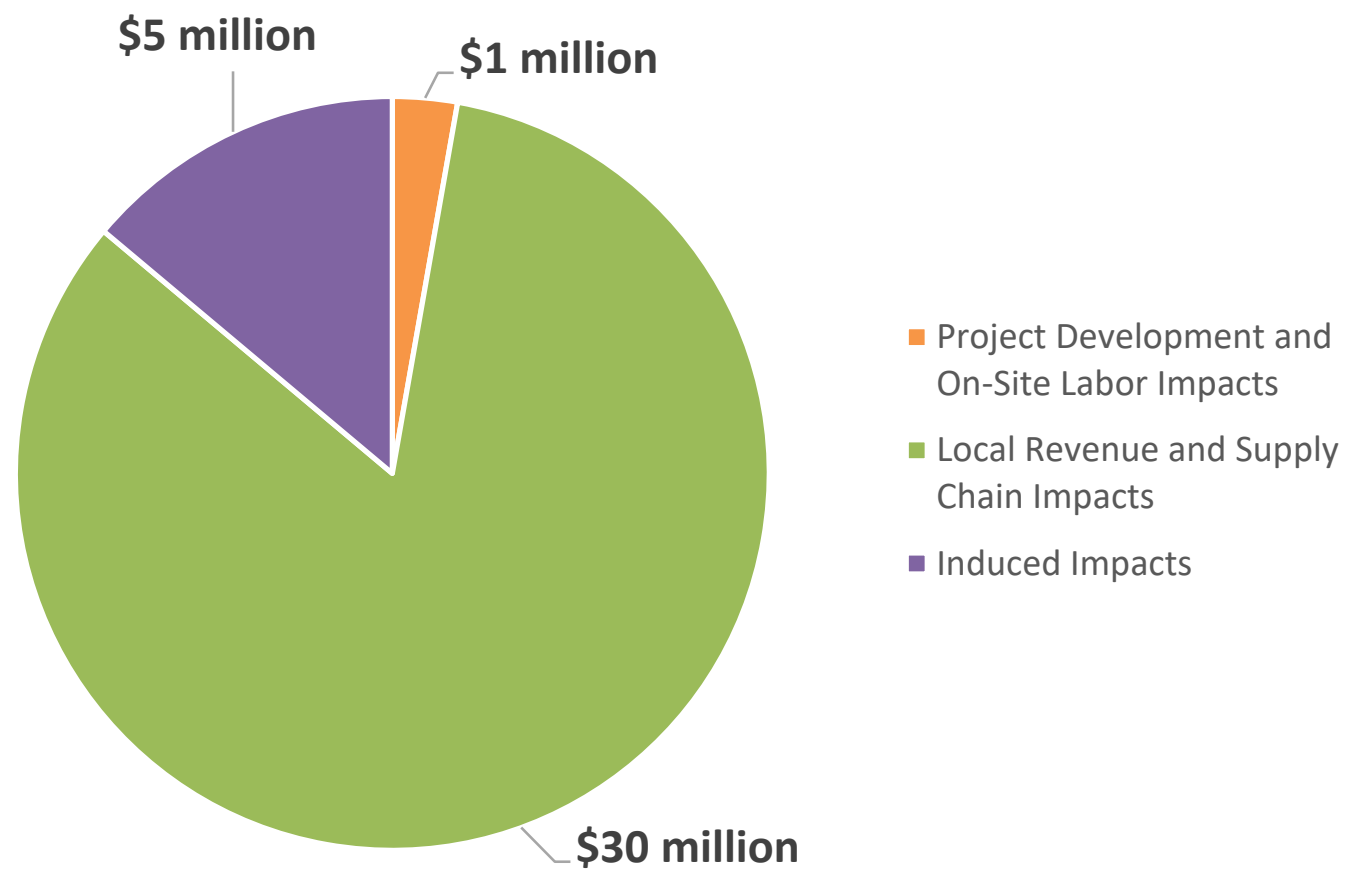

Figure 21. In the four-county region, the 600-MW Rush Creek Wind Farm construction phase supported \$36 million in GDP

\subsubsection{Gross Output in Four-County Region During Construction Phase}

Project expenditures in the region supported approximately $\$ 78$ million in gross economic output (i.e., total amount of economic activity) in the four-county region (see Figure 22).

Approximately $\$ 68$ million in gross output is supported by the Local Revenue and Supply Chain Impacts category. Project Development and On-Site Labor Impacts supported \$1 million in gross output in the four-county region. Expenditures from wind and supply chain workers supported an estimated $\$ 9$ million in induced gross output. 


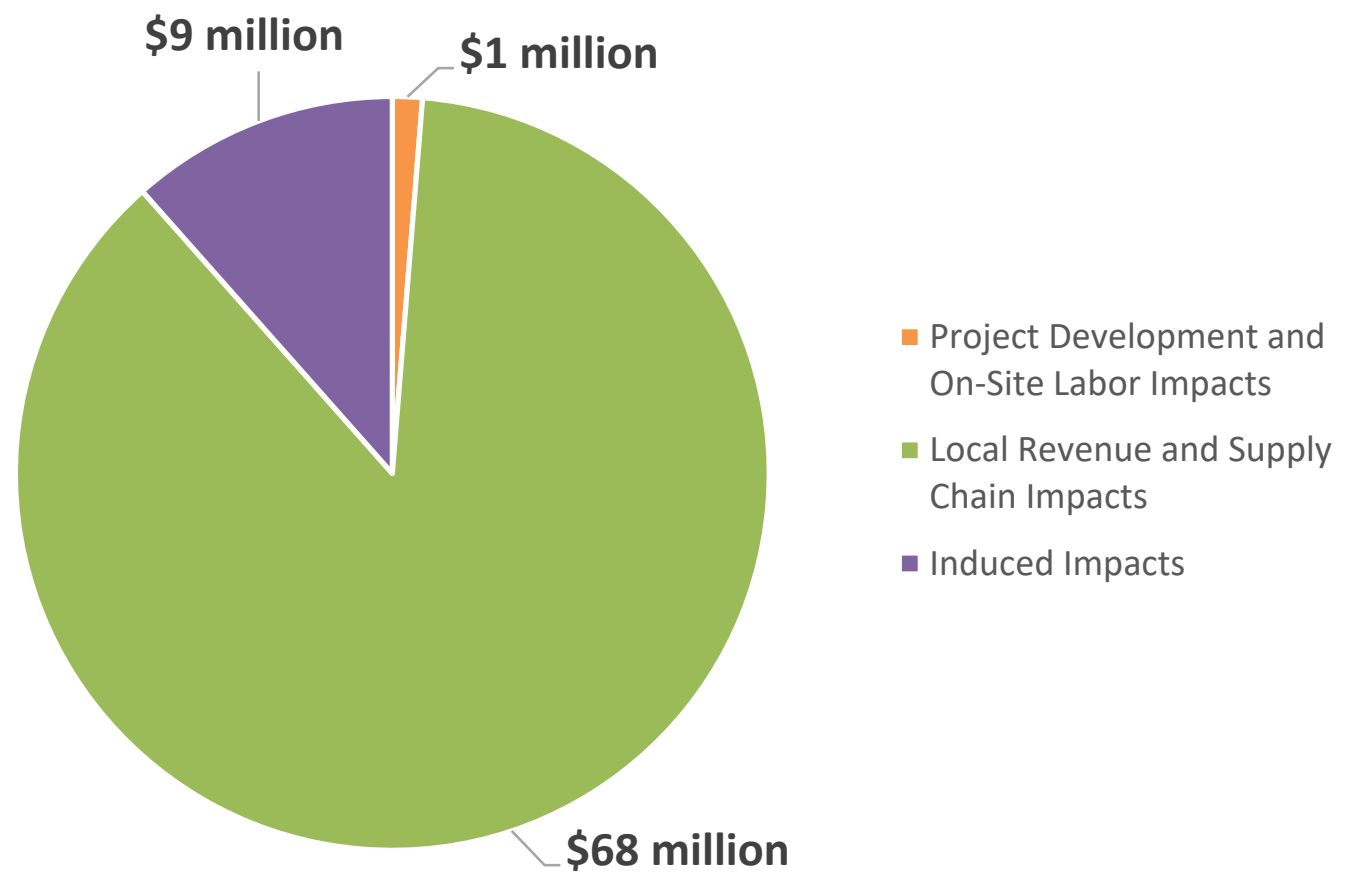

Figure 22. In the four-county region, the 600-MW Rush Creek Wind Farm construction phase supported $\$ 78$ million in gross economic output

An estimated 50\% of the Rush Creek Wind Farm's construction material expenditures were spent within the four-county region (see Figure 24). The local share of construction materials was estimated using the list of Colorado contractors from Xcel Energy's BVEM report (PSCo 2017a). Researchers used NREL's WISDEM cost model to estimate the construction material cost breakdown. In a typical wind project, concrete represents about half of the cost that is spent on construction materials. The sand, aggregate, and water used for Rush Creek's concrete were sourced locally and purchased within the four-county region. Concrete mixing occurred on-site, but an out-of-state company supplied the batch plant and other concrete-mixing equipment (see Figure 23). Other costly construction materials, such as rebar and bolt cages, were supplied by Colorado-based companies located outside the four-county region. 


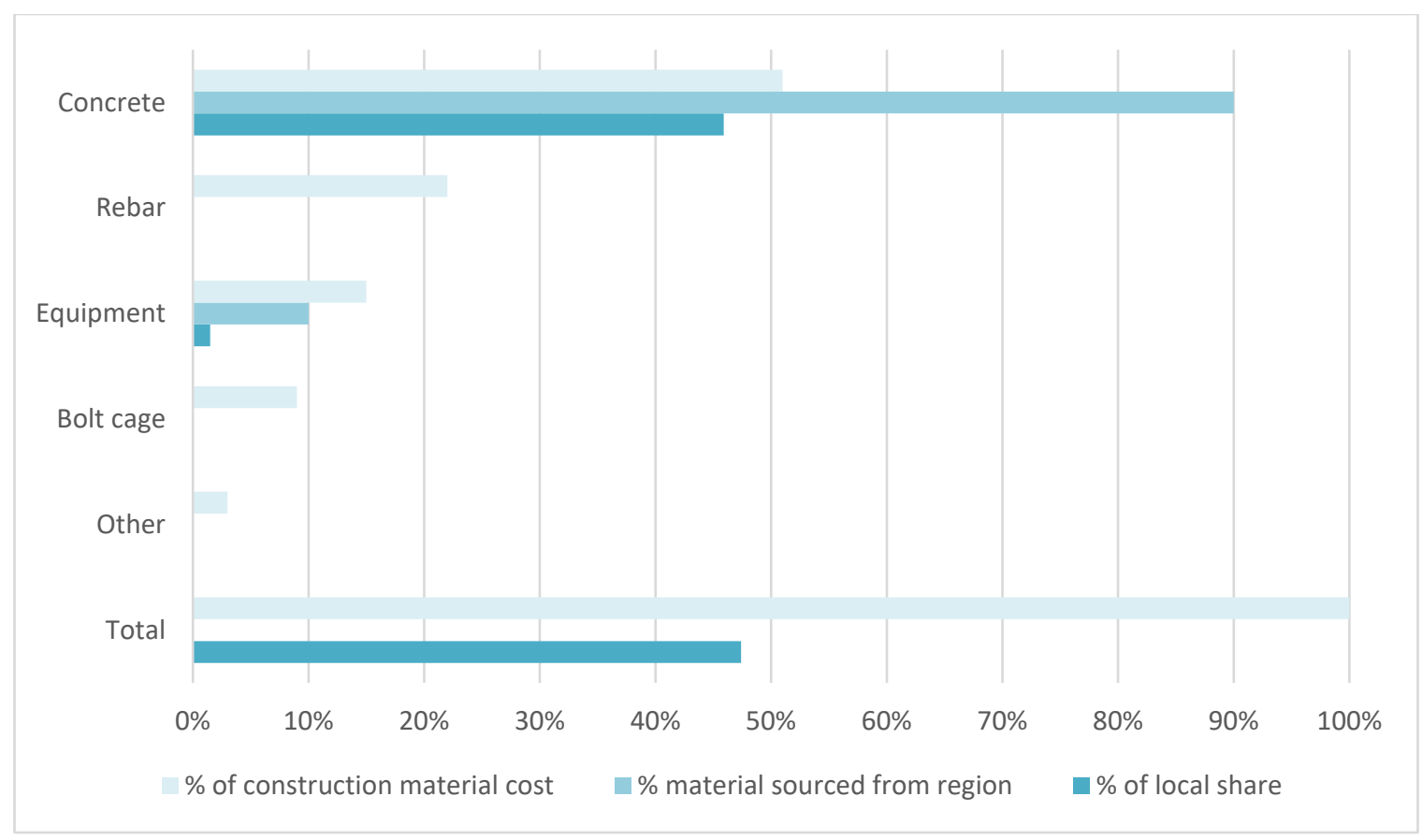

Figure 23. Four-county region Rush Creek Wind Farm construction materials expenditures

\subsubsection{Jobs and Earnings in Four-County Region During Construction Phase}

Researchers estimated that around $7 \%$ of foundation workers, $3 \%$ of electrical workers, and $3 \%$ of erection workers were residents of the four-county region. Interviews revealed that Mortenson hires local residents for direct jobs, such as foundation work, site security, and site cleanup, and hires local contractors to drive trucks, haul water, and supply fuel oil, among other jobs (see Table 8). Even so, large projects such as Rush Creek require employment bases larger than small counties can provide, and specialized positions such as crane operators, electricians, and management require labor outsourcing beyond the county or state.

Table 8. Four-County-Region Rush Creek Construction Contractors

\begin{tabular}{lll}
\hline Company & County & Service \\
\hline Hugo Lumber & Lincoln & Lumber and tool supply \\
\hline $\begin{array}{l}\text { Pronghorn ACE } \\
\begin{array}{l}\text { Rob's Septic Service and } \\
\text { Porta-Pot Rental }\end{array}\end{array}$ & Lincoln & Tooling supply \\
$\begin{array}{ll}\text { Stone Oil } \\
\begin{array}{l}\text { City of Limon Water } \\
\text { Department }\end{array}\end{array}$ & Lincoln & Site porta-pots and dumpsters \\
Halde Redi-Mix, Inc. & Lincoln & Project fuel \\
\hline
\end{tabular}


This research suggests that the Rush Creek Wind Farm supports approximately 620 FTE jobs in the four-county region, as shown in Figure 24. Of these jobs, 15 are on-site jobs, 545 are supply chain or contractor jobs, ${ }^{44}$ and 60 are induced jobs (jobs supported by expenditures by on-site and supply chain workers, such as restaurant and lodging staff). Findings align with interviews with community members and stakeholder organizations within the region.

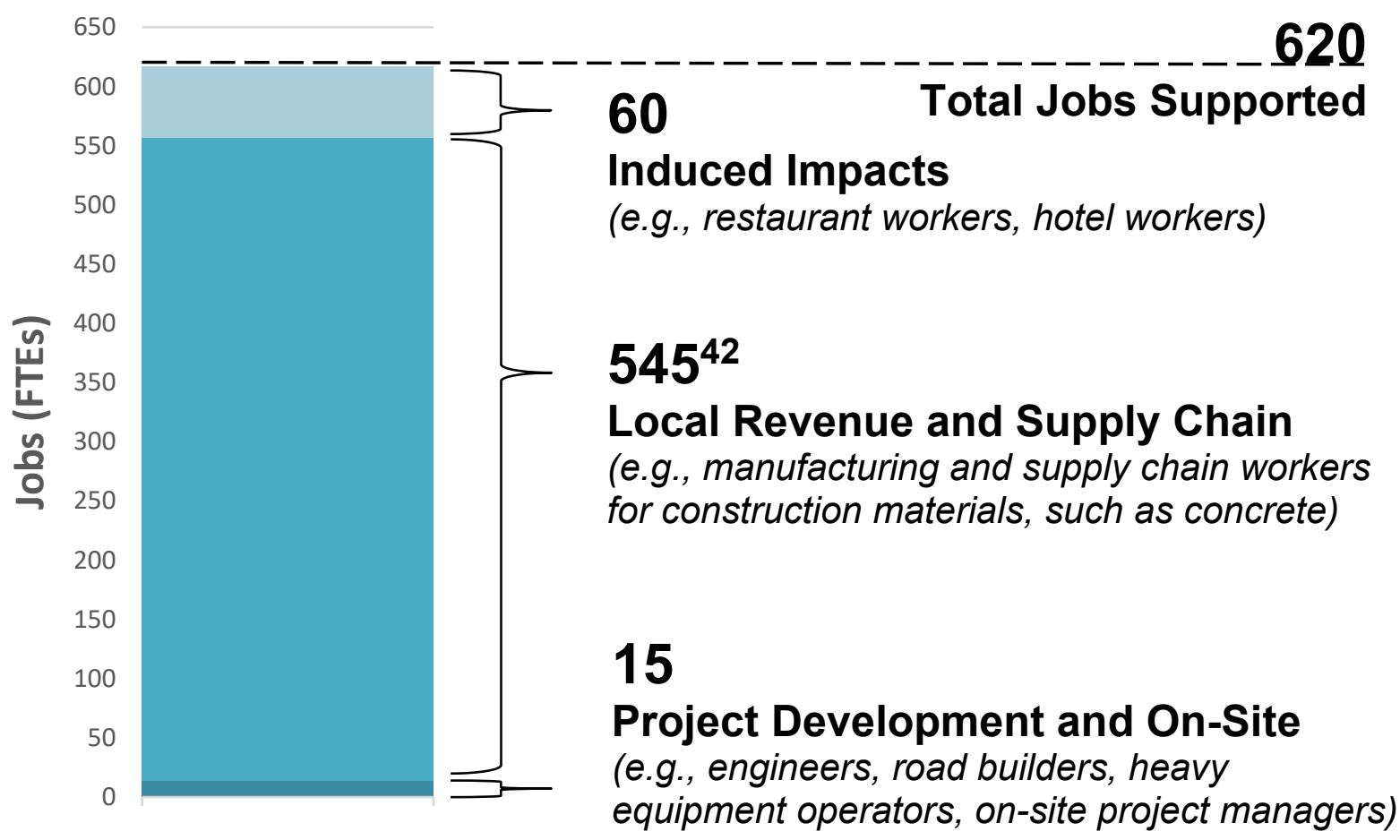

Figure 24. Four-county-region estimated jobs supported from Rush Creek construction

Table 9 summarizes the estimated earnings for workers during construction of Rush Creek in the four-county region. Workers in the Project Development and On-Site Labor category (e.g., engineers, road builders, heavy equipment operators, project managers) earned an average of approximately $\$ 68,000$ annually. Regional jobs that supply services of materials and supply chain impacts (e.g. construction subcontractors and professional subcontractors) earned an average of approximately $\$ 38,000$ annually. Induced impact jobs (e.g., hotel and restaurant workers) earned an average of approximately $\$ 28,000$ annually. The average wages for a worker within the four-county region is $\$ 39,403$ annually, about $4 \%$ higher than the average earnings from Rush Creek construction (BLS 2017).

\footnotetext{
${ }^{44}$ For the four-county region, local revenue and supply chain impacts are associated with spending on all materials that go into the construction of the plant, such as concrete and road maintenance. In addition, local revenue would include land easement and site certificate/permitting. This local revenue would have an indirect impact on the job estimates. These are high-cost inputs, and there are many interindustry spending patterns that may impact this result. These jobs are distributed over the entire construction life of the Rush Creek Wind Farm and would support, for example, road repair crews.
} 
Table 9. Estimated Four-County Region Average Earnings for Workers During Construction

\begin{tabular}{|c|c|}
\hline Impact & Average Earnings Per Worker ( $\$ /$ year) \\
\hline $\begin{array}{l}\text { Project Development and On-Site Labor } \\
\text { - Construction and Interconnection Labor } \\
\text { (e.g., engineers, road builders, heavy equipment } \\
\text { operators, project managers, construction workers) } \\
\text { - Construction-Related Services } \\
\text { (e.g., engineers, design, and other professional } \\
\text { services during development) }\end{array}$ & $\$ 68,000$ \\
\hline $\begin{array}{l}\text { Local Revenue and Supply-Chain-Related Labor } \\
\text { (e.g., manufacturing and supply chain workers for } \\
\text { construction materials) }\end{array}$ & $\$ 38,000$ \\
\hline $\begin{array}{l}\text { Induced Impacts } \\
\text { (e.g., restaurant workers, hotel workers) }\end{array}$ & $\$ 28,000$ \\
\hline Average Estimated Total Earnings & $\$ 38,000$ \\
\hline
\end{tabular}

\subsubsection{O\&M Phase}

During operating years, Rush Creek is expected to support jobs and economic activity in the four-county region, primarily through long-term, skilled O\&M jobs. According to Xcel Energy, the Rush Creek Wind Farm has an expected lifetime of 25 years. O\&M of Rush Creek will require the compensation of staff, including technicians, administrative assistants, and managers.

There are approximately 41 FTEs supported by the three wind farms (not including Rush Creek) near Limon, Colorado, which have a total nameplate capacity of $850 \mathrm{MW}$. Rush Creek will support additional O\&M workers in the community. An important consideration for the fourcounty region is ensuring O\&M jobs can be filled by local workers or workers who move into the region, enabling communities near Rush Creek to capture more of the economic impacts during the operating years. Many of the current O\&M workers supporting other wind developments commute from the metro Denver or Colorado Springs area, which causes a reduction in the induced impacts the community receives from workers living and working in the community. Local community leaders are developing solutions to attract more workers to Limon, Colorado, as detailed in Case Study: Economic Development in Rural America.

Based on O\&M costs, JEDI analysis estimates that approximately $\$ 2$ million of Rush Creek O\&M expenditures are spent within the four-county region annually. Local landowner leases and associated property taxes from Rush Creek are an estimated $\$ 108$ million over the 25 -year life of the project. This provides landowners with additional annual income and counties with a steady stream of tax revenue from the wind industry. 


\subsubsection{GDP Support in Four-County Region During O\&M Phase}

The Rush Creek Wind Farm supports approximately $\$ 6$ million in annual GDP to the fourcounty region (see Figure 25). On-site labor accounts for approximately $\$ 1$ million in annual GDP; $\$ 4.4$ million in annual GDP is realized through supply chain, landowner revenue, or business-to-business services. Induced impacts represent $\$ 0.6$ million in annual GDP.

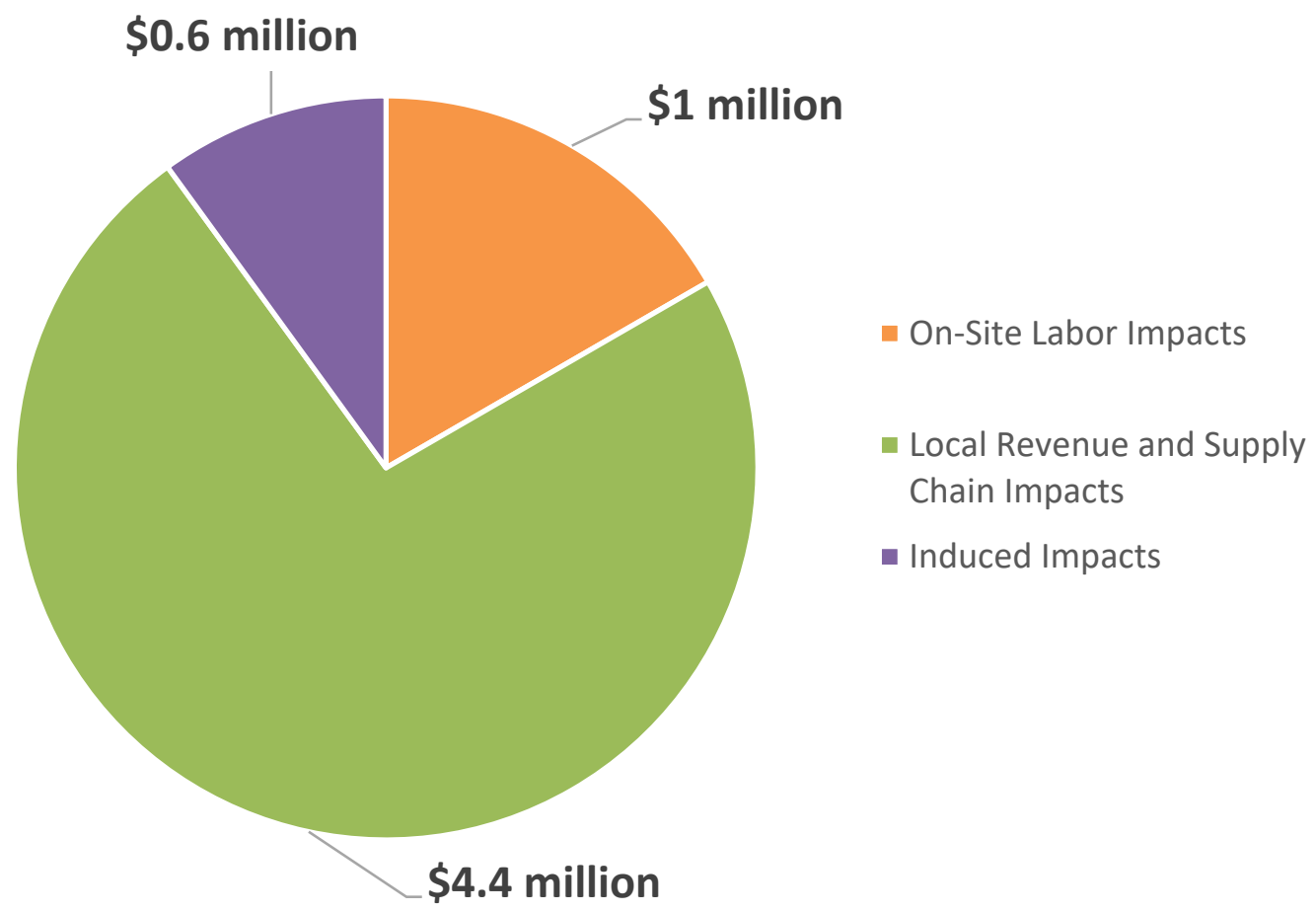

Figure 25. In the four-county region, Rush Creek is estimated to support \$6 million in GDP annually during operating years

\subsubsection{Gross Output in Four-County Region During O\&M Phase}

The Rush Creek Wind Farm supports approximately $\$ 9$ million in gross output annually in the four-county region (see Figure 26). On-site labor accounts for approximately $\$ 1$ million in economic activity. The Local Revenue and Supply Chain Impacts category accounts for approximately $\$ 7$ million in gross output, and the Induced Impacts category represents $\$ 1$ million in gross output. 


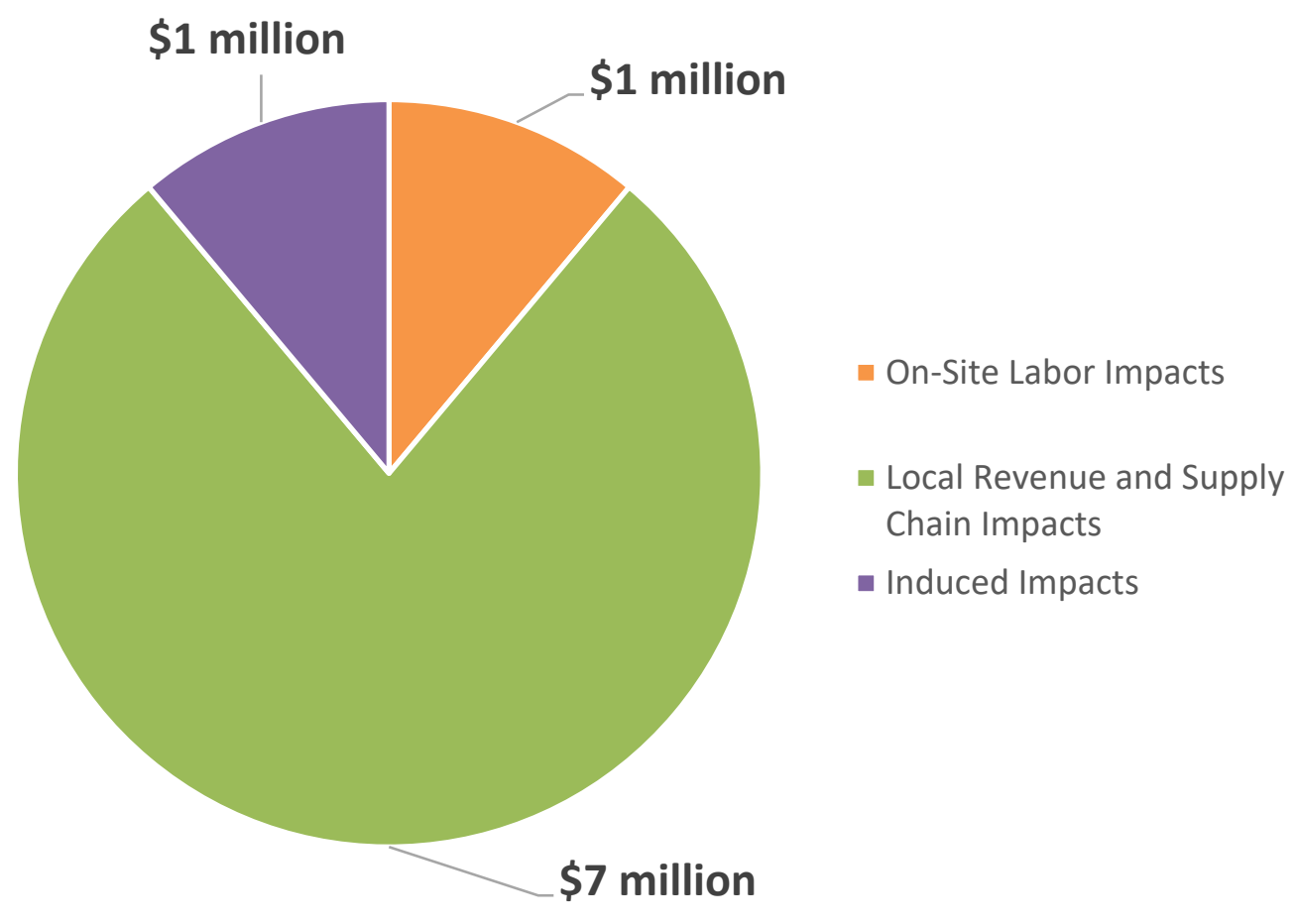

Figure 26. In the four-county region, Rush Creek is estimated to support $\$ 9$ million in gross economic output annually during operating years

\subsubsection{Jobs and Earnings in Four-County Region During O\&M Phase}

Wind farm O\&M generally supports full-time, long-term jobs. These positions include technicians, managers, and administrative workers; they do not include traveling technicians who perform more specialized repairs.

As noted earlier, interviews revealed that a high percentage of individuals who work in the region commute from the East Denver Metro Area or Colorado Springs. The LCEDC reported that $70 \%$ of employees of other local wind farms (Cedar Point and Limon I, II, II) commute from East Denver. Interviewees cited several reasons for this, including the local housing shortage, high local housing costs, and the desire to live in more urban areas. Researchers assumed $50 \%$ of the 24 on-site Rush Creek O\&M jobs, estimated by the JEDI model, live in the region and the other $50 \%$ of on-site workers commute from larger metropolitan areas nearby.

Research estimates that Rush Creek supports approximately 47 FTE ongoing jobs in the fourcounty region, as shown in Figure 27. Of these, 12 FTE jobs would be on-site positions directly involved with maintaining the wind farm, and 28 FTE jobs are local revenue and supply chain jobs, indirectly involved with the plant's operation. These include contractual services, manufacturing of equipment necessary for repair, and so on. Expenditures made by on-site and off-site workers support an additional seven long-term induced jobs in unrelated industries (e.g., RV parks, hotels, restaurants) providing local services or products. 


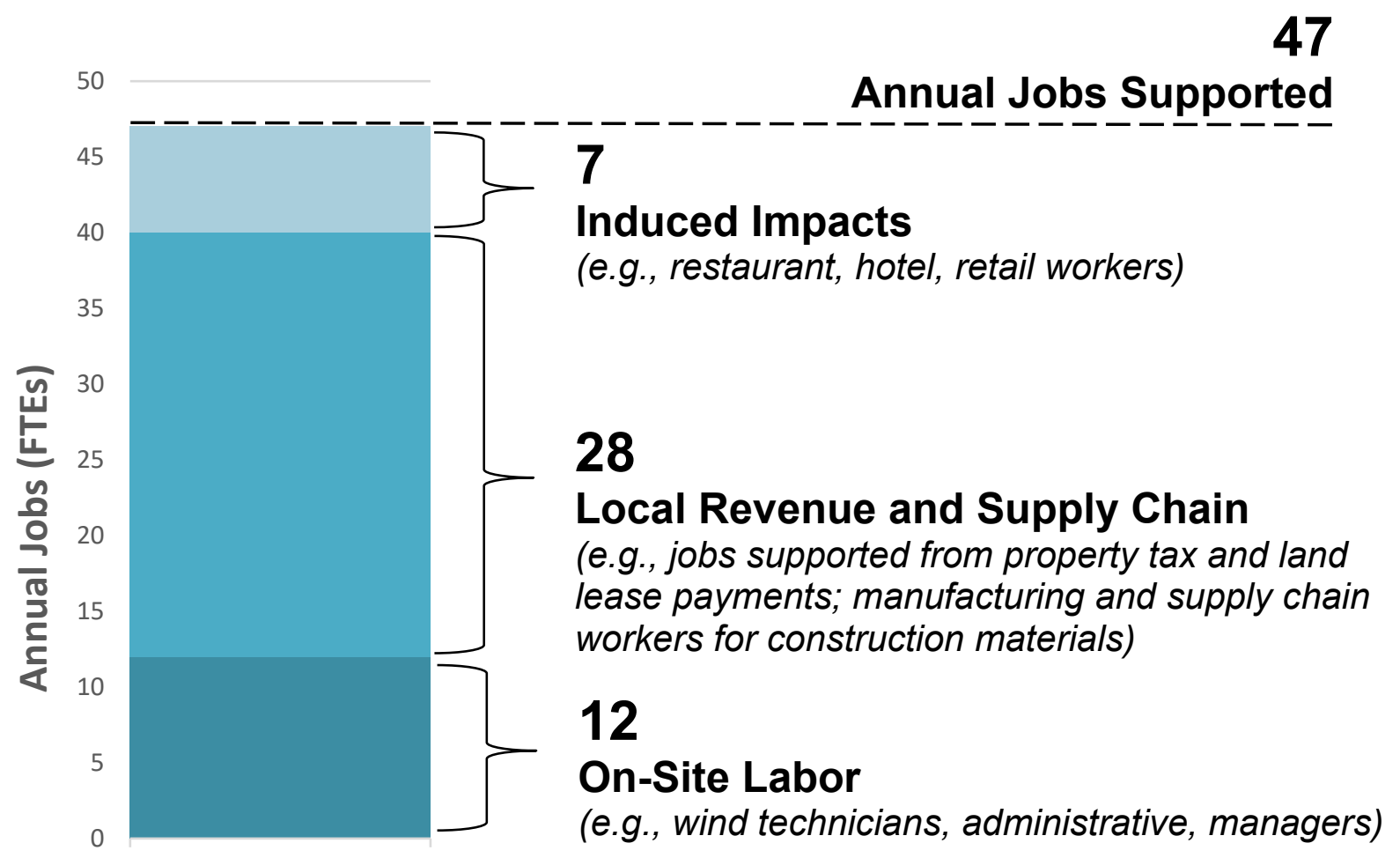

Figure 27. Four-county-region estimated annual ongoing jobs supported from Rush Creek O\&M

Table 10 summarizes the estimated earnings for workers in the four-county region based on job category during O\&M. On-site labor workers (e.g., wind technicians, managers) earn an average of approximately $\$ 76,000$ annually. Colorado supply chain jobs in the four-county region that supply construction materials and services (e.g., equipment repair) earned an average of approximately $\$ 32,000$ annually. Induced jobs (jobs supported by spending by O\&M workers) earned an average of approximately $\$ 34,000$ annually. The average estimated earnings for a worker within the four-county region supported by Rush Creek O\&M is $\$ 43,000$ annually.

Table 10. Estimated Four-County Region Average Earnings for Workers During O\&M

\begin{tabular}{ll}
\hline Impact & Average Earnings per Worker (\$/year) \\
\hline $\begin{array}{l}\text { On-Site Labor } \\
\text { (e.g., wind technicians, administrative, managers) }\end{array}$ & $\$ 76,000$ \\
\hline $\begin{array}{l}\text { Local Revenue and Supply-Chain-Related Labor } \\
\text { (e.g., jobs supported from property tax and land lease } \\
\text { payments; manufacturing and supply chain workers for }\end{array}$ & $\$ 32,000$ \\
O\&M materials and equipment) & \\
\hline $\begin{array}{l}\text { Induced Impacts (e.g., hotel, restaurant, retail workers) } \\
\text { Average Estimated Total Earnings }\end{array}$ & $\$ 34,000$ \\
\hline
\end{tabular}

Note: Totals may not sum due to rounding. Annual earnings, estimated by the JEDI model, include fringe benefits (i.e., supplemental costs paid by employers, such as health insurance and retirement). Earnings can also include nonwage compensation, such as proprietor earnings. 


\section{Case Study: Economic Development in Rural America Lincoln County Economic Development Corporation}

With a county population around 5,630 in eastern Colorado, Lincoln County is realizing the positive economic impacts from planning for growth of wind energy in the area. In addition to state-assessed property taxes, Lincoln County has a $2 \%$ sales-and-use tax levied on materials that are imported into the county. Because of the sales-and-use tax, the Rush Creek Wind Farm has contributed approximately $\$ 2.65$ million to Lincoln County. The county plans to add this revenue to the $\$ 6-\$ 7$ million the county has in reserves from wind and other energy development.

The LCEDC is seeking to pursue creative ways for wind energy development to continue growing their rural community's economy. Like many rural counties in America, Lincoln County faces the issue of finding a qualified local workforce as the population declines. Director Troy McCue estimates there are currently 41 FTE jobs in Lincoln County to support the O\&M of existing wind farms. However, he estimates that $70 \%$ of these employees are commuting from the East Denver metro or Colorado Springs areas. With an additional 15 to 18 FTEs expected from the O\&M future activity of the Rush Creek Wind Farm, the LCEDC is exploring ways to attract people to live and work in Lincoln County. The county is considering using the reserve money to build a new pool, fairground upgrades, and other community improvements. 


\section{Case Study: County Plans for the Future Elbert County, Colorado}

Elbert County collected approximately $\$ 4.2$ million in building permit fees during the development phase of the Rush Creek Wind Farm. This additional revenue was appropriated to help buffer against any future economic downturn.

County commissioners approved retaining approximately $\$ 500,000$ of the building permit fees into a contingency fund, which can be used for catastrophic or emergency events. In addition, the commissioners created a stabilization fund, using approximately $\$ 3.2$ million of the fees. This stabilization fund should allow the county to maintain normal operations and staffing levels during an economic downtown. This highlights an important theme heard in rural communities: the importance of planning ahead and creating funding mechanisms to support long-term sustainability. 


\subsection{Induced Impacts in the Four-County Region}

The JEDI model estimated 620 FTE jobs and \$36 million in GDP supported in the four-county region during the construction phase. While working in the region, construction contractors and subcontractors spend money on good and services and construction-related workers spend earnings, which causes induced impacts at businesses such as restaurants, lodging, and grocery stores. Specifically, these expenditures supported an estimated 60 regional FTE jobs and $\$ 5$ million in GDP during the construction phase.

Researchers were able to qualitatively verify that the communities near Rush Creek experienced induced impacts during Rush Creek construction despite being unable to quantitively validate how closely actual induced impacts match the JEDI model results. Interviews with local stakeholders provided real-world examples of how communities near the Rush Creek Wind Farm experienced induced impacts during the project's construction phase.

\subsubsection{Structured Interview Results}

Researchers conducted 18 structured interviews with local businesses in Lincoln County (see Figure 28) ${ }^{45}$ Business representatives were asked a predetermined list of 15 questions related to jobs and economic impacts they may have encountered during Rush Creek's construction phase. Representatives from businesses that experienced economic growth or changes in hiring practices were read a list of seven possible reasons for the increase and asked to select two. Interviewees signed a voluntary consent form, giving us permission to publish structured interview results while keeping their identities confidential. For the full list of interview questions and responses, see Appendix F.

Interviews reveal there are increased economic impacts in other industries (nonwind related) in Lincoln County that are supported by spending from Rush Creek construction workers. These interviews confirmed communities experienced induced impacts during wind farm construction, quantitatively modeled using JEDI in Section 3.3.

Figures 28-33 report the results of the structured interviews, which qualitatively summarize business attitudes regarding hiring, workloads, revenue, growth, and overall economic development in Lincoln County over the past year and the reasons for the changes. The past year is defined as a time period between fall 2016 and fall 2017, when structured interviews were completed. Based on the results of the structured interviews:

- Approximately $67 \%$ of businesses experienced increases in revenue from the previous year, with $11 \%$ seeing significant increases. Of these businesses, $58 \%$ selected Rush Creek as one of the factors contributing to revenue growth.

- Around $28 \%$ of respondents hired new people in the past year. Of these businesses, $80 \%$ attributed Rush Creek construction as one of the factors contributing to the need for new

\footnotetext{
${ }^{45}$ Researchers provided 62 businesses in Lincoln County with a set of questions and received 18 responses. See Section 2.2.1 for a methodology. These structured interviews inherently contain sampling, nonresponse, and measurement errors. Researchers made every effort to reduce this error. See Section 4.1.2 for a discussion on limitations of this methodology.
} 
hiring. Only a few businesses provided data on number of employees hired, which included 10 part time and five full time.

- Approximately $56 \%$ of employees worked more hours than last year. Of these businesses, $60 \%$ attributed increased hours worked to Rush Creek construction. A reason that more businesses are asking employees to work longer hours versus hiring new employees may be because of a shortage of a qualified workers in the region, which is discussed in Section 3.4.2.

- Although we were not able to secure a random scientific sample, structured interview respondents expressed support for wind development in their community. $50 \%$ of the interviewees strongly support wind development, around $22 \%$ moderately support wind development, and $28 \%$ were neutral. No respondents interviewed were opposed or strongly opposed to wind development in their communities.

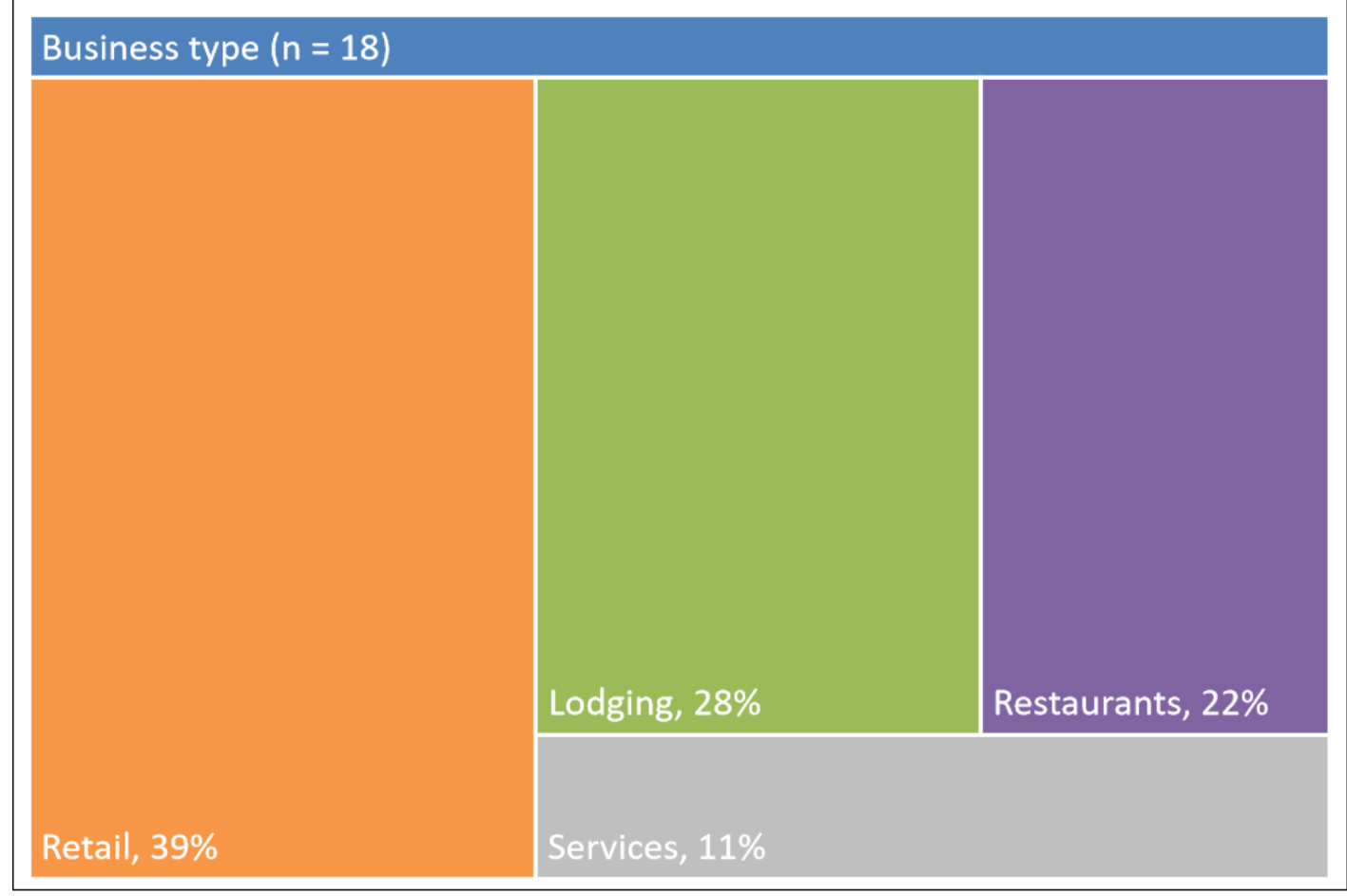

Figure 28. Breakdown of interview respondents by business type $(n=18)$ 


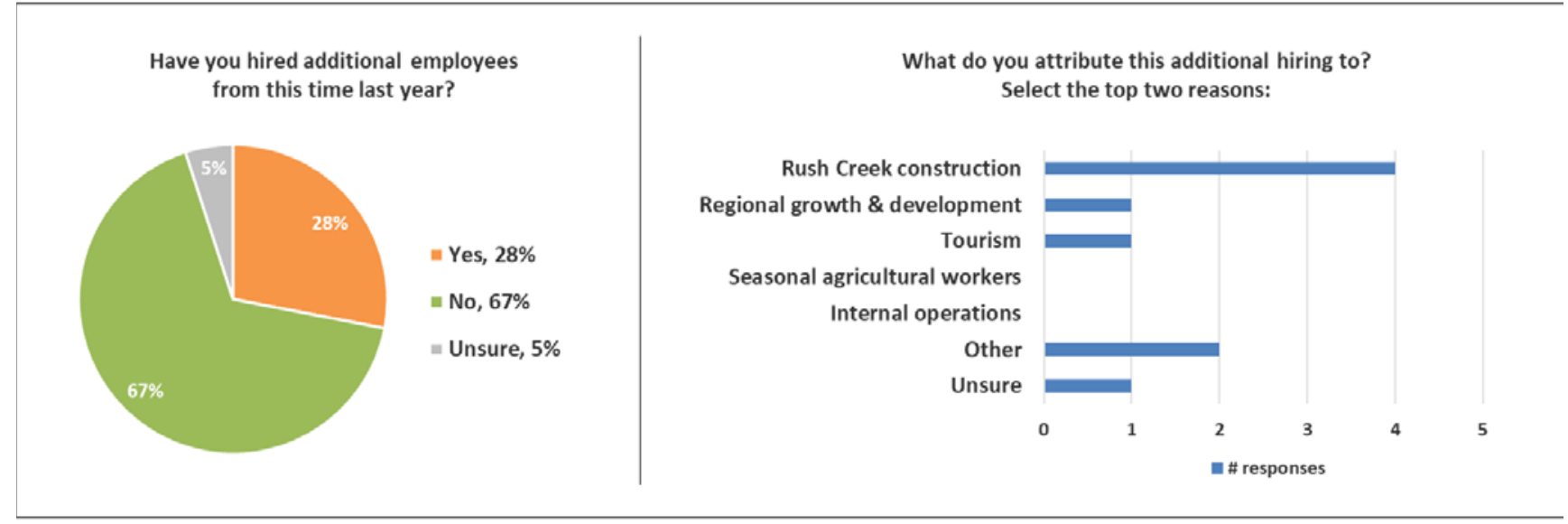

Figure 29. Lincoln County businesses hiring practices over the course of 1 year (during the Rush Creek Wind Farm construction)

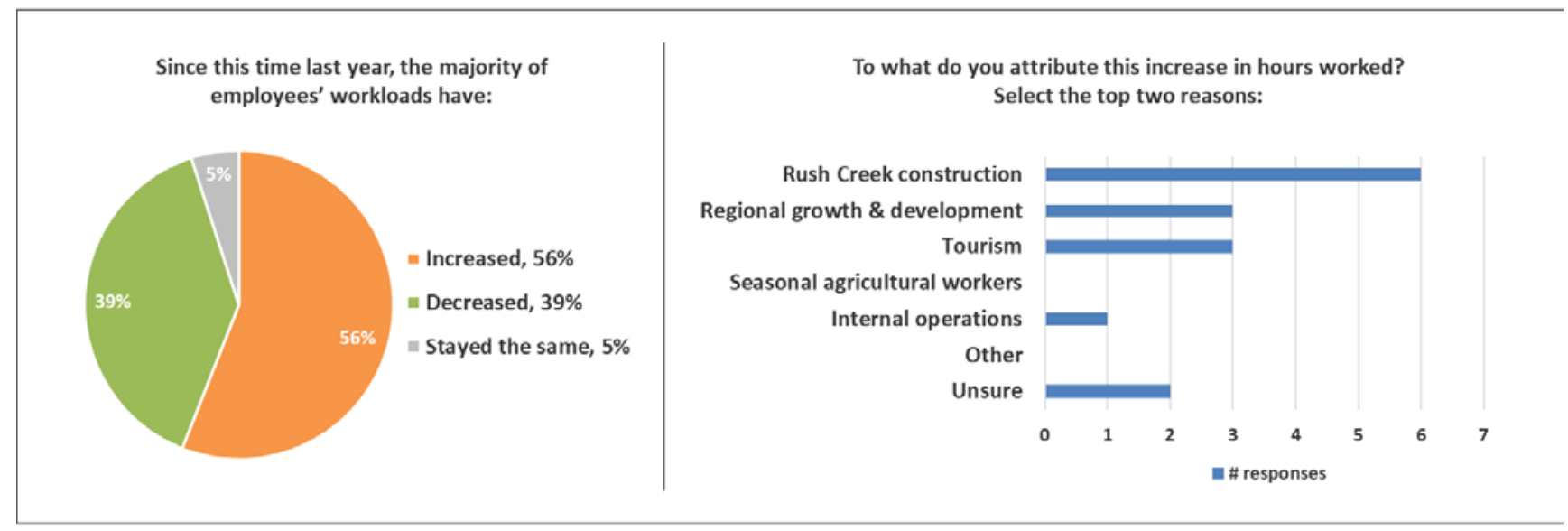

Figure 30. Workloads of Lincoln County businesses over the course of 1 year (during the Rush Creek Wind Farm construction) ${ }^{46}$

${ }^{46}$ Only businesses that indicated an increase in hours worked answered the question selecting two reasons to attribute this increase. If a respondent selected stayed the same or decreased, they skipped to the next question. 


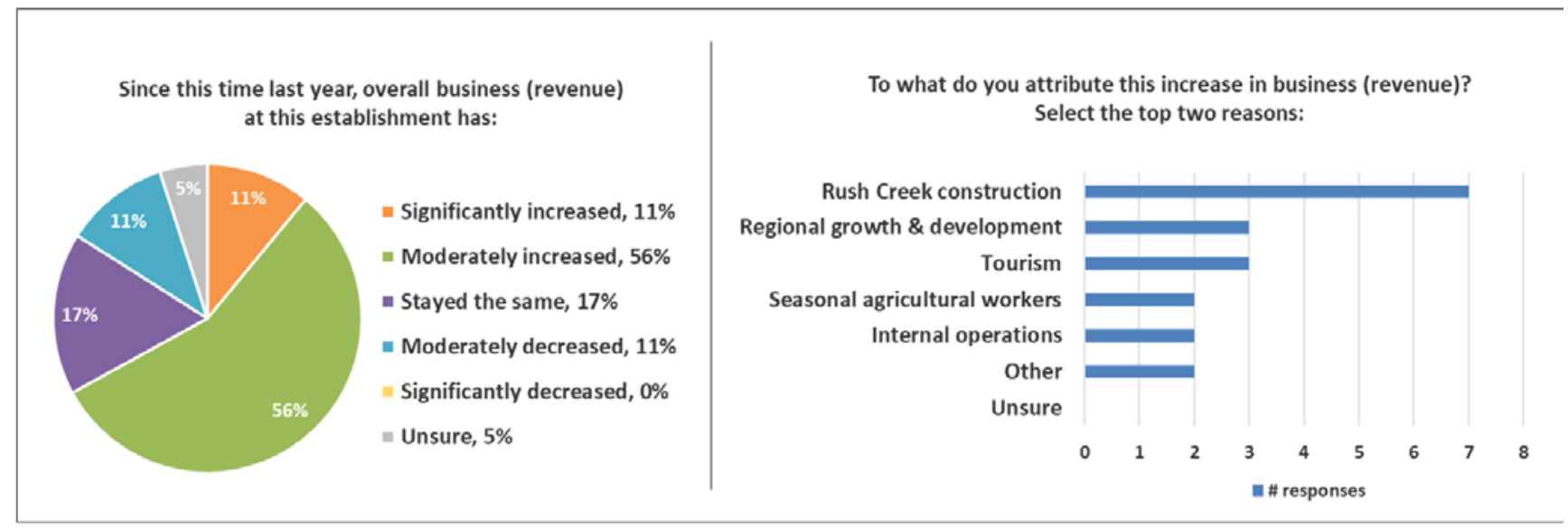

Figure 31. Lincoln County business revenue over the course of 1 year (during the Rush Creek Wind Farm construction) ${ }^{47}$

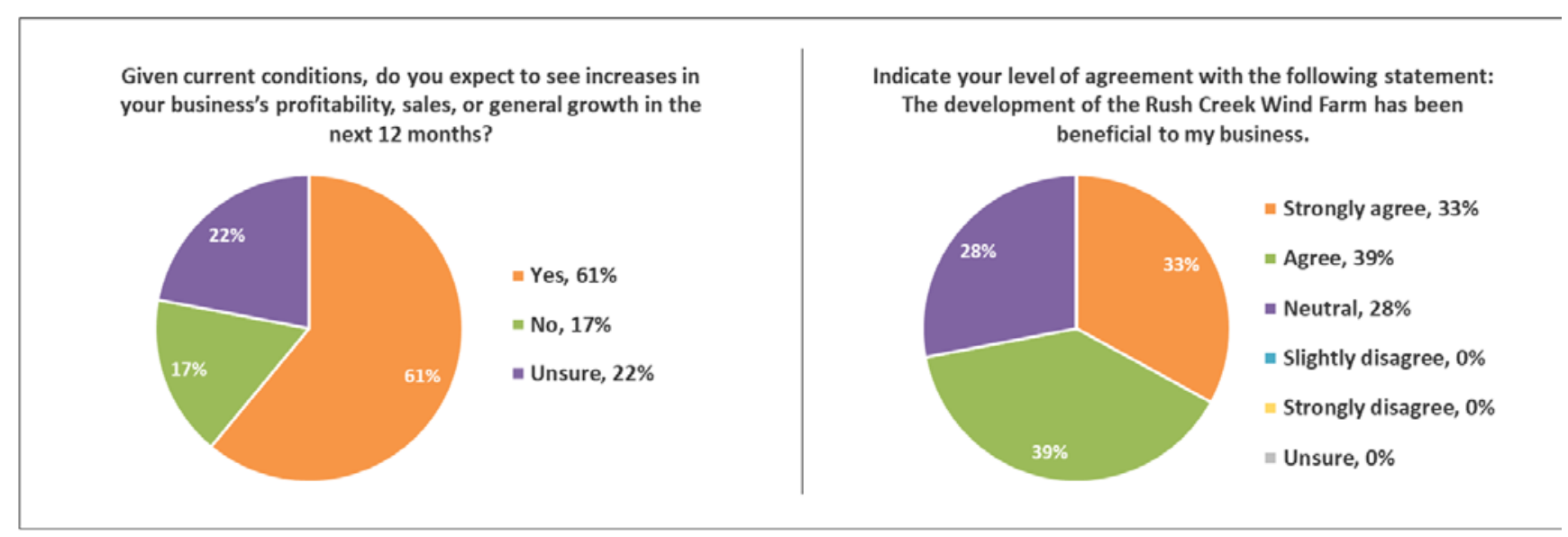

Figure 32. Lincoln County business owners/managers expected business growth in the next 12 months and the Rush Creek Wind Farm's impact on their businesses

\footnotetext{
${ }^{47}$ Only businesses that indicated an increase in business (revenue) answered the question selecting two reasons to attribute this increase. The respondent skipped to the next question if they selected stayed the same, decreased, or unsure.
} 


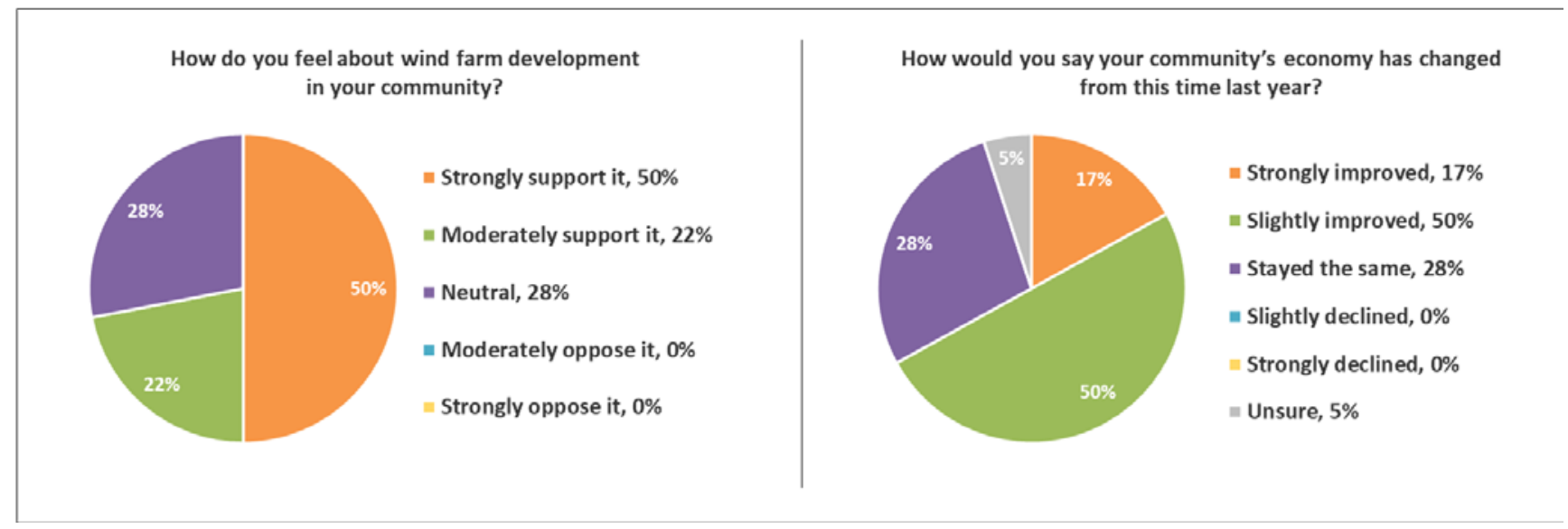

Figure 33. Lincoln County business owners'/managers' opinions of wind development in their community and how the local economy has changed in the past year (during the Rush Creek Wind Farm construction) ${ }^{48}$

48 There were no negative responses from business owners or managers to the questions regarding how the Rush Creek Wind Farm has impacted their local economy. 
Figure 34 lists responses from the structured interview questions. Responses are not attributed to a person or business to protect anonymity.

"I cannot overstate the importance of the Rush Creek project to Lincoln Co. or the Genoa, $\mathrm{CO}$ area. For many years our whole region will be impacted positively with the whole nation and world a better place."

"We need more projects like this to compensate for decreased oil and gas production."

"[The Rush Creek project] has caused housing shortage for locals and increases in rent, causing people to move out of area."

"[Operator] Need to get with the town to help with housing for people who are going to stay after project is done for the ones that will be staying here for the towers."

"[I] Have supported the wind farms. It [the wind farm] gives our farms money they can rely on. It [revenue] keeps some on the farm."

"There are only a few qualified workers in our area for new hires."

"The farm economy is depressed with commodity process being low. However, the wind farm should help fill in the losses from the agriculture downturn."

"Wind development is great for us during construction phase."

"Limon needs help to increase housing for when this project is done so your [Xcel] employees have a place to live and raise their families."

Figure 34. Additional structured interview comments from Limon business owners/managers

\subsubsection{Semistructured Interview Results}

Researchers conducted 21 semistructured interviews with individuals in towns surrounding Rush Creek. ${ }^{49}$ Semistructured interviews focused on exploring wind energy's impact on rural communities and potential economic effects from Rush Creek. Several relevant themes about wind development emerged from semistructured interviews that may be generally applicable for other wind farms being developed in rural areas, include the following:

- Regional housing shortage. During Rush Creek construction, approximately 200 to 300 people work on the project at one time. Interviews revealed that the influx of wind workers contributes to a housing shortage in the area. Also, an increase in demand for housing leads

\footnotetext{
${ }^{49}$ Researchers contacted several individuals based on their position within the county or organization and knowledge of the Rush Creek Wind Farm. Every effort was made to ensure a diverse sample, but responses were based on the willingness of the individual to participate. The opinions may not be representative of every community member but should be viewed as representative of the overall themes in the local community.
} 
to unusually high property prices in the region. An interviewee stated that he has seen onebedroom rentals in Limon listed for \$1,700 a month, much higher than Limon's past rental costs, which he states averaged about $\$ 500$ a month. As rentals fill with short-term construction workers, the housing shortage and increased prices discourage people who are looking for full-time residences from moving into the region. The housing shortages and increased prices are also causing locals who can no longer afford increased rental costs to move out of the area.

- Migration out of rural towns. Interviews revealed that attracting people to live and work in the four-county area is difficult. Young people are leaving small towns, such as Limon and Kiowa, for college and are not returning after graduation. An Elbert County commissioner said very few young/working-age individuals live in the eastern portion of the county; most residents are senior retirees. Although wind farm construction brings hundreds of workers into small rural towns, the rush is temporary; projects are usually completed within a year or two. However, wind farm O\&M provides long-term, steady jobs for the region. Community developers are trying to encourage Rush Creek O\&M workers to live in the area. LCEDC has plans to build more local housing and provide amenities to attract workers. Even with fewer specialized jobs outside of the wind industry, people are commuting an hour or more into the region for work. Interviews revealed that 6-7 employees carpool from the East Denver Metro area every day to work at a local fast food restaurant in Limon, because of the restaurant's inability to fill the positions locally.

- Shortages in the qualified local workforce. Local establishments expressed the need to hire additional employees to support increased business from Rush Creek construction workers. Although employers saw increased business as a positive, many local establishments found hiring qualified workers difficult. One business owner stated he has been trying to fill a position for a year but has not found someone capable of performing the job. A restaurant owner reported he needs to double his weekend workforce but has had a tough time finding and keeping qualified employees.

- Rural communities benefiting from wind development. Interviewees reported that the wind industry in their community supports the local economy and helps local businesses. During Rush Creek construction, hundreds of people are working on the project. These individuals are dining at local restaurants, staying in local motels and RV parks, and shopping at local grocery stores. An RV park owner in Lincoln County revealed that when he began managing the park in October 2017, he rented 3 to 22 lots; in January 2018, all 55 lots were booked. He reported that $75 \%$ of his lots are filled with Mortenson Construction workers who have signed 2-year contracts to stay. He, along with several other RV park owners, said they were expanding their operations to meet demand from wind workers. RV park owners expect that demand for lodging will stay high, even after Rush Creek is completed, as they are expecting future wind, solar, and road construction projects (see Case Study: Genoa RV Park).

- Expanded county economies. Counties are receiving additional revenue from wind development. Elbert County received $\$ 4.3$ million in one-time building permit fees from the construction of the Rush Creek Wind Farm. Elbert and Lincoln Counties are using fees and 
tax revenue from Rush Creek for infrastructure improvements and to put in a savings fund to help buffer the potential economic downturn effects. In addition, the four-county-region property tax revenue is estimated at $\$ 62.5$ million over the 25 -year life of the project. The LCEDC reported that their county prefers wind development because the property taxes provide a consistent income stream. Rush Creek Wind Farm will undergo a state-assessed evaluation each year over the plant's lifetime, with annual tax revenue distributed to counties.

- Expanded long-term income for property owners. Jan Kochis, a landowner in Elbert County, is reportedly receiving a land lease payment that is a percentage of gross production from turbines installed on the property. These landowner lease payments are a consistent revenue stream each year over the lifetime of the operating wind plant. Kochis reports that landowners can still farm and ranch with turbines on their property and additional income from turbines can help keep farmers and ranchers remain afloat when yield or commodity prices are low (see Case Study: Landowner Near Rush Creek Wind Farm).

- Longer-duration construction supports business. Representatives from local businesses and economic development organizations stated that the longer construction phase for wind development is one of the reasons they support Rush Creek. During this phase, many different types of workers supported construction-including foundation, electrical, erection, and management crews. Rush Creek construction lasted approximately 18 months. Other construction activities may move in and out of the community more quickly. The longer construction crews are present, the greater the potential for induced impacts from workers spending their earnings in communities. These workers spent earnings in Colorado and the four-county region near Rush Creek, supporting restaurants, lodging, grocery stores, and other retailers. 


\section{Case Study: Genoa RV Park, Supporting the Wind Industry and Rural America}

Large construction crews enter rural communities that are often unequipped to provide lodging to so many people. Construction workers must often stay long distances from the site. As a result, nearby towns miss out on increased business as workers spend money in the community. Rush Creek provided the perfect opportunity to test the Genoa RV Park business model: setting up RV parks in small communities to support the influx of wind construction workers while creating a new tax base for the community. Genoa, population $147,{ }^{50}$ was selected because of the town's proximity to Rush Creek and longer-than-50-year struggle with a shrinking population and loss of industry.

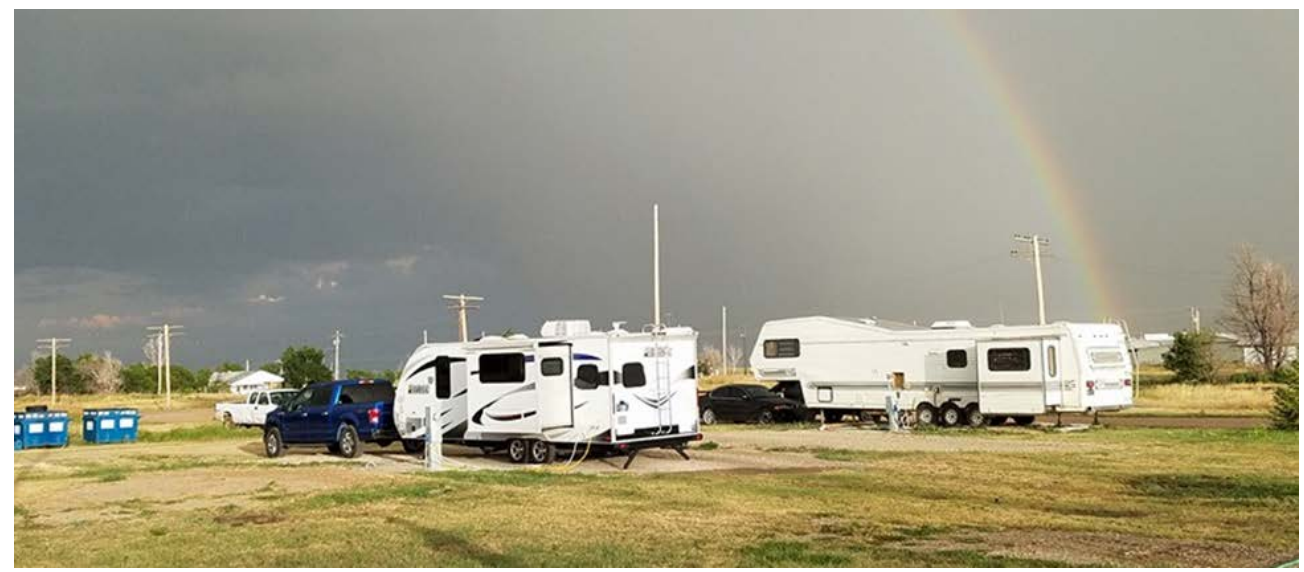

Figure 35. Genoa RV Park.

Photo from Genoa RV Park

Colorado resident Haden Lamb purchased an entire block in Genoa for the Genoa RV Park (see Figure 35), enough space for 12 short-term RV spots. The spots quickly filled with Rush Creek crane operators from Louisiana. Because of Genoa RV Park's early success, 21 additional RV spots were opened in town to support Rush Creek construction crews. Haden remodeled the historic building located on his property and opened a café inside-something, Haden boasts, "the city hasn't had in 25 years." The Genoa RV Park is supporting local jobs. Haden is hiring a cook for the café and a park manager. He is also hiring local construction crews to complete the RV park expansion and local contractors for electrical, plumbing, and trash pickup. Once the RV park is complete and self-sustaining, he has a deal with the city of Genoa to sell the park to the city. According to Haden, the Genoa RV Park is providing a much-needed tax base to the town and county. When asked why he chose to follow renewable energy, Haden said that he "wants to help give back to rural communities and support renewable energy development."

${ }^{50}$ U.S. Census Bureau (2017). 


\section{Research and Data Assumptions}

\subsection{JEDI Model}

This study uses NREL's Land-Based Wind JEDI model to analyze economic impacts from Rush Creek. JEDI is an input-output (I-O) model developed by MRG \& Associates and NREL to estimate the number of jobs, earnings, and overall economic activity supported by the construction and operation of a wind project at the state and county levels.

The JEDI model was used to estimate Rush Creek's economic impact to the state of Colorado, as well as the four-county region in which the project is located. The counties included in the region are Cheyenne, Elbert, Kit Carson, and Lincoln. The two project cost scenarios were modeled for both the state and region. The primary scenario represents the average cost of $\$ 1,164 / \mathrm{kW}$ for a 600-MW wind farm in similar parts of the United States and in similar terrain. The second scenario represents Xcel's Energy's projected project costs of $\$ 1,525 / \mathrm{kW}$, as disclosed to the PUC.

I-O modeling is a widely used methodology to trace interindustry relationships in an economy, demonstrating how output from one sector can become an input for another sector. I-O models map how economy sectors, such as businesses, households, workers, capital, and governments, interact with one another through expenditures at a single point in time (Tegen et al. 2014). For example, an increase in demand for towers can lead to an increase in demand for steel and other businesses supplying inputs to tower manufacturers. JEDI and other I-O models estimate economic impacts that are supported by changes in demand for goods and services. Relying on data from the project scenario, JEDI estimates a change in demand for these goods and services.

The JEDI project scenario is a set of data that describes a project. Each project contains two sets of line item expense categories, such as equipment (blades, towers, turbines), materials and services, and labor. One set covers the construction of the project, the other covers O\&M. JEDI models contain default project scenario and cost data, but analysts with knowledge of project details can edit these defaults to better represent the scenario being analyzed.

Key inputs to the model are the values for local share. This is the proportion of each line item that is supplied from within the area of interest. For example, the model allows users to specify whether wind turbine blades were manufactured in the state where the project is being built or outside the state (assuming the state is the region of analysis). JEDI uses expenditures made within the region of analysis, or "local expenditures," to estimate economic impacts. The local share specification can have a significant influence on model results. The JEDI model does not estimate economic impacts outside the region of analysis. For example, if a developer imports generator parts from China, the impacts that accrue in China would not be included.

\subsubsection{Limitations of the Model}

Like all economic models, there are limitations to JEDI. I-O models contain fixed and proportional relationships between industries. Similarly, household expenditures are fixed and proportional. This means that industries will purchase the same mix of goods to produce their output regardless of how much that output might change. Households will purchase the same proportional "basket" of goods regardless of how income might change. So, if a household 
spends $30 \%$ of their income on housing, the household will always spend $30 \%$ on housing regardless of how income might change, or a housing market might change as a result of a modeled scenario.

JEDI provides estimates of economic impacts for the user-specified expenditures data and economic conditions when I-O data were compiled. Impacts that extend into the future (such as O\&M impacts) are assumed to do so with all else held constant. There can be any number of changes in a dynamic economy that JEDI does not consider. Future results should not be considered a forecast but rather reflections of how a project might look if completed in the current economy under the user-specified cost and local share assumptions.

Results from JEDI models are gross, not net. JEDI only calculates what economic activity would be supported by demand created by project expenditures. Other changes in an economy may take place that JEDI does not consider. These changes may include price changes, changes in taxes or subsidies, utility rate changes, or changes in property values. JEDI also does not incorporate farreaching impacts, such as greenhouse gas emissions, displaced investment, or potential side effects of a project (e.g., changes in recreation or tourism).

Gross results also do not account for alternative uses of project funds such as investments in alternative technologies or spending elsewhere in the economy.

\subsubsection{Limitations of the Methodology}

The methodology used to collect quantitative data for the JEDI model and qualitative data for the community impact analysis has limitations.

NREL staff and management contacted many representatives at Xcel Energy and PSCo to assist with the cost input and local share information for the Rush Creek project. Xcel referred NREL staff back to public documents and did not discuss project costs, local share, or other information. Mortenson Construction also followed Xcel's lead and did not provide cost or other data. The category cost inputs in the JEDI model should not be viewed as actual costs incurred by Xcel but justifiable costs based on publicly available information and expert knowledge. Analysts assumed Xcel-reported costs contained contingency and other factors affecting the final cost of the Rush Creek Wind Farm. Local content percentages contain many assumptions based on community interviews and publicly available reports. Therefore, the jobs and economic impact results used in the JEDI model are representative of a typical 600-MW wind development in the interior of the United States.

The case studies presented throughout the report are based on interviews with counties, businesses, organizations, or individuals. The opinions may not be representative of every community member; instead, case studies should be viewed as representative of the overall themes in the local community.

Structured interviews inherently contain sampling, nonresponse, and measurement errors (Dillman 2009). Researchers made every effort to reduce this error to produce accurate information. Further, they conducted structured interviews with all businesses in Lincoln County impacted by wind energy to reduce coverage error. To determine the list impacted by wind energy, researchers created a list of all business in Lincoln County and removed a business not 
related to lodging, restaurants, retail, or wind-related service (e.g. nursing home). The sample size is small, thereby increasing the probability of sampling error. To reduce nonresponse error, researchers used a mixed-mode approach to distribute interviews. Researchers also designed the questions to be easily accessible to multiple businesses to reduce measurement error.

\subsection{Quantitative Data}

The JEDI model includes data from construction (i.e., equipment and balance of plant); operation and maintenance (i.e., labor, materials, and services); and other parameters (i.e., financial, tax, land lease, and payroll). Cost, local share, and the multipliers are the primary model inputs.

The four JEDI model scenarios for the Rush Creek project are:

1. Colorado state level at $\$ 1,164 / \mathrm{kW}$ total installed project cost

2. Colorado state level at $\$ 1,525 / \mathrm{kW}$ total installed project cost

3. Four-county region at $\$ 1,164 / \mathrm{kW}$ total installed project cost

4. Four-county region at $\$ 1,525 / \mathrm{kW}$ total installed project cost.

The primary results presented in the body of this report are based on scenarios 1 and 3. Results for scenarios 2 and 4 are in Appendix D.

The first and third JEDI model scenarios use BOP costs reported in NREL's 2016 Cost of Wind Review and turbine costs in the 2017 Wind Technologies Market Report. The $\$ 1,164 / \mathrm{kW}$ installed project cost does not include financing costs as the JEDI model incorporates these costs under other parameters. Installed project costs are $\$ 1,164 / \mathrm{kW}$ and O\&M costs reported are $\$ 43.60$.

The second and fourth scenarios are based on cost data submitted by Xcel Energy to the Colorado PUC. Xcel reported a total cost of the Rush Creek Wind Farm of $\$ 915$ million or an installed project cost of $\$ 1,525 / \mathrm{kW}$. Expected O\&M costs are $\$ 46.30 / \mathrm{kW}$, which were calculated from Xcel data provided to the PUC.

Based on discussions with technical experts, the installed project cost of $\$ 1,525 / \mathrm{kW}$ is higher than would be expected for a wind farm in the interior of the United States with a high nameplate capacity. Data tables for the $\$ 1,525 / \mathrm{kW}$ installed project costs and $\$ 46.30 / \mathrm{kW}$ O\&M scenario are included in Appendix B.

To account for possible contingency and overhead increasing the Xcel-reported project costs, $\$ 1,164 / \mathrm{kW}$ is modeled as an alternative installed project cost for the Rush Creek Wind Farm. Primary results are based on the conservative $\$ 1,164 / \mathrm{kW}$ scenario from market data. A JEDI analysis was completed at the Colorado state level and the four-county region. Data tables and assumptions for the primary results are outlined in this section. Table 11 includes the descriptive data used in the JEDI model. 
Table 11. Rush Creek Wind Farm Descriptive Data for JEDI Model

\begin{tabular}{ll}
\hline Input & Data \\
\hline Project Location & $\begin{array}{l}\text { State level: Colorado } \\
\text { Four-county region: Elbert, Lincoln, Kit Carson, } \\
\text { Cheyenne Counties }\end{array}$ \\
\hline Construction Year & 2018 \\
\hline Money Value (Dollar Year) & 2016 \\
\hline Nameplate Capacity & $600 \mathrm{MW}$ \\
\hline Number of Turbines & 300 \\
\hline Turbine Size & $2,000 \mathrm{~kW}$ \\
\hline Total Capital Cost & $\$ 698,137,648$ \\
\hline Installed Project Cost & $\$ 1,164 / \mathrm{kW}$ \\
\hline Operation and Maintenance Cost & $\$ 43.60 / \mathrm{kW}$ \\
\hline
\end{tabular}

JEDI model inputs consist of detailed cost information, often considered proprietary. Attempts to gain actual project costs from Xcel were unsuccessful. However, documents and testimonies submitted to the PUC by Xcel Energy during assessment of the Rush Creek project provided several known JEDI inputs. To overcome data gaps, default JEDI model cost percentages were used to extrapolate unknown costs from known project costs. An extensive literature review was conducted to ensure these costs are representative of wind projects like Rush Creek-including industry trend reports, corporate press releases, and media reports. Researchers also discussed wind farm costs with project experts. This extensive review verified JEDI inputs used for construction and operating costs.

Local share percentages were derived from comprehensive interviews and research. For wind turbine components (i.e., turbine, tower, blades), the wind manufacturing sector was analyzed in Colorado. Researchers visited the Vestas manufacturing plants for nacelles, blades, and towers. Researchers also investigated the current supply chain that supports turbine manufacturing in Colorado. Data attained included workforce information and the source of parts and materials used during in-state wind turbine assembly.

From discussions with construction suppliers and the BVEM reports submitted to the PUC by Xcel Energy, researchers derived local share percentages for BOP materials and labor.

To determine other local share percentages and cost data, researchers conducted extensive interviews with industry experts, country commissioners, a workforce center, an economic development corporation, a landowner, and other stakeholders to provide further depth into the analysis. This provided information about average wind development costs, country tax revenues, land lease payments, and local share of Rush Creek-related construction employment, equipment, and materials.

The data for the primary JEDI model inputs representing current turbine cost assumptionsincluding equipment, balance of plant, O\&M, and other parameters - are detailed in this section. 


\subsubsection{Equipment Costs and Local Share}

The equipment category in the JEDI model includes the cost and local share to manufacture turbines (i.e., nacelles), towers, and blades as well as transportation costs by truck from Colorado-based Vestas manufacturing plants to the wind farm in eastern Colorado. Table 12 outlines the turbine-related inputs for an installed project cost of $\$ 1,164 / \mathrm{kW}$.

Table 12. JEDI Model Equipment Costs for State Level and Four-County Region

\begin{tabular}{lllll}
\hline Equipment & Cost $\mathbf{\$}$ \$) & $\begin{array}{l}\text { Cost } \\
\text { per kW }\end{array}$ & $\begin{array}{l}\text { \% of Total } \\
\text { Project Cost }\end{array}$ & Source \\
\hline $\begin{array}{l}\text { Turbines (excluding } \\
\text { blades and towers) }\end{array}$ & $\$ 236,640,000$ & $\$ 394$ & $33.9 \%$ & \\
\hline Blades & $\$ 135,798,319$ & $\$ 226$ & $19.5 \%$ & $\begin{array}{l}\text { 2016 Cost of Wind Energy } \\
\text { Review }\end{array}$ \\
\hline Towers & $\$ 107,563,025$ & $\$ 179$ & $15.4 \%$ & WISDEM \\
\hline Transportation & $\$ 21,329,763$ & $\$ 36$ & $3.1 \%$ & 2017 Wind Technologies \\
\hline Equipment Total & $\$ \mathbf{5 0 1 , 3 3 1 , 1 0 8}$ & $\mathbf{\$ 8 3 6}$ & $\mathbf{7 1 . 8 \%}$ & Market Report \\
\hline
\end{tabular}

\section{Equipment Costs}

Researchers were not provided with the turbine sales agreement contract price between Xcel Energy and Vestas Energy. To determine cost inputs for equipment, researchers completed an extensive literature review and held discussions with technical experts. The average price for U.S. wind turbine transactions ranges between $\$ 800 / \mathrm{kW}$ and $\$ 1,100 / \mathrm{kW}$ (Wiser and Bolinger 2017). Based on the number of turbines purchased for the Rush Creek project and the current turbine market conditions, $\$ 800 / \mathrm{kW}$ was determined to be a reasonable turbine cost assumption. For transportation, Rush Creek turbines were delivered by truck. The farthest plant from Rush Creek is 150 miles; $\$ 836 / \mathrm{kW}$ is the JEDI model equipment costs, including transportation.

To scale the equipment costs to $\$ 800 / \mathrm{kW}$, researchers relied on a previous review of wind energy costs (Stehly et al. 2017). The 2016 Cost of Wind Energy Review details component-level costs based on recent market data and state-of-the-art modeling capabilities. The report breakdown for a 2.16-MW land-based turbine for rotor, nacelles, and towers is approximately $28 \%, 49 \%$, and $22 \%$ of the total turbine cost, respectively. These percentages provide the breakdown for equipment costs.

\section{Equipment Local Share}

This economic analysis of the Rush Creek Wind Farm is the first JEDI analysis undertaken wherein turbine equipment was assembled or manufactured in state. Local share is the percentage of expenditure spent in the state or local region where the plant is constructed. To determine a reasonable Colorado local share for the turbine costs, researchers used cost breakdowns outlined in the U.S. Wind Energy Manufacturing and Supply Chain: A Competitiveness Analysis (GLWN 2014). Costs were detailed for the specific materials used in towers and blades as well as total manufacturing cost, including labor, burden, sales, engineering, logistics, and profit. 
Researchers investigated the current status of wind manufacturing in Colorado, including the OEM (Vestas Wind Energy) and wind-related supply chain, which provides subcomponents, parts, and materials. Interviews with Vestas provided information on the source of parts and materials for blade and tower manufacturing and nacelle assembly. Local share percentages are a weighted average of the parts or materials in the turbine equipment multiplied by the percentage sourced from Colorado. Detailed local share calculations for equipment costs are included in Appendix E. Although nacelles were not included in the previously mentioned referenced report, a similar methodology was used to calculate a local share percentage for nacelles.

At the four-county region, there are currently no wind manufacturing or related supply chain participants. Therefore, local share input at the four-county region was $0 \%$. Table 13 outlines the local share inputs modeled at the state and four-county level for equipment costs.

Table 13. Equipment Local Share Modeled in JEDI for Rush Creek

\begin{tabular}{lll}
\hline Equipment & $\begin{array}{l}\text { State-Level } \\
\text { Local Share }\end{array}$ & $\begin{array}{l}\text { Four-County Region } \\
\text { Local Share }\end{array}$ \\
\hline Turbines (excluding blades and towers) & $16 \%$ & $0 \%$ \\
\hline Blades & $66 \%$ & $0 \%$ \\
\hline Towers & $37 \%$ & $0 \%$ \\
\hline Transportation & $50 \%$ & $0 \%$ \\
\hline
\end{tabular}

\section{Transportation}

Transportation costs were modeled using propriety data from NREL's WISDEM model. ${ }^{51}$ Researchers learned during interviews with stakeholders that equipment would be trucked to the Rush Creek Wind Farm site. Although equipment could be transported from any of Colorado's Vestas plants, at approximately 150 miles, the blade facility in Windsor, Colorado, is the farthest distance from the Rush Creek site. Local share percentages for transportation are based on discussions with representatives from Vestas and the wind-related supply chain. Vestas does not rely solely on Colorado trucking companies for blade, tower, and nacelle deliveries. However, based on potential for Vestas to use a Colorado-based trucking company to deliver equipment to Rush Creek, a 50\% local share was modeled for transportation.

\subsubsection{Balance of Plant Costs and Local Share}

BOP costs and local share percentages are based on information provided in documents and testimonies filed by Xcel Energy to Colorado's PUC, interviews of knowledgeable stakeholders, NREL's WISDEM cost model, ${ }^{44}$ and JEDI model defaults. Accounting for the $\$ 800 / \mathrm{kW}$ turbine costs, the remaining BOP cost is $\$ 321 / \mathrm{kW}$. Local share percentages are identical for the statelevel model run but differ for the four-county region.

\footnotetext{
${ }^{51}$ Documentation about WISDEM and a download of the models are available at https://nwtc.nrel.gov/content/wisdem-software-documentation.
} 


\section{BOP Costs}

Table 14 outlines the costs and source of the cost data for our results. The state-level and fourcounty region $\mathrm{BOP}$ costs are the same.

Table 14. \$1,164/kW Balance of Plant Costs Modeled in JEDI for Rush Creek

\begin{tabular}{|c|c|c|c|c|}
\hline Balance of Plant & Cost & $\begin{array}{l}\text { Cost per } \\
\text { kW }\end{array}$ & $\begin{array}{l}\% \text { of Total } \\
\text { Project Cost }\end{array}$ & Source \\
\hline \multicolumn{5}{|l|}{ Materials } \\
\hline $\begin{array}{l}\text { Construction (concrete, rebar, } \\
\text { equip, roads, and site prep) }\end{array}$ & $\$ 83,668,853$ & $\$ 139$ & $12.0 \%$ & JEDI model \\
\hline Transformer & $\$ 15,000,000$ & $\$ 25$ & $2.1 \%$ & Xcel-PUC filing \\
\hline Electrical (drop cable, wire) & $\$ 9,976,414$ & $\$ 17$ & $1.4 \%$ & JEDI model \\
\hline High-voltage line extension & $\$ 0$ & $\$ 0$ & $0.0 \%$ & Xcel-PUC filing \\
\hline Materials subtotal & $\$ 108,645,267$ & $\$ 181$ & $15.6 \%$ & \\
\hline \multicolumn{5}{|l|}{ Labor } \\
\hline Foundation & $\$ 5,967,809$ & $\$ 10$ & $0.9 \%$ & JEDI model \\
\hline Erection & $\$ 6,759,390$ & $\$ 11$ & $1.0 \%$ & JEDI model \\
\hline Electrical & $\$ 9,850,467$ & $\$ 16$ & $1.4 \%$ & JEDI model \\
\hline Management/supervision & $\$ 5,111,426$ & $\$ 9$ & $0.7 \%$ & JEDI model \\
\hline Misc. & $\$ 29,596,464$ & $\$ 49$ & $4.2 \%$ & JEDI model \\
\hline Labor subtotal & $\$ 57,285,556$ & $\$ 95$ & $8.2 \%$ & \\
\hline
\end{tabular}

\section{Development/Other Costs}

High-voltage sub/interconnection

\begin{tabular}{|c|c|c|c|c|}
\hline Materials & $\$ 5,750,240$ & $\$ 10$ & $0.8 \%$ & JEDI model \\
\hline Labor & $\$ 1,761,412$ & $\$ 3$ & $0.3 \%$ & JEDI model \\
\hline Engineering & $\$ 6,702,300$ & $\$ 11$ & $1.0 \%$ & WISDEM \\
\hline Legal services & $\$ 4,264,428$ & $\$ 7$ & $0.6 \%$ & JEDI model \\
\hline Land easements & $\$ 4,275,000$ & $\$ 7$ & $0.6 \%$ & Stakeholder interview \\
\hline Site certificate/permitting & $\$ 4,000,000$ & $\$ 7$ & $0.6 \%$ & Xcel-PUC filing \\
\hline Development/other subtotal & $\$ 26,753,380$ & $\$ 45$ & $3.8 \%$ & \\
\hline Balance of Plant Total & $\$ 192,684,203$ & $\$ 321$ & $27.6 \%$ & \\
\hline Sales tax & $\$ 4,122,338$ & $\$ 7$ & $0.6 \%$ & \\
\hline
\end{tabular}

Costs that were detailed in Xcel-PUC filings or obtained during interviews with knowledgeable stakeholders were input into the JEDI model as actual costs. Other cost categories not specifically referenced were based on JEDI model defaults.

Transformer costs were reported in the direct testimony of Riley Hill to the PUC (Hill 2016). This cost category includes the cost of the equipment at the substation to step up the voltage of 
the electricity generated at the wind plant. This does not include transformers at the base of the wind turbines because that equipment is included in turbine costs.

A new 83-mile, 345-kV transmission line is being constructed for the Rush Creek project, at a reported cost of $\$ 121$ million (Hill 2016). Because of the size and cost of this transmission line project, these costs were not included in the Rush Creek economic analysis. To better estimate the economic development impacts associated with the transmission line project, a follow-on study could model the transmission line costs using NREL's JEDI Transmission Line model.

Engineering costs were calculated from propriety data in the WISDEM model. This model scales costs based on the size of the wind development. In addition, the costs associated with preoperation land easements were calculated using information gathered during an interview with a landowner who has turbines installed on her property. Site certificate/permitting costs were obtained from reviewing the BVEM status report.

BOP costs listed as JEDI defaults were calculated by removing the "known" costs from the model and redistributing the remaining costs to JEDI default values. This allowed the JEDI model to appropriately scale costs to line items that could not be verified in PUC filings. All default costs in the JEDI model scenarios were reviewed by technical experts to ensure they are representative of expected BOP costs during construction of the Rush Creek Wind Farm.

\section{BOP Local Share}

The local share percentages for BOP are based on information provided in documents and testimonies filed by Xcel Energy to Colorado's PUC, interviews of knowledgeable stakeholders, and JEDI model default inputs. Local share at the state level is defined as any materials or labor that are sourced from Colorado. Local share percentages at the four-county level are based on expected expenditures in the four-county region. Table 15 lists the BOP local share at the state level and four-county region. 
Table 15. Balance-of-Plant Local Share Inputs for Rush Creek JEDI Model

\begin{tabular}{|c|c|c|}
\hline Balance of Plant & $\begin{array}{l}\text { State-Level } \\
\text { Local Share }\end{array}$ & $\begin{array}{l}\text { Four-County Region } \\
\text { Local Share }\end{array}$ \\
\hline \multicolumn{3}{|l|}{ Materials } \\
\hline $\begin{array}{l}\text { Construction (concrete, rebar, } \\
\text { equipment, roads, and site } \\
\text { preparation) }\end{array}$ & $90 \%$ & $47 \%$ \\
\hline Transformer & $0 \%$ & $0 \%$ \\
\hline Electrical (drop cable, wire) & $50 \%$ & $0 \%$ \\
\hline High-voltage (HV) line extension & $0 \%$ & $0 \%$ \\
\hline \multicolumn{3}{|l|}{ Labor } \\
\hline Foundation & $80 \%$ & $7 \%$ \\
\hline Erection & $40 \%$ & $3 \%$ \\
\hline Electrical & $80 \%$ & $3 \%$ \\
\hline Management/supervision & $50 \%$ & $0 \%$ \\
\hline Misc. & $50 \%$ & $50 \%$ \\
\hline \multicolumn{3}{|l|}{ Development/Other Costs } \\
\hline \multicolumn{3}{|l|}{ HV sub/interconnection } \\
\hline Materials & $90 \%$ & $0 \%$ \\
\hline Labor & $100 \%$ & $2 \%$ \\
\hline Engineering & $65 \%$ & $0 \%$ \\
\hline Legal services & $65 \%$ & $1 \%$ \\
\hline Land easements & $100 \%$ & $100 \%$ \\
\hline Site certificate/permitting & $100 \%$ & $100 \%$ \\
\hline
\end{tabular}

Researchers calculated BOP local shares percentages using several lines of evidence. A construction local share was calculated based on the percentage breakdown of construction material costs and whether the materials could be sourced from the state or counties. The BVEM status report listed Colorado-based suppliers for concrete, rebar, project fuel, and equipment rentals. For the four-county region local share, the materials to mix concrete were excavated near the Rush Creek construction site. No information was found indicating that transformers were purchased in Colorado.

For the state-level labor costs, the BVEM status report indicated $67 \%$ of the Rush Creek Wind Farm craft workers are long-term Colorado residents (PSCo 2017a). For the state level, local labor content for foundation, erection, and electrical workers was averaged to $67 \%$. A higher percentage was applied to foundation workers because they would be easier to hire in state than erection workers, who are more specialized and likely to be part of a traveling construction crew. 
For the four-county region local share, researchers based the percentages on information obtained during an interview at the Limon Workforce Center.

For the development and other costs local shares, researchers relied primarily on the BVEM status report for the Rush Creek project and the transmission project. These reports were supplemented with discussion with NREL technical staff to utilize a justifiable local share percentage at the state level and four-county region. The land easement and site certificate/permitting expenditures are set at $100 \%$ because they should be directly spent in the counties surrounding Rush Creek.

\subsubsection{O\&M Costs and Local Share}

O\&M costs include labor, materials, and services at Rush Creek after construction is complete. Local share for O\&M is based on JEDI model defaults with input from technical experts. O\&M costs were modeled at the same inputs for the state level and four-county region. However, local share percentages differ at the state level or four-county region.

\section{O\&M Costs}

Average O\&M costs were reported in the 2016 Cost of Wind Energy Review. The total O\&M cost reported was $\$ 43.60 / \mathrm{kW}$ after subtracting land lease costs to account for the cost breakdown in the JEDI model. Researchers scaled labor costs based on interviews with knowledgeable stakeholders. The remaining costs were distributed across JEDI materials and services categories using model defaults. Table 16 provides the modeled O\&M costs for the state level and fourcounty region.

Table 16. JEDI O\&M Costs $(\$ 43.60 / \mathrm{kW})$ for Rush Creek at the State Level and Four-County Region

\begin{tabular}{|c|c|c|c|}
\hline Operation and Maintenance & Cost & $\begin{array}{l}\text { Cost per } \\
\text { kW }\end{array}$ & $\begin{array}{l}\% \text { of Total } \\
\text { Project Cost }\end{array}$ \\
\hline \multicolumn{4}{|l|}{ Labor } \\
\hline \multicolumn{4}{|l|}{ Personnel } \\
\hline Field salaries & $\$ 1,613,639$ & $\$ 2.69$ & $6.2 \%$ \\
\hline Administrative & $\$ 151,872$ & $\$ 0.25$ & $0.6 \%$ \\
\hline Management & $\$ 282,048$ & $\$ 0.47$ & $1.1 \%$ \\
\hline Labor/personnel subtotal & $\$ 2,047,559$ & $\$ 3.41$ & $7.8 \%$ \\
\hline \multicolumn{4}{|l|}{ Materials and Services } \\
\hline Vehicles & $\$ 674,431$ & $\$ 1.12$ & $2.6 \%$ \\
\hline Site maintenance/miscellaneous services & $\$ 263,028$ & $\$ 0.44$ & $1.0 \%$ \\
\hline Fees, permits, licenses & $\$ 131,514$ & $\$ 0.22$ & $0.5 \%$ \\
\hline Utilities & $\$ 526,056$ & $\$ 0.88$ & $2.0 \%$ \\
\hline Insurance & $\$ 5,058,229$ & $\$ 8.43$ & $19.3 \%$ \\
\hline Fuel (motor vehicle gasoline) & $\$ 263,028$ & $\$ 0.44$ & $1.0 \%$ \\
\hline Consumables/tools and miscellaneous supplies & $\$ 1,709,681$ & $\$ 2.85$ & $6.5 \%$ \\
\hline Replacement parts/equipment/spare parts inventory & $\$ 14,982,475$ & $\$ 24.97$ & $57.3 \%$ \\
\hline
\end{tabular}




\begin{tabular}{llll}
\hline Operation and Maintenance & Cost & $\begin{array}{l}\text { Cost per } \\
\text { kW }\end{array}$ & $\begin{array}{l}\text { \% of Total } \\
\text { Project Cost }\end{array}$ \\
\hline Materials and Services Subtotal & $\$ 23,608,441$ & $\$ 39.35$ & $90.2 \%$ \\
\hline Sales tax (materials and equipment purchases) & $\$ 503,631$ & $\$ 0.84$ & $1.9 \%$ \\
\hline Other taxes/payments & $\$ 0$ & $\$ 0.00$ & $0.0 \%$ \\
\hline Total O\&M Cost & $\$ \mathbf{2 6 , 1 5 9 , 6 3 1}$ & $\mathbf{\$ 4 3 . 6 0}$ & $\mathbf{1 0 0 . 0 \%}$ \\
\hline
\end{tabular}

\section{O\&M Local Share}

O\&M local share JEDI defaults were reviewed to determine if the inputs are representative of expected state-level and county-level expenditures for Rush Creek. After review, except for the replacement parts/equipment/spare parts inventory, analysts determined the JEDI defaults for local share percentages at the state level were reasonable assumptions.

Because Vestas turbines, manufactured in Colorado, were installed at Rush Creek, a reasonable assumption would be that Vestas provides some replacement parts and equipment. To create a justifiable local share percentage for the replacement parts category in the JEDI model inputs, researchers analyzed existing data on failure rates and repair costs on average across the wind industry. Failure rates for turbine equipment were summarized in Operations Expenditures: Historical Trends and Continuing Challenges (Lantz 2013). Gearbox, blades, and generator replacement costs, as well as the replacement crane and labor costs, were provided in propriety data reviewed by NREL researchers. Researchers calculated a local share percentage that assumes that the gearbox and generators would be sourced out of state but that Vestas would supply replacement blades. Local share assumptions for blade replacements are $66 \%$ of equipment expenditures, $80 \%$ of labor expenditures, and $100 \%$ of the crane expenditures, which would be spent in state. The local share is $44 \%$ based on failure rate, costs, and the expenditure spent in state for replacement parts.

At the county level, local share percentages include the amount of expenditures expected to be spent in the four-county region. For labor local share, researchers assumed that half of the O\&M workers employed for Rush Creek would live in the four-county region. Other local share percentages were calculated based on interviews with stakeholders and research in local communities. There is currently no manufacturing potential to provide replacement parts, equipment, or spare parts in the four-county region. Therefore, the county-level local share is $0 \%$ for both JEDI model runs.

O\&M local share percentages at the state level and four-county region are shown in Table 17. 
Table 17. O\&M Local Share Inputs for the Rush Creek JEDI Model

\begin{tabular}{|lll}
\hline Operation and Maintenance & $\begin{array}{l}\text { State-Level } \\
\text { Local Share }\end{array}$ & $\begin{array}{l}\text { Four-County Region } \\
\text { Local Share }\end{array}$ \\
\hline Labor & & \\
\hline \multicolumn{1}{|c|}{ Personnel } & & \\
\hline Field salaries & $100 \%$ & $50 \%$ \\
\hline Administrative & $100 \%$ & $50 \%$ \\
\hline Management & $100 \%$ & $50 \%$ \\
\hline Materials and Services & & \\
\hline Vehicles & & \\
\hline Site Maintenance/miscellaneous services & $100 \%$ & $10 \%$ \\
\hline Fees, permits, licenses & $80 \%$ & $80 \%$ \\
\hline Utilities & $100 \%$ & $100 \%$ \\
\hline Insurance & $100 \%$ & $10 \%$ \\
\hline Fuel (motor vehicle gasoline) & $0 \%$ & $0 \%$ \\
\hline Consumables/tools and miscellaneous supplies & $100 \%$ & $100 \%$ \\
\hline Replacement parts/equipment/spare parts inventory & $100 \%$ & $20 \%$ \\
\hline d & $44 \%$ & $0 \%$ \\
\hline Sales tax (materials and equipment purchases) & $100 \%$ & $100 \%$ \\
\hline Other taxes/payments & $100 \%$ & $100 \%$ \\
\hline
\end{tabular}

\subsubsection{Other Parameters}

Other parameters for JEDI inputs include financial parameters, land lease payments, and payroll parameters. The other parameter inputs are the same for each model scenario. Table 18 summarizes the data inputs and their source for the Other Parameters category. 
Table 18. Other Parameters for Rush Creek JEDI Inputs

\begin{tabular}{|c|c|c|c|}
\hline Financial Parameters & & Local Share & Source \\
\hline \multicolumn{4}{|l|}{ Debt Financing } \\
\hline Percentage financed & $44 \%$ & $0 \%$ & Xcel-PUC filing \\
\hline Years financed (term) & 10 & & Xcel-PUC filing \\
\hline Interest rate & $5 \%$ & & Xcel-PUC filing \\
\hline \multicolumn{4}{|l|}{ Equity Financing/Repayment } \\
\hline Percentage equity & $56 \%$ & & Xcel-PUC filing \\
\hline $\begin{array}{l}\text { Individual investors } \\
\text { (percent of total equity) }\end{array}$ & $0 \%$ & $0 \%$ & Xcel-PUC filing \\
\hline $\begin{array}{l}\text { Corporate investors } \\
\text { (percent of total equity) }\end{array}$ & $100 \%$ & $0 \%$ & Xcel-PUC filing \\
\hline Return on equity (annual interest rate) & $10 \%$ & & Xcel-PUC filing \\
\hline Repayment term (years) & 10 & & Xcel-PUC filing \\
\hline \multicolumn{4}{|l|}{ Tax Parameters } \\
\hline $\begin{array}{l}\text { Local property tax rate } \\
\text { (avg. millage rate }-\$ / \$ 1,000 \text { ) }\end{array}$ & $\$ 0.08$ & & CRS §39-4-101 \\
\hline $\begin{array}{l}\text { Assessed value } \\
\text { (percent of construction cost) }\end{array}$ & $24 \%$ & & CRS §39-4-101 \\
\hline Taxable value & $\$ 219,000,000$ & & CRS §39-4-101 \\
\hline Taxes per MW & NA & & \\
\hline Local taxes & $\$ 2,227,373$ & $100 \%$ & CRS §39-4-101 \\
\hline Local sales tax rate & $2.90 \%$ & $100 \%$ & CRS §39-4-101 \\
\hline \multicolumn{4}{|l|}{ Land Lease Parameters } \\
\hline Land lease cost (per turbine) & $\$ 6,000$ & & Stakeholder interview \\
\hline Number of turbines & 300 & & Stakeholder interview \\
\hline Land lease (total cost) & $\$ 1,800,000$ & & Stakeholder interview \\
\hline $\begin{array}{l}\text { Lease payment recipient } \\
(\mathrm{F}=\text { farmer/household, } \mathrm{O}=\text { other })\end{array}$ & $\mathrm{F}$ & $100 \%$ & Stakeholder interview \\
\hline
\end{tabular}

Financial parameters, including debt financing and equity financial inputs, were provided in Xcel-PUC fillings, specifically Hearing Exhibits 100 (Jackson 2016) and 110 (Blair 2016). The local share percentage for financial parameters is conservatively set to $0 \%$ because of the uncertainty regarding where Xcel holds the company's equity and debt.

Rush Creek Wind Farm is a qualified, state-assessed renewable energy project. Inputs for tax parameters are based on a property taxation law codified under Colorado Revised Statutes § 394-101 (House Bill 10-1431). The Tax Factor Template - Renewable in Service on or after Jan. 1, 2012, provided by the Colorado Department of Local Affairs was used to calculate the estimated 
annual property tax value in the local four-county region. ${ }^{52}$ The 2016 Colorado Capital Cost Thresholds were used because the money value year in the JEDI model is 2016 . Because $100 \%$ of the assessed value revenue should remain in state and the counties surrounding Rush Creek, the local share percentage is $100 \%$.

The land lease input is based on an interview with a participating landowner in the Rush Creek project, with $\$ 6,000$ per turbine selected as a conservative estimate. Land lease payments are also based on generation and may differ depending on the property owner. The local share of $100 \%$ indicates that the land lease payments are provided to property owners in the four-county region and assumes the property owner lives within the four-county region.

Payroll parameters are based on Bureau of Labor Statistics data for workers in the foundation, erection, electrical, and management labor categories. Table 19 lists the modeled payroll parameters.

Table 19. Rush Creek Payroll Parameters for Construction and O\&M Labor

\begin{tabular}{lll}
\hline & Wage per Hour & Employer Payroll Overhead \\
\hline Construction Labor & & \\
Foundation & $\$ 20.33$ & $37.6 \%$ \\
Erection & $\$ 28.01$ & $37.6 \%$ \\
\hline Electrical & $\$ 27.57$ & $37.6 \%$ \\
Management/supervision & $\$ 46.59$ & $37.6 \%$ \\
\hline O\&M Labor & & \\
\hline Foundation & $\$ 29.54$ & $37.6 \%$ \\
\hline Erection & $\$ 17.18$ & $37.6 \%$ \\
\hline Electrical & $\$ 63.09$ & $37.6 \%$ \\
\hline
\end{tabular}

Researchers verified the wage per hour reported by the Bureau of Labor Statistics with NREL technical experts to ensure wages were representative of pay in the wind industry. Employee payroll overhead of $37.6 \%$ is a JEDI default based on previous economic modeling.

\subsection{Qualitative Data}

Researchers also conducted qualitative interviews to gain a richer picture of wind energy's economic impacts to the state and rural America. Qualitative interviews were conducted with stakeholders in the four-county region and focused on exploring the economic impacts to rural communities outside of Rush Creek. Interviews were also conducted with Vestas and Coloradobased subcomponent suppliers to examine turbine and supply chain economic impacts from instate manufacturing of wind turbines.

\footnotetext{
${ }^{52}$ The spreadsheet template can be accessed at https://www.colorado.gov/pacific/dola/renewable-energy.
} 


\subsubsection{Structured Interviews}

Induced impacts are rarely validated because of the time intensiveness and difficulty of the task, despite being a common economic impact metric. Induced impacts include restaurant, lodging, grocery store, and retail workers. Qualitative research was used to verify if rural communities near Rush Creek experience induced impacts that were predicted by the JEDI model.

To explore potential impacts, researchers conducted structured interviews with business representatives in Lincoln County. The county was selected because it contains the city of Limon, which hosts the majority of businesses in close proximity to Rush Creek. Researchers contacted 62 businesses (every business in Lincoln County with a valid address) and interviewed 18. Interviews were conducted with owners/managers of hardware stores, grocery stores, hotels and motels, RV parks, liquor stores, restaurants, and retailers. Business representatives were asked a predetermined list of 15 questions related to jobs and economic impacts they may have encountered during Rush Creek's construction phase. Questions included whether businesses had experienced economic growth, hired new employees, or required employees to work longer hours in the past year. Representatives from businesses were read a list of seven possible reasons for the increase and asked to select two. Rush Creek construction was listed as a reason, along with tourism, regional growth and development, internal operations, and seasonal agricultural workers. Researchers also asked several questions related to perceptions of wind energy, including how interviewees feel about wind development in their community and if Rush Creek has been beneficial to their business. For a full list of interview questions, see Appendix F. At the end of the interview, respondents were given the opportunity to provide additional comments or address concerns.

\subsubsection{Semistructured Interviews}

Researchers also conducted 21 semistructured interviews with individuals in towns surrounding Rush Creek. The interviews also focused on exploring wind energy's effect on rural communities and potential economic impacts from Rush Creek, and were conducted in a more conversational style, following the natural flow of discussion when they strayed in relevant but different directions. This approach often led to unanticipated insights or new themes.

Semistructured interviews ranged from 30 minutes to 2 hours in length. Interviewees included local business owners and managers but the list was expanded to include an Elbert County commissioner, the Limon Workforce Center, the LCEDC, a Lincoln County land use administrator, a landowner, wind farm O\&M workers, and wind farm construction workers. Semistructured interviews were conducted to learn about county-level induced impacts, perceptions of wind development, county tax revenues and how they are used, Rush Creekrelated employment, and local share of equipment and workforce. They also provided information about Rush Creek's development and construction process from individuals who were directly involved.

\subsubsection{Vestas and Supply Chain}

Researchers also explored local revenue, turbine, and supply chain impacts to the state through interviews with representatives from Vestas and turbine subcomponent manufacturers in Colorado. Researchers toured the Vestas tower facility in Pueblo, the nacelle facility in Brighton, and the blade facility in Brighton. Several Colorado-based suppliers to Vestas provided useful 
insights, such as Hexcel, a composite manufacturer, and Aluwind, a manufacturer of aluminum tower internals. Tours with Vestas and subcomponent manufacturers were conducted to collect data on employment, including types of jobs available in wind manufacturing and the number of people Vestas and subcomponent manufacturing plants employ in the state. Tours were conducted to learn more about the equipment manufacturing process, such as the man hours necessary to complete parts, from what countries/states internal components are sourced, how turbines are transported to construction sites, and what skills and training are necessary for factory jobs. Researchers wanted to learn why Vestas and subcomponent manufacturers set up their North America operations in Colorado. Tours provided information about the future direction of the wind manufacturing industry and wind manufacturing's role in the state economy. 


\section{Conclusion}

\subsection{Summary of Results}

This economic analysis of the Rush Creek Wind Farm 1) quantitatively modeled the gross economic impacts from the 600-MW wind project and 2) engaged with community members to draw specific insight on how wind development impacts their local economy.

Based on the analysis, Rush Creek construction supports jobs and economic development throughout numerous sectors of Colorado's economy. JEDI analysis estimates that Rush Creek supported 2,970 FTEs and \$280 million of in-state GDP during the construction period.

Because wind turbines were manufactured by Vestas in Colorado, the state experienced greater economic impacts than if manufacturing had occurred out of state. Based on the model results, Vestas turbine manufacturing and the wind-related supply chain supported 830 jobs and $\$ 90$ million in GDP of the total construction-phase economic impacts. The large share of in-state economic impacts associated with wind turbine manufacturing highlights the potential value of domestic manufacturing.

The state's economy will also be impacted during the O\&M phase. Based on model results, Rush Creek Wind Farm will support 180 long-term jobs and \$20 million in GDP in Colorado annually, during the 25-year project life.

JEDI model results from the wind plant construction phase align with data reported by Xcel Energy and interviewee-reported data during wind plant construction. Our model results indicate 290 full-time equivalent on-site construction workers were supported during Rush Creek construction. During a wind farm's construction phase, specialized construction crews generally work 4 to 6 months during the 18-month construction period. According to stakeholder interviews, about 200 to 300 people work construction on the project at one time. Updates from Xcel Energy confirm that at one point, 320 people were working construction on the project (Xcel Energy 2018a).

Researchers analyzed impacts to the state's economy and performed a separate analysis on the four-county region where Rush Creek turbines are sited. At the four county-region level, model results and interviews demonstrate that the rural community's economy is impacted by the 600MW wind development. Within Rush Creek's four-county region (Cheyenne, Elbert, Lincoln, and Kit Carson counties), the JEDI model estimates that the Rush Creek construction phase supported 620 local (in-region) jobs and an estimated \$36 million in local GDP. During the O\&M phase, Rush Creek is estimated to support 47 long-term jobs annually (12 on-site O\&M jobs in the four-county region) and support approximately $\$ 6$ million in local GDP during the 25-year O\&M phase of the facility. According to local interviews, Rush Creek is expected to support 15 to 18 FTE permanent on-site O\&M jobs in the four-county region, which is close to the 12 FTE regional on-site jobs that the JEDI model predicted. Supporting a predictable source of jobs is welcome in this rural economy, even in small numbers. Lincoln County's total employment is 2,254 workers (BLS 2017). 
Interviews with community members shed light on the economic impacts from wind development that rural communities experience. During the interviews, $72 \%$ of business representatives responded that the Rush Creek Wind Farm was beneficial to their business. No respondent interviewed was opposed to wind development in his or her community. In several metrics, including hiring practices, employee workloads, and business revenue, representatives indicated Rush Creek was the primary reason for the increase in their business. Case studies with community leaders, presented throughout this report, also highlight the economic development opportunities from wind energy - including financial opportunities for landowners, potential long-term jobs, new business opportunities such as RV parks, and additional revenue for county governments. However, local communities also face challenges from wind energy development, including a shortage of local housing, a shortage of lodging for temporary workers, and difficulty finding a sufficient locally qualified workforce. To mitigate these challenges, communities can work to maximize the local impact of wind project development prior to construction. Further research and community engagement prior to wind development could provide additional perspectives.

\subsection{Maximizing Economic Development from Wind Energy}

There are many lessons learned and potential areas for enhanced economic development identified during the Rush Creek Wind Farm analysis that may be applicable to other communities. Although each state and local community has a unique economy, there are general opportunities that apply to communities seeking to maximize economic impacts from nearby wind developments. Opportunities to maximize economic development from wind energy include the following action items:

- Evaluate wind development revenue. Counties can review their existing policies to ensure they receive the revenue streams that are typically provided by wind developers to construct a wind plant in their community, such as sales-and-use taxes and building permitting fees. Eastern Colorado counties are using revenues from wind development for revitalization projects and infrastructure upgrades. Counties are also saving revenues from wind development for times of economic downturn, ensuring the long-term sustainability of rural communities. Counties can provide support to residents by engaging with wind developers and asking questions about land lease payments, good neighbor payments, and other revenuegenerating opportunities.

- Plan for housing needs. Cities and counties can coordinate with wind developers during the initial planning process to meet housing and lodging needs for construction crews. Often rural communities do not have a housing supply to accommodate sizeable working crews that accompany wind plant construction. This lack of supply can lead to the housing shortages and increased housing prices as seen in the four-county region near Rush Creek. By planning and constructing additional RV parks, hotels, or other lodging, developers would feel less strain in finding appropriate lodging, communities could see an increase in spending in the local community with more workers living nearby, and cities could utilize the additional housing stock for O\&M workers or other affordable housing after wind plant construction is complete.

- Engage with local businesses. Organizations can prepare a database of potential local businesses that support wind farm construction, including but not limited to water haulers, 
concrete trucks, and crane operators. Wind developers and local governments could prepare ahead to ensure these businesses have an adequate skillset and workforce to support wind construction. A good example of this is the partnership between the Limon Workforce Center and Rush Creek to fill the workforce needs (see Case Study: Rush Creek Partnership).

- Provide services for the workforce. Local communities can identify likely worker services (e.g., food, recreation, housing, services) needed during the construction phase. Community leaders could work with local businesses to prepare for and take advantage of the construction phase to expand local services and maximize local economic impact. This would also provide openings for local businesses to plan for increased demands, such as needing to hire additional employees.

- Support wind manufacturing and supply chain. At the state level, domestic wind turbine manufacturing and supply chains have the greatest potential to support economic development opportunities. Although wind manufacturing potential varies between states, there is an opportunity to expand the domestic wind-related supply chain. Expanding the wind supply chain was demonstrated to be an opportunity to support jobs and spur economic activity in communities.

- Support the local workforce. Local communities and states can work with wind developers and educational institutions to provide training and job programs to support new workforce needs using local labor. Local workers can gain new skills while wind developers mitigate concerns around finding a qualified workforce.

- Develop an O\&M workforce. To further maximize economic opportunities from the O\&M phase, workers could be incentivized to live near the wind development, for example by offering reduced housing rates to live in the area. Additionally, training programs could be offered for wind-related careers, such as a wind technician. Ensuring O\&M workers live in communities near the wind plants can help reverse rural communities' shrinking population trend as well as increase impacts from workers spending money in the rural community.

JEDI model results and interviews demonstrate that state and local economies are impacted by wind development. However, by enabling states and communities, they can maximize the economic development opportunities during wind construction and operating years.

To better understand how stakeholders can capture additional economic development, further research is encouraged, as follows:

- Engaging with communities to research a wind plant during operating years to validate whether modeled impacts are realized

- Assessing the impacts of wind developments over time to understand how economies change as wind construction crews leave and the long-term O\&M phase begins

- Quantifying the indirect and induced impacts from the wind energy supply chain on state and local businesses and tax bases

- Developing a guidebook for county-level stakeholders to ensure they are maximizing economic development from wind energy. 


\section{References}

AWEA. 2017. U.S. Wind Industry Annual Market Report, Year Ending 2017. https://www.awea.org/2017-market-reports.

American Wind Energy Association (AWEA). 2019. U.S. Wind Energy State Facts: Wind Energy in Colorado. https:/www.awea.org/Awea/media/Resources/StateFactSheets/ Colorado.pdf.

Bureau of Economic Analysis. 2006. "Frequently Asked Questions." (Quarterly Census of Employment and Wages). https://www.bea.gov/faq/index.cfm?faq id=183.

Blair, D. 2016. Direct Testimony and Attachments of Deborah A. Blair. Proceeding No. 16A0117E. Public Service Company of Colorado. https://www.xcelenergy.com/staticfiles/xeresponsive/Company/Rates\%20\&\%20Regulations/CO-Rush-Creek-Direct-Testimony-ofDeborah-Blair.pdf.

Bureau of Labor Statistics. 2017. "County and Employment Wages in Colorado-Fourth Quarter 2017.” U.S. Department of Labor, Washington, D.C. https://www.bls.gov/regions/mountainplains/news-release/countyemploymentandwages colorado.htm.

Department of Local Affairs. 2017. Forty-Seventh Annual Report. Division of Property Taxation, State of Colorado. https://www.colorado.gov/pacific/dola/annual-reports.

Dillman, D., J. Smyth, L. Christian. 2009. Internet, Mail, and Mixed-Mode Surveys. John Wiley \& Sons, Inc., New Jersey.

Database of State Incentives for Renewables \& Efficiency. 2015. Renewable Energy Standard. DSIRE USA. Accessed January 21, 2017. http://programs.dsireusa.org/system/program/detail/133.

Energy Futures Initiative (EFI) and National Association of State Energy Officials (NASEO). 2018. Energy Employment by State. https://www.usenergyjobs.org/report.

Energy Information Administration (EIA). 2018a. "Electric Power Monthly." https://www.eia.gov/electricity/monthly/.

EIA. 2018b. "Colorado Electricity Profile 2017.” Accessed February 2019. https://www.eia.gov/electricity/state/Colorado/.

Environmental Entrepreneurs (E2). (2018). Clean Jobs Colorado. https://www.e2.org/wpcontent/uploads/2018/06/Clean-Jobs-Colorado-2018.pdf.

Global Wind Network. 2014. U.S. Wind Energy Manufacturing and Supply Chain: A Competitiveness Analysis. U.S. Department of Energy.

https://www.energy.gov/eere/downloads/us-wind-energy-manufacturing-supply-chaincompetitiveness-analysis. 
Hill, R. 2016. Direct Testimony and Attachments of Riley Hill. Proceeding No. 16A-0117E. Public Service Company of Colorado. https://www.xcelenergy.com/staticfiles/xeresponsive/Company/Rates\%20\&\%20Regulations/CO-Rush-Creek-Direct-Testimony-of-RileyHill.pdf.

House Bill 10-1431. 2010. Renewable Energy Facility Property Tax Valuation in Colorado. Accessed July 2018. https://legiscan.com/CO/rollcall/HB1431/id/106844.

Jackson, A. Direct Testimony and Attachments of Alice K. Jackson. 2016. Proceeding No. 16A0117E. Public Service Company of Colorado. https://www.xcelenergy.com/staticfiles/xeresponsive/Company/Rates\%20\&\%20Regulations/CO-Rush-Creek-Direct-Testimony-of-AliceJackson.pdf.

Lazard. 2018. Lazard's Levelized Cost of Energy Analysis - Version 12.0. https://www.lazard.com/media/450784/lazards-levelized-cost-of-energy-version-120-vfinal.pdf.

Lantz, E. 2013. "Operations Expenditures: Historical Trends and Continuing Challenges." NREL/PR-6A20-58606. National Renewable Energy Laboratory (NREL). Golden, CO. https://www.nrel.gov/docs/fy13osti/58606.pdf.

Lantz, E., and S. Tegen. 2008. Variables Affecting Economic Development of Wind Energy. NREL/CP-500-43506. National Renewable Energy Laboratory (NREL). Golden, CO. Presented at WINDPOWER 2008, Houston, Texas, June 1-4, 2008.

https://www.nrel.gov/docs/fy08osti/43506.pdf.

Metro Denver Economic Development Corporation. 2017. "Metro Denver is Leading the Way to a Balanced Energy Economy.” http://www.metrodenver.org/industries/energy/.

Office of Energy Efficiency and Renewable Energy. 2009. Economic Development Impacts in Colorado from Four Vestas Manufacturing Facilities. DOE/GO-102009-2717. U.S. Department of Energy. https://www.nrel.gov/docs/fy09osti/44620.pdf.

Public Service Company of Colorado (PSCo). Public Service Company of Colorado's Best Value Employment Metrics Status Report Regarding the Generation Portion of the Rush Creek Wind Project. 2017a. Proceeding No. 16A-0117E, Proceeding No. 16V-0314E. https://www.dora.state.co.us/pls/efi/efi_p2_v2_demo.show document?p_dms document id=867 $164 \& p$ session $\mathrm{id}=$.

PSCo. 2017b. 2016 Electric Resource Plan; 2017 All Source Solicitation 30-Day Report. Proceeding No. 16A-0396E. Accessed July 2018. https://assets.documentcloud.org/documents/4340162/Xcel-Solicitation-Report.pdf.

PSCo. (2017c). 2016 Renewable Energy Standard Compliance Report. Proceeding No. 13A0836E. https://www.xcelenergy.com/staticfiles/xeresponsive/Company/Rates\%20\&\%20Regulations/Regulatory\%20Filings/CO-RES-ComplianceReport-2016\%20.pdf. 
Slattery, M., E. Lantz, B. Johnson. 2011. "State and local economic impacts from wind energy projects: Texas case study." Energy Policy 39, 7932.

https://www.sciencedirect.com/science/article/pii/S030142151100736.

Stehly, T., D. Heimiller, G. Scott. 2017. 2016 Cost of Wind Energy Review (Technical Report). NREL/TP-6A20-70363. National Renewable Energy Laboratory (NREL), Golden, CO (US). https://www.nrel.gov/docs/fy18osti/70363.pdf

Tegen, S., D. Keyser, F. Flores-Espino, R. Hauser. 2014. Economic Impacts from Indiana's First 1,000 Megawatts of Wind Power (Technical Report). NREL/TP-5000-60914. National

Renewable Energy Laboratory (NREL), Golden, CO (US).

https://www.nrel.gov/docs/fy14osti/60914.pdf.

U.S. Census Bureau. 2017. Genoa town, Colorado. American Factfinder.

https://factfinder.census.gov/faces/nav/jsf/pages/community facts.xhtml?src=bkmk.

Wiser, R., and M. Bolinger. 2017. 2016 Wind Technologies Market Report. Office of Energy Efficiency and Renewable Energy. U.S. Department of Energy.

https://www.energy.gov/sites/prod/files/2017/10/f37/2016_Wind_Technologies_Market_Report $\underline{101317 . p d f}$.

Wiser, R., and M. Bolinger. 2018. 2017 Wind Technologies Market Report. Office of Energy Efficiency and Renewable Energy. U.S. Department of Energy.

https://emp.lbl.gov/sites/default/files/2017_wind_technologies_market_report.pdf.

Xcel Energy. 2017a. Rush Creek Wind Project. Accessed June 5, 2017.

https://www.xcelenergy.com/energy portfolio/renewable_energy/wind/

rush creek wind project.

Xcel Energy. 2017b. Rush Creek Wind and Transmission Project.

https://www.transmission.xcelenergy.com/staticfiles/microsites/Transmission/Files/PDF/Projects /CO/Rush\%20Creek/CO-Rush-Creek-Wind-and-Transmission-Project-Fact-Sheet.pdf.

Xcel Energy. 2018a. Rush Creek Wind and Transmission Project.

https://www.transmission.xcelenergy.com/staticfiles/microsites/Transmission/Files/PDF/Rush-

Creek-Transmission-Mailer-February.pdf.

Xcel Energy. 2018b. "Xcel Energy aims for zero-carbon electricity by 2050."

https://www.xcelenergy.com/company/media_room/news_releases/xcel_energy_aims_for_zerocarbon_electricity_by_2050.

Zawacki, P. 2016. Direct Testimony and Attachments of William P. Zawacki. Proceeding No. 16A-0117E. Public Service Company of Colorado. https://www.xcelenergy.com/staticfiles/xeresponsive/Company/Rates\%20\&\%20Regulations/CO-Rush-Creek-Direct-Testimony-of-

William-Zawacki.pdf. 


\section{Appendix A. Colorado Wind Resources}

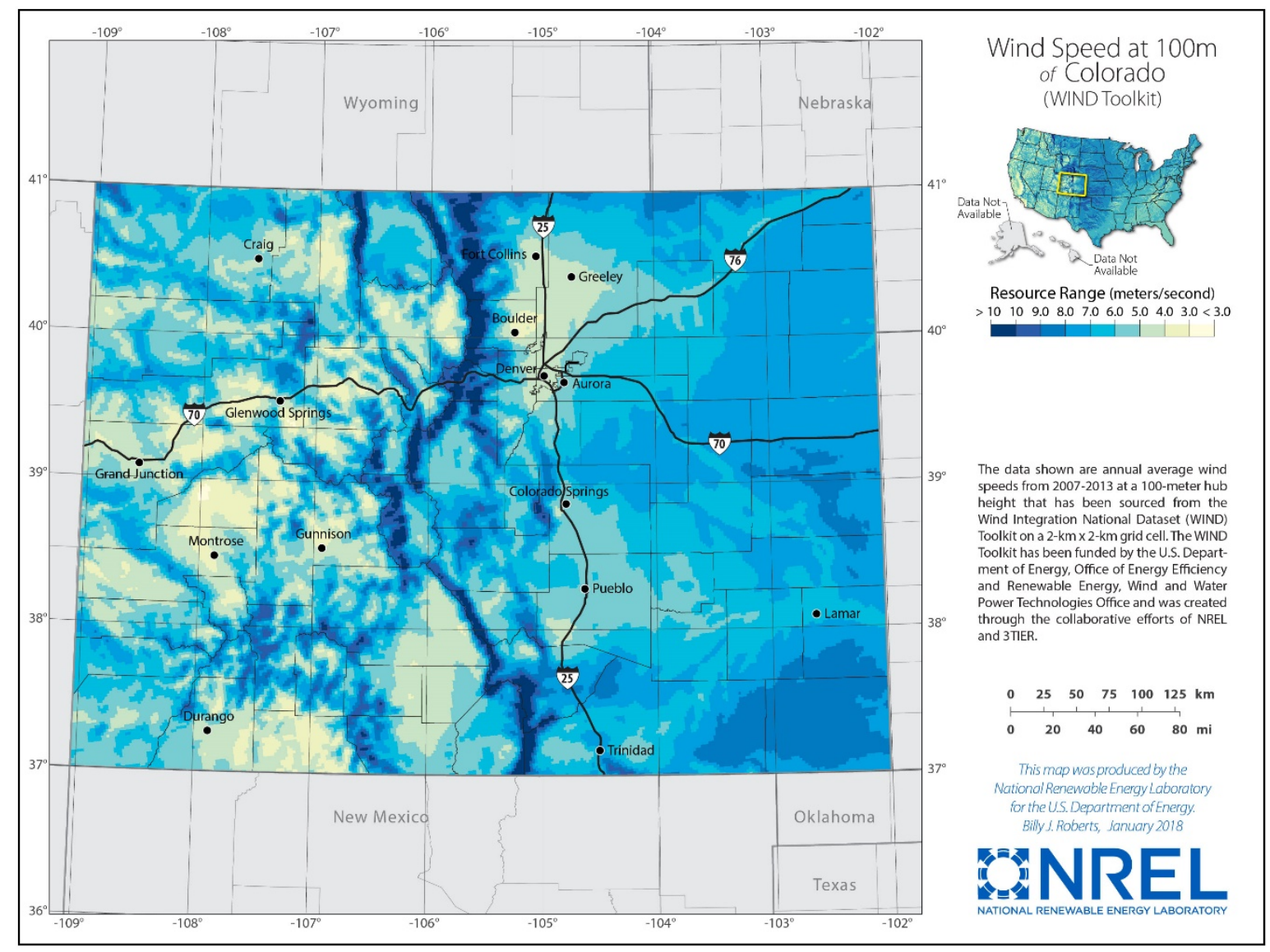

Figure A-1. Colorado 100-meter wind resource map 


\section{Appendix B. Xcel-Reported Installed Project Costs and Operation and Maintenance Scenario}

Xcel reported to the Public Utility Commission (PUC) a total cost of the Rush Creek Wind farm of $\$ 915$ million or an installed project cost of $\$ 1,525 / \mathrm{kilowatt}(\mathrm{kW})$. Expected operation and maintenance $(\mathrm{O} \& \mathrm{M})$ costs are $\$ 46.30 / \mathrm{kW}$, which were calculated from Xcel data provided to the PUC (Zawacki 2016). Tables B-1 and B-2 list the Jobs and Economic Development Impact (JEDI) model inputs for the higher-cost scenario.

Table B-1. \$1,525/kW Balance-of-Plant JEDI Cost Inputs Using Xcel-Reported Data

\begin{tabular}{|c|c|c|c|c|}
\hline Balance of Plant & Cost & $\begin{array}{l}\text { Cost per } \\
\text { kW }\end{array}$ & $\begin{array}{l}\% \text { of Total } \\
\text { Project Cost }\end{array}$ & Source \\
\hline \multicolumn{5}{|l|}{ Materials } \\
\hline $\begin{array}{l}\text { Construction (concrete, rebar, } \\
\text { equipment, roads, and site } \\
\text { preparation) }\end{array}$ & $\$ 136,328,340$ & $\$ 227$ & $14.9 \%$ & JEDI model \\
\hline Transformer & $\$ 15,000,000$ & $\$ 25$ & $1.6 \%$ & Xcel-PUC filing \\
\hline Electrical (drop cable, wire) & $\$ 15,927,469$ & $\$ 27$ & $1.7 \%$ & JEDI model \\
\hline $\begin{array}{l}\text { High-voltage (HV) line } \\
\text { extension }\end{array}$ & $\$ 0$ & $\$ 0$ & $0.0 \%$ & Xcel-PUC filing \\
\hline Materials Subtotal & $\$ 167,255,809$ & $\$ 279$ & $18.3 \%$ & \\
\hline \multicolumn{5}{|l|}{ Labor } \\
\hline Foundation & $\$ 7,288,842$ & $\$ 12$ & $0.8 \%$ & JEDI model \\
\hline Erection & $\$ 8,368,670$ & $\$ 14$ & $0.9 \%$ & JEDI model \\
\hline Electrical & $\$ 13,497,855$ & $\$ 22$ & $1.5 \%$ & JEDI model \\
\hline Management/supervision & $\$ 5,399,142$ & $\$ 9$ & $0.6 \%$ & JEDI model \\
\hline Misc. & $\$ 48,592,279$ & $\$ 81$ & $5.3 \%$ & JEDI model \\
\hline Labor Subtotal & $\$ 83,146,789$ & $\$ 139$ & $9.1 \%$ & \\
\hline \multicolumn{5}{|l|}{ Development/Other Costs } \\
\hline \multicolumn{5}{|l|}{ HV sub/interconnection } \\
\hline Materials & $\$ 9,448,499$ & $\$ 16$ & $1.0 \%$ & JEDI model \\
\hline Labor & $\$ 2,699,571$ & $\$ 4$ & $0.3 \%$ & JEDI model \\
\hline Engineering & $\$ 8,702,300$ & $\$ 15$ & $1.0 \%$ & WISDEM \\
\hline Legal services & $\$ 7,018,885$ & $\$ 12$ & $0.8 \%$ & JEDI model \\
\hline Land easements & $\$ 4,275,000$ & $\$ 7$ & $0.5 \%$ & Stakeholder interview \\
\hline Site certificate/permitting & $\$ 4,000,000$ & $\$ 7$ & $0.4 \%$ & Xcel-PUC filing \\
\hline Development/Other Subtotal & $\$ 36,144,255$ & $\$ 60$ & $3.9 \%$ & \\
\hline Balance-of-Plant Total & $\$ 286,546,853$ & $\$ 478$ & $31.3 \%$ & \\
\hline Sales tax & $\$ 7,255,641$ & $\$ 12$ & $0.8 \%$ & \\
\hline
\end{tabular}


Table B-2. \$43.60/kW O\&M JEDI Cost Inputs Using Xcel-Reported Data

\begin{tabular}{|c|c|c|c|}
\hline Operation and Maintenance & Cost & $\begin{array}{l}\text { Cost per } \\
\text { kW }\end{array}$ & $\begin{array}{l}\% \text { of Total } \\
\text { Project Cost }\end{array}$ \\
\hline \multicolumn{4}{|l|}{ Labor } \\
\hline \multicolumn{4}{|l|}{ Personnel } \\
\hline Field salaries & $\$ 1,884,839$ & $\$ 3.14$ & $6.8 \%$ \\
\hline Administrative & $\$ 177,907$ & $\$ 0.30$ & $0.6 \%$ \\
\hline Management & $\$ 336,288$ & $\$ 0.56$ & $1.2 \%$ \\
\hline Labor/Personnel Subtotal & $\$ 2,399,034$ & $\$ 4.00$ & $8.6 \%$ \\
\hline \multicolumn{4}{|l|}{ Materials and Services } \\
\hline Vehicles & $\$ 709,983$ & $\$ 1.18$ & $2.6 \%$ \\
\hline Site maintenance/miscellaneous services & $\$ 276,893$ & $\$ 0.46$ & $1.0 \%$ \\
\hline Fees, permits, licenses & $\$ 138,447$ & $\$ 0.23$ & $0.5 \%$ \\
\hline Utilities & $\$ 553,787$ & $\$ 0.92$ & $2.0 \%$ \\
\hline Insurance & $\$ 5,324,875$ & $\$ 8.87$ & $19.2 \%$ \\
\hline Fuel (motor vehicle gasoline) & $\$ 276,893$ & $\$ 0.46$ & $1.0 \%$ \\
\hline Consumables/tools and miscellaneous supplies & $\$ 1,799,808$ & $\$ 3.00$ & $6.5 \%$ \\
\hline Replacement parts/equipment/spare parts inventory & $\$ 15,772,280$ & $\$ 26.29$ & $56.8 \%$ \\
\hline Materials and Services Subtotal & $\$ 24,852,966$ & $\$ 41.42$ & $89.5 \%$ \\
\hline Sales tax (materials and equipment purchases) & $\$ 530,180$ & $\$ 0.88$ & $1.9 \%$ \\
\hline Other taxes/payments & $\$ 0$ & $\$ 0.00$ & $0.0 \%$ \\
\hline Total O\&M Cost & $\$ 27,782,180$ & $\$ 46.30$ & $100.0 \%$ \\
\hline
\end{tabular}




\section{Appendix C. State-Level JEDI Model Results: Rush Creek Wind Farm Xcel Energy-Reported Costs}

Table C-1 summarizes the statewide economic impacts based on the Xcel-reported installed project and O\&M costs analyzed using the JEDI model.

Table C-1. State-Level Rush Creek JEDI Model Results: Xcel Energy-Reported Costs

\begin{tabular}{lllll}
\hline & $\begin{array}{l}\text { Jobs } \\
\text { (Full-Time } \\
\text { Equivalents } \\
\text { [FTEs]) }\end{array}$ & $\begin{array}{l}\text { Earnings } \\
\mathbf{( \$ \text { million) }}\end{array}$ & $\begin{array}{l}\text { Output } \\
\text { (\$ million) }\end{array}$ & $\begin{array}{l}\text { Gross } \\
\text { Domestic } \\
\text { Product } \\
\text { (GDP) } \\
\text { (\$ million) }\end{array}$ \\
\hline $\begin{array}{l}\text { During Construction Period } \\
\text { Construction and interconnection labor }\end{array}$ & 314 & $\$ 25.1$ & & \\
\hline $\begin{array}{l}\text { Construction-related services } \\
\text { Total project development and on-site labor }\end{array}$ & 64 & $\$ 5.6$ & & \\
impacts & 378 & $\$ 30.7$ & $\$ 35.6$ & $\$ 31.5$ \\
\hline $\begin{array}{l}\text { Local revenue, turbine, and supply chain } \\
\text { impacts }\end{array}$ & 2,613 & $\$ 164.4$ & $\$ 564.2$ & $\$ 244.0$ \\
\hline $\begin{array}{l}\text { Induced impacts } \\
\text { Total Impacts }\end{array}$ & 1,166 & $\$ 59.7$ & $\$ 178.8$ & $\$ 104.8$ \\
\hline $\begin{array}{l}\text { During Operating Years (Annual) } \\
\text { On-site labor impacts }\end{array}$ & $\mathbf{4 , 1 5 6}$ & $\$ 254.7$ & $\$ 778.6$ & $\$ 380.3$ \\
\hline $\begin{array}{l}\text { Local revenue, turbine, and supply chain } \\
\text { impacts }\end{array}$ & 102 & & & \\
\hline $\begin{array}{l}\text { Induced impacts } \\
\text { Total Impacts }\end{array}$ & 58 & $\$ 6.6$ & $\$ 23.3$ & $\$ 13.8$ \\
\hline
\end{tabular}

Notes: Earnings and output values are millions of dollars in year 2016 dollars. Construction and operation jobs are full-time equivalent for a period of 1 year (1 FTE = 2,080 hours). Wind farm workers include field technicians, administration, and management. Economic impacts "During Operating Years" represent impacts that occur from wind farm operations/expenditures. The analysis does not include impacts associated with spending of wind farm "profits" and assumes no tax abatement unless noted. 


\section{Appendix D. Four-County Region JEDI Model Results: Rush Creek Wind Farm Xcel Energy-Reported Costs}

Table D-1 summarizes the four-county region economic impacts based on the Xcel-reported installed project and O\&M costs analyzed using the JEDI model.

Table D-1. Four-County Level Rush Creek JEDI Model Results: Xcel Energy-Reported Costs

\begin{tabular}{|c|c|c|c|c|}
\hline & $\begin{array}{l}\text { Jobs } \\
\text { (FTEs) }\end{array}$ & $\begin{array}{l}\text { Earnings } \\
\text { (\$ million) }\end{array}$ & $\begin{array}{l}\text { Output } \\
\text { (\$ million) }\end{array}$ & $\begin{array}{l}\text { GDP } \\
\text { (\$ million) }\end{array}$ \\
\hline \multicolumn{5}{|l|}{ During Construction Period } \\
\hline Construction and interconnection labor & 17 & $\$ 1.2$ & & \\
\hline Construction-related services & 1 & $\$ 0.0$ & & \\
\hline $\begin{array}{l}\text { Total project development and on-site labor } \\
\text { impacts }\end{array}$ & 18 & $\$ 1.2$ & $\$ 1.3$ & $\$ 1.2$ \\
\hline Local revenue and supply chain impacts & 858 & $\$ 33.2$ & $\$ 107.3$ & $\$ 48.1$ \\
\hline Induced impacts & 94 & $\$ 2.6$ & $\$ 13.2$ & $\$ 7.1$ \\
\hline Total Impacts & 970 & $\$ 37.0$ & $\$ 121.8$ & $\$ 56.4$ \\
\hline \multicolumn{5}{|l|}{ During Operating Years (Annual) } \\
\hline On-site labor impacts & 13 & $\$ 1.0$ & $\$ 1.0$ & $\$ 1.0$ \\
\hline Local revenue and supply chain impacts & 29 & $\$ 0.9$ & $\$ 7.1$ & $\$ 4.5$ \\
\hline Induced impacts & 7 & $\$ 0.2$ & $\$ 1.1$ & $\$ 0.6$ \\
\hline Total Impacts & 49 & $\$ 2.1$ & $\$ 9.2$ & $\$ 6.1$ \\
\hline
\end{tabular}

Notes: Earnings and output values are millions of dollars in year 2016 dollars. Construction and operation jobs are full-time equivalent for a period of 1 year ( $1 \mathrm{FTE}=2,080$ hours). Wind farm workers include field technicians, administration, and management. Economic impacts "During Operating Years" represent impacts that occur from wind farm operations/expenditures. The analysis does not include impacts associated with spending of wind farm "profits" and assumes no tax abatement unless noted. 


\section{Appendix E. Local Share Calculations for Colorado Turbine Costs}

Local share percentages were calculated for turbines (excluding blades and towers), blades, and towers. These percentages indicate the percentage of equipment cost expenditures that remained in Colorado. Cost breakdowns for towers and blades were obtained from the report U.S. Wind Energy Manufacturing and Supply Chain: A Competitiveness Analysis (GLWN 2014).

Appendices E.1-E.3 show graphs sourced from this report and the local share calculations conducted based on the cost breakdowns. Calculations are weighted averages that include the percentage of the blade, tower, or nacelle cost and the percentage that could be sourced from Colorado.

\section{Appendix E1. Blade Local Share Calculations}

Table E-1. Percentage of Material Expenditures Spent in Colorado

\begin{tabular}{llll}
\hline Blade Material & Percent of Cost & Percent from Colorado & Weighted Average \\
\hline Auxiliary materials & $0.35 \%$ & $50.00 \%$ & 0.17 \\
\hline Lightening protection system & $0.34 \%$ & $0.00 \%$ & 0.00 \\
\hline T-bolt & $0.34 \%$ & $0.00 \%$ & 0.00 \\
\hline Adhesive part B & $1.01 \%$ & $0.00 \%$ & 0.00 \\
\hline Adhesive part A & $1.01 \%$ & $0.00 \%$ & 0.00 \\
\hline Resin XP3416 & $5.25 \%$ & $0.00 \%$ & 0.00 \\
\hline Resin LY1564 & $16.10 \%$ & $0.00 \%$ & 0.00 \\
\hline Foam 50 mm & $9.57 \%$ & $0.00 \%$ & 0.00 \\
\hline Foam 40 mm & $10.38 \%$ & $0.00 \%$ & 0.00 \\
\hline Foam 20 mm & $2.27 \%$ & $0.00 \%$ & 0.00 \\
\hline Gelcoat & $2.23 \%$ & $0.00 \%$ & 0.00 \\
\hline Fiberglass mat +/- 45 & $1.97 \%$ & $100.00 \%$ & 1.97 \\
\hline Carbon mat - Unidir. & $31.59 \%$ & $100.00 \%$ & 31.59 \\
\hline Fiberglass mat & $17.58 \%$ & $100.00 \%$ & 17.58 \\
\hline
\end{tabular}

The percentage of blade material expenditures in Colorado (51.31\%) is included in the materials cost category in Table E-2 to calculate the percentage of total blade expenditures in Colorado. 
Table E-2. Percentage of Total Blade Expenditures Spent in Colorado

\begin{tabular}{llll}
\hline Blade Cost Category & Percent of Cost & Percent from Colorado & Weighted Average \\
\hline Materials & $40.64 \%$ & $\mathbf{5 1 . 3 1 \%}$ & 20.86 \\
\hline Labor & $8.61 \%$ & $100.00 \%$ & 8.61 \\
Burden & $17.64 \%$ & $100.00 \%$ & 17.64 \\
$\begin{array}{l}\text { Sales, general, and } \\
\text { administrative }\end{array}$ & $10.03 \%$ & $100.00 \%$ & 10.03 \\
Engineering & $4.01 \%$ & $0.00 \%$ & 0.00 \\
Logistics & $12.37 \%$ & $25.00 \%$ & 3.09 \\
Profit & $6.69 \%$ & $90.00 \%$ & 6.02 \\
\hline \multicolumn{4}{c}{} \\
\hline
\end{tabular}

\section{Appendix E2. Tower Local Share Calculations}

Table E-3. Percentage of Tower Material Expenditures Spent in Colorado

\begin{tabular}{llll}
\hline Tower Material & Percent of Cost & Percent from Colorado & Weighted Average \\
\hline Weld wire & $1.00 \%$ & $0.00 \%$ & 0.00 \\
Bolts, washers, nuts & $10.00 \%$ & $0.00 \%$ & 0.00 \\
Paint & $8.00 \%$ & $0.00 \%$ & 0.00 \\
\hline Flanges & $18.00 \%$ & $0.00 \%$ & 0.00 \\
Door frame & $1.00 \%$ & $100.00 \%$ & 1.00 \\
Steel plates & $62.00 \%$ & $0.00 \%$ & 0.00 \\
\hline \multicolumn{4}{r}{} \\
\end{tabular}

The percentage of tower material expenditures in Colorado $(1.00 \%)$ is included in the materials cost category in Table E-4 to calculate the percentage of total tower expenditures in Colorado.

Table E-4. Percentage of Total Tower Expenditures Spent in Colorado

\begin{tabular}{llll}
\hline Tower Cost Category & Percent of Cost & Percent from Colorado & Weighted Average \\
\hline Materials & $55.61 \%$ & $\mathbf{1 . 0 0} \%$ & 0.56 \\
Labor & $7.51 \%$ & $100.00 \%$ & 7.51 \\
Burden & $8.10 \%$ & $100.00 \%$ & 8.10 \\
$\begin{array}{l}\text { Sales, general, and } \\
\text { administrative }\end{array}$ & $12.83 \%$ & $100.00 \%$ & 12.83 \\
Engineering & $2.93 \%$ & $0.00 \%$ & 0.00 \\
Logistics & $6.40 \%$ & $25.00 \%$ & 1.60 \\
Profit & $6.62 \%$ & $90.00 \%$ & 5.96 \\
\hline \multicolumn{3}{r}{} \\
\hline
\end{tabular}




\section{Appendix E3. Nacelle Local Share Calculations}

Materials in the nacelles are expected to account for a large majority of the cost, as much as $80 \%$ of the nacelle cost, according to Vestas interviews. This analysis assumes that all materials used to assemble a nacelle are imported from outside Colorado. The percentage of nacelle expenditures in Colorado is assumed to be $0 \%$. Using information collected during Vestas site visits, researchers were able to calculate a percentage of cost, adapting a similar (Global Wind Network 2014) methodology for the calculations in Table E-5.

Table E-5. Percentage of Total Nacelle Expenditures Spent in Colorado

\begin{tabular}{llll}
\hline Tower Cost Category & Percent of Cost & Percent from Colorado & Weighted Average \\
\hline Materials & $80.64 \%$ & $\mathbf{0 . 0 0 \%}$ & 0.00 \\
Labor & $3.30 \%$ & $100.00 \%$ & 3.30 \\
Burden & $3.56 \%$ & $100.00 \%$ & 3.56 \\
$\begin{array}{l}\text { Sales, general, and } \\
\text { administrative }\end{array}$ & $5.65 \%$ & $100.00 \%$ & 5.65 \\
Engineering & $1.29 \%$ & $0.00 \%$ & 0.00 \\
Logistics & $2.82 \%$ & $25.00 \%$ & 0.70 \\
Profit & $2.91 \%$ & $90.00 \%$ & 2.62 \\
\multicolumn{4}{c}{} \\
\hline
\end{tabular}




\section{Appendix F. Full List of Structured Interview Responses}

This appendix lists the questions asked during the structured interviews and percentages of the responses received for each question.

Note: Totals may not sum due to rounding.

1. How would you classify your business? (e.g., hotel, restaurant, grocery store, etc.) $(n=18)$ Reponses cannot be provided for confidentiality reasons.

2. Would you say most of your current customers are:

$\mathbf{5 8 . 3 \%}$ Local (within the nearby cities and counties)

$\mathbf{8 . 3 \%}$ Regional (Eastern Colorado)

$\mathbf{8 . 3 \%}$ From elsewhere in Colorado

$\mathbf{2 5 . 0 \%}$ From out of state

3. Approximately how many years has your business been in operation in this area?

$\mathbf{0 . 0 \%}$ Fewer than 6 months

$\mathbf{0 . 0 \%} 6$ months to 1 year

$\mathbf{5 . 5 \%} 1$ to 5 years

94.4\% More than 5 years

4. What is your job at this business?

$\mathbf{8 3 . 3 \%}$ Owner

$11.1 \%$ Manager

$\mathbf{0 . 0 \%}$ Staff

$\mathbf{5 . 5 \%}$ Other

5. How many employees does your business have?

$38.9 \% 1-5$

$16.7 \% 6-10$

22.2\% $11-15$

16.7\% More than 15

6. Have you hired additional employees since this time last year?

$\mathbf{2 7 . 8 \%}$ Yes (answer questions $6 a, 6 b$, and $6 c$ )

$\mathbf{6 6 . 7 \%}$ No (skip to question 7)

$\mathbf{5 . 5 \%}$ Unsure (skip to question 7)

6a. If yes, how many new employees have been hired? (number)

5 Full time

8 Part time

0 Unsure

0 Prefer not to answer 
6b. Most new employees were hired:

$\mathbf{1 0 0 . 0 \%}$ Locally (within the nearby cities and counties)

$\mathbf{0 . 0 \%}$ Regionally (Eastern Colorado)

$\mathbf{0 . 0 \%}$ From elsewhere in Colorado

$\mathbf{0 . 0 \%}$ From out of state

6c. What do you attribute this additional hiring to? Pick the top two reasons:

$\mathbf{0 . 0 \%}$ Seasonal agricultural workers

$\mathbf{1 1 . 1 \%}$ Regional growth and development

$11.1 \%$ Tourism

$\mathbf{0 . 0 \%}$ Internal operations/changing business model

44.4\% Rush Creek construction

11.1\% Unsure

$\mathbf{2 2 . 2 \%}$ Other

7. Since this time last year, most employees' workloads have:

$\mathbf{5 5 . 5 \%}$ Increased (answer questions $7 a$ and $7 b$ )

$\mathbf{5 . 5 \%}$ Decreased (skip to question 8)

$\mathbf{3 8 . 9 \%}$ Stayed the same (skip to question 8)

$\mathbf{0 . 0 \%}$ Unsure (skip to question 8)

7a. On average, employees are working an additional percent a week:

30.0\% $1 \%-5 \%$

$\mathbf{4 0 . 0} \% 6 \%-10 \%$

$\mathbf{1 0 . 0 \%} 11 \%-20 \%$

$\mathbf{2 0 . 0} \% 21 \%-50 \%$

$\mathbf{0 . 0 \%}$ More than $50 \%$

7b. To what do you attribute this increase in hours worked? Pick the top two reasons:

$\mathbf{2 0 . 0 \%}$ Tourism

$\mathbf{2 0 . 0} \%$ Regional growth and development

$\mathbf{0 . 0} \%$ Seasonal agricultural workers

$\mathbf{4 0 . 0 \%}$ Rush Creek construction

$\mathbf{6 . 7 \%}$ Internal operations/changing business model

$13.3 \%$ Unsure

$\mathbf{0 . 0 \%}$ Other

8. Since this time last year, overall business (revenue) at this establishment has:

11.1\% Significantly increased (answer question 8a)

$\mathbf{5 5 . 5 \%}$ Moderately increased (answer question 8a)

$\mathbf{1 6 . 7 \%}$ Stayed the same (skip to question 9)

$\mathbf{1 1 . 1 \%}$ Moderately decreased (skip to question 9)

$\mathbf{0 . 0 \%}$ Significantly decreased (skip to question 9)

$\mathbf{5 . 5 \%}$ Unsure (skip to question 9) 
8a. To what do you attribute this increase in business (revenue)? Pick the top two reasons:

36.8\% Rush Creek construction

$\mathbf{1 0 . 5 \%}$ Internal operations/changing business model

$\mathbf{1 5 . 8 \%}$ Regional growth and development

$\mathbf{1 5 . 8 \%}$ Tourism

$\mathbf{1 0 . 5 \%}$ Seasonal agricultural workers

$0.0 \%$ Unsure

$10.5 \%$ Other

9. Given current conditions, do you expect to see increases in your business's profitability, sales, or general growth in the next 12 months?

$61.1 \%$ Yes

$16.7 \%$ No

$22.2 \%$ Unsure

10. How would you say your community's economy has changed from this time last year?

$\mathbf{1 6 . 7 \%}$ Strongly improved

$\mathbf{5 0 . 0 \%}$ Slightly improved

$\mathbf{2 7 . 8 \%}$ Stayed the same

$\mathbf{0 . 0 \%}$ Slightly declined

$\mathbf{0 . 0 \%}$ Strongly declined

$\mathbf{5 . 5 \%}$ Unsure

11. Please briefly describe what you attribute this economic change to:

- "Wind and Solar farms"

- "New business in an otherwise downturn"

- "Windfarm and US highway 24 road construction"

- "Not enough housing in Limon for people to move here"

- "We believe as more business and construction companies grow, it's growth everywhere else."

- "Construction projects in the area"

- "Being a rural community with strong agricultural ties, our economy to linked to commodity prices and successful crop production. Some things such as prescriptions, toilet paper, or other necessities are purchased without regard, but large items such as riding lawn mowers or large appliances are usually only purchased when a farmer or rancher has a 'good year'."

- "Positive economic outlook"

- "Mass exodus from the front range to get away from the marijuana grow houses."

12. Are you familiar with the Rush Creek Wind Farm project, which started construction this past spring in your area?

$\mathbf{0 . 0 \%}$ Not at all familiar

$11.1 \%$ Slightly familiar

$16.7 \%$ Somewhat familiar

27.7\% Moderately familiar

44.4\% Extremely familiar 
13. Indicate your level of agreement with the following statement: The development of the Rush Creek Wind Farm has been beneficial to my business.

$\mathbf{3 3 . 3 \%}$ Strongly agree

38.9\% Agree

$\mathbf{2 7 . 8 \%}$ Neutral

$\mathbf{0 . 0 \%}$ Disagree

$\mathbf{0 . 0 \%}$ Strongly disagree

$\mathbf{0 . 0 \%}$ Unsure

14. How do you feel about wind farm development in your community?

$\mathbf{5 0 . 0 \%}$ Strongly support it

$\mathbf{2 2 . 2 \%}$ Moderately support it

$\mathbf{2 7 . 8 \%}$ Neutral

$\mathbf{0 . 0 \%}$ Moderately oppose it

$\mathbf{0 . 0 \%}$ Strongly oppose it

15. Please provide any additional information:

- "I cannot overstate the importance of the rush creek project to Lincoln co or the genoa Co area. For many years our whole region will be impacted positively with the whole nation and world a better place."

- "Has caused housing shortage for locals and increases in rent, causing people to move out of area."

- "We need more projects like this to compensate for decreased oil and gas production."

- "Wind development is great for us during construction."

- "Have supported wind farms. It gives our farms money they can rely on. It keeps some on the farm."

- "Limon needs help to increase housing for when the project is done so your employees have a place to live and raise their families."

- "The farm economy is depressed with commodity prices being low, however the wind farm should help fill in the losses from the agriculture down turn."

- "Need to get with the town to help with housing for people who are going to stay after project is done for the ones that will be staying here for the towers." 